UNIVERSIDADE DE SÃO PAULO

FACULDADE DE ECONOMIA, ADMINISTRAÇÃO E CONTABILIDADE DEPARTAMENTO DE ADMINISTRAÇÃO MESTRADO PROFISSIONAL EM EMPREENDEDORISMO

PLANO DE NEGÓCIOS PARA SPIN-OFF CORPORATIVA

Gabriel Siqueira de Paiva

Orientador: Prof. Dr. Martinho Isnard Ribeiro de Almeida 
Prof. Dr. Marco Antônio Zago Reitor da Universidade de São Paulo

Prof. Dr. Adalberto Americo Fischmann Diretor da Faculdade de Economia, Administração e Contabilidade

Prof. Dr. Roberto Sbragia

Chefe do Departamento de Administração

Prof. Dr. Martinho Isnard Ribeiro de Almeida

Coordenador do Programa de Mestrado Profissional em Empreendedorismo 
GABRIEL SIQUEIRA DE PAIVA

\section{PLANO DE NEGÓCIOS PARA SPIN-OFF CORPORATIVA}

Dissertação apresentada ao Departamento de Administração da Faculdade de Economia, Administração e Contabilidade da Universidade de São Paulo como requisito parcial para obtenção do título de Mestre em Administração.

Orientador: Prof. Dr. Martinho Isnard Ribeiro de Almeida

Versão Corrigida

(versão original disponível na Biblioteca da Faculdade de Economia, Administração e Contabilidade)

SÃO PAULO 


\section{FICHA CATALOGRÁFICA}

Elaborada pela Seção de Processamento Técnico do SBD/FEA/USP

Paiva, Gabriel Siqueira de

Plano de negócios para spin-off corporativa / Gabriel Siqueira de Paiva. - São Paulo, 2016.

$116 \mathrm{p}$.

Dissertação (Mestrado) - Universidade de São Paulo, 2016.

Orientador: Martinho Isnard Ribeiro de Almeida.

1. Empreendedorismo 2. Spin-off corporativa 3. Plano de negócios I. Universidade de São Paulo. Faculdade de Economia, Administração e Contabilidade. II. Título.

CDD -658.421 
Agradeço primeiramente a Deus, pois sem Ele nada seria possível.

Agradeço também ao professor e orientador Martinho, pelo apoio, orientação e paciência durante toda a pesquisa, aos demais professores por compartilharem seu vasto conhecimento e à FEA USP por tudo suporte necessário para conduzir esse trabalho.

Não posso me furtar de lembrar e agradecer a todos os amigos queridos, cujo constante apoio é fundamental na minha vida, em especial: Bruno Leirião, Diego Savegnago, Júlio Cesar Freitas, Cristiano Amadeu, Fernando Gimenez, Karina Bizarria, Ronaldo Rocha, Emmanuel Labastida, Bernardo Serra, Filipe Barros, Débora Rodrigues, Bruno Madureira, Regina Simões, Rodrigo Wanderley, Guilherme Haraguchi, Marcelo Tomei, Maria Regis e Ana Clébia.

Por fim e não menos importante, à minha família, que é a minha maior fonte de inspiração, por quem tudo vale a pena: minha mãe Maria, meu irmão Josemildo, sua esposa Luciana e meus sobrinhos Mateus, Gabriela e Lucas; que são as pessoas mais especiais da minha vida. 

Ao meu pai, que esse ano partiu, mas vive eternamente em meu coração, com seus ensinamentos de humildade, dedicação e amor. 



\section{RESUMO}

Estudo sobre spin-offs corporativas, que tem por objetivo apresentar uma proposta de Plano de Negócio para esse tipo de empresa. Foi elaborado a partir da comparação entre a experiência prática do autor e o disposto na teoria sobre spin-offs corporativas e planos de negócios; e estruturado conforme metodologia de pesquisa para o Mestrado Profissional. Agrega coleta de dados descritiva, estudo de casos, proposição do modelo e validação externa com especialistas no tema. São apresentados dois casos de implantação de spin-offs corporativas em empresas no segmento de turismo no Brasil com descrição dos planos de negócio utilizados em ambas. Foi consultada a teoria sobre spin-off corporativa para correta definição desse tipo de empresa e seus principais aspectos, o que a diferencia de uma spin-off acadêmica, bem como sua relevância para os negócios. Foram também consultados dois planos de negócio teóricos de entidades de incentivo ao empreendedorismo no Brasil e nos Estados Unidos. Após análise comparativa dos quatro planos de negócio e validação com dois especialistas, identificou-se que a relação entre empresa mãe e spin-off é um aspecto crítico desse negócio, bem como a carência de ferramentas para desenho de modelos de negócios. Por fim foi sugerido um padrão de Plano de Negócios para atender as necessidades especificas de implantação de spin-offs corporativas.

Palavras Chave: Empreendedorismo, Spin-off corporativa, Plano de Negócios. 


\begin{abstract}
Research about corporate spin-offs which aims to present a Business Plan model to this kind of company. Was created by the comparison of author's experience and the theory about spin-off and business plan; and was formulated according to the study methodology of the Professional Masters, which combines descriptive data collecting, case studies, a model's proposition and external validation with specialists in this field of knowledge. Are presented two cases of spin-off implementation in brazilian tourism companies with theirs business's plan description. Were consulted the corporate spin-off theory in order to base the precisely definition of this kind of company and its business relevance. Were also consulted theoretical business plan of agencies of entrepreneurship's fostering on Brazil and United States. After comparative analysis of the four business plans and also a specialists's validation, was found that the relationship between the parent firm and the spin-off is an critical aspect of this kind of business as well the lack of tools to draw its business model. Ultimately was proposed a Business Plan model to ensure the specific needs of corporate spin-off implementation.
\end{abstract}

Key Words: Entrepreneurship, Corporate spin-off, Business Plan. 


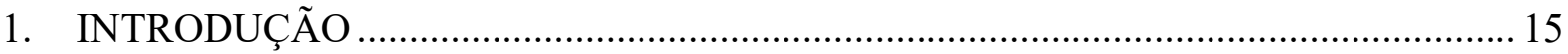

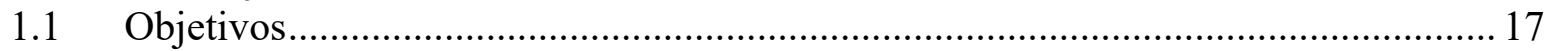

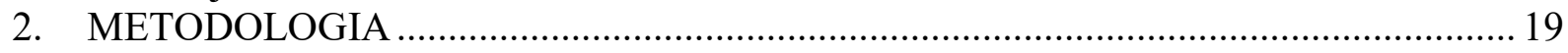

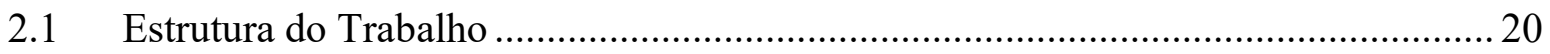

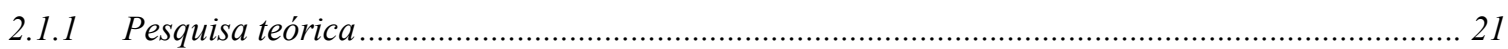

2.1.2 Exposição da Prática - Estudo de Caso ...................................................................................... 22

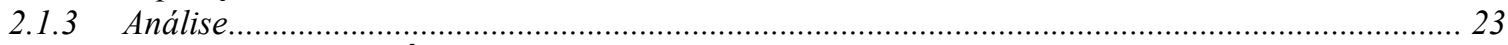

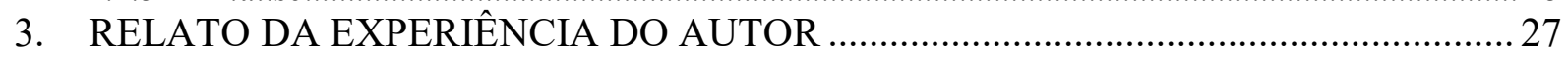

$3.1 \quad$ Estrutura da indústria do turismo no Brasil .............................................................. 27

3.2 Experiência do Autor - projetos de Spin-off corporativa em empresa de Turismo ... 30

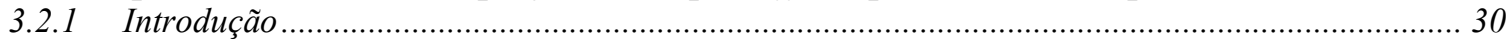

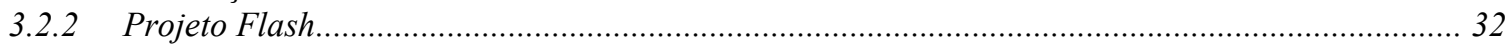

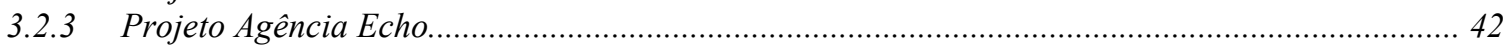

4. REFERENCIAL TEÓRICO ………………………………………………..... 51

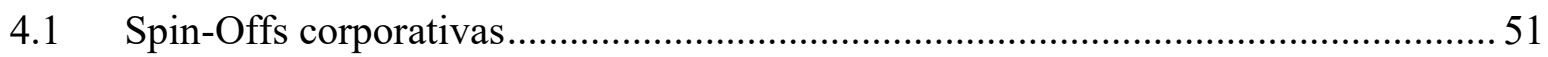

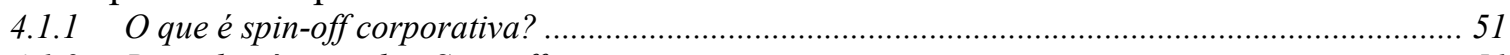

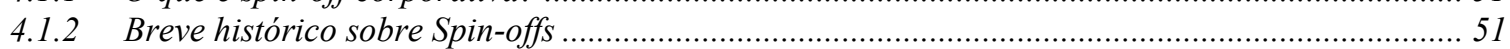

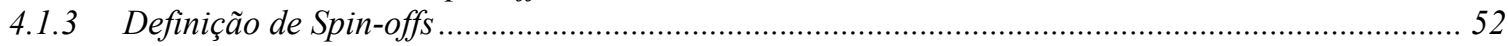

4.1.4 Diferença Entre Spin-offs Corporativas E Acadêmicas........................................................... 54

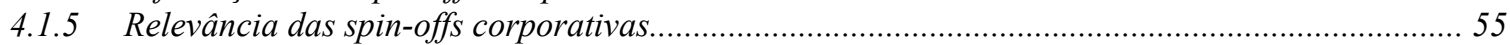

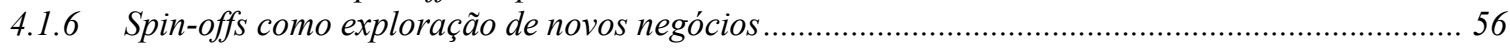

4.1.7 A Relação entre spin-off e empresa mãe e............................................................................. 60

4.2 Modelos de planejamento de Novos Negócios................................................................ 64

4.2.1 Resumo dos modelos de planejamento de novos negócios.....................................................65

4.2.2 Explicą̧ão dos itens dos modelos ......................................................................................... 66

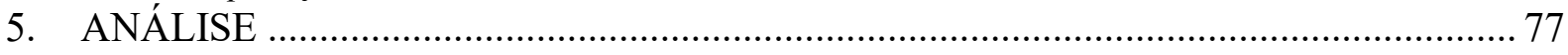

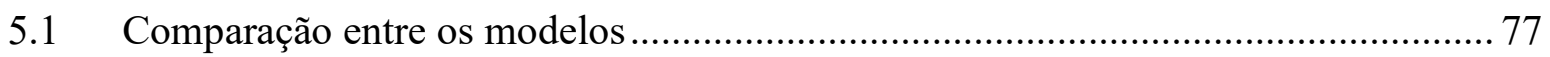

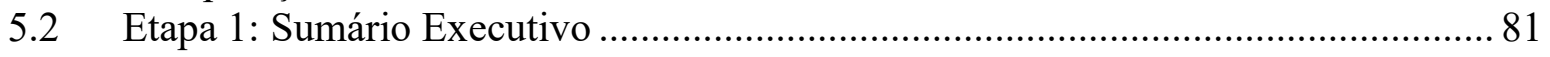

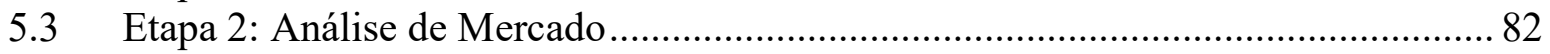

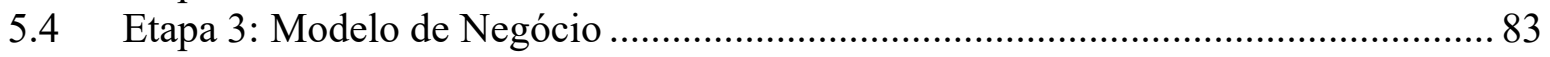

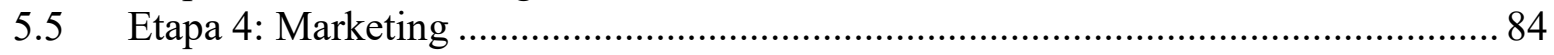

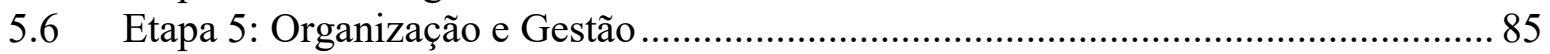

5.7 Etapa 6: Governança.......................................................................................... 85

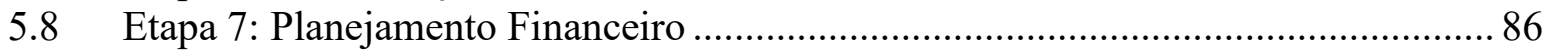

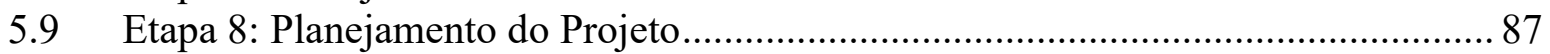

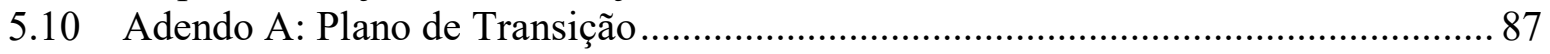

5.11 Adendo B: Avaliação Estratégica....................................................................... 88

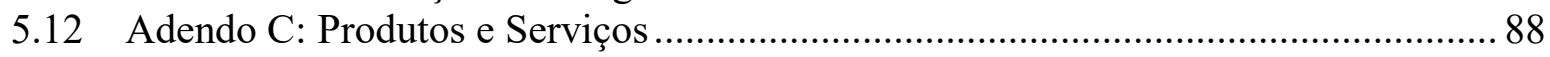

5.13 Proposta de Modelo de Plano de Negócios para Spin-Off Corporativas ................... 89

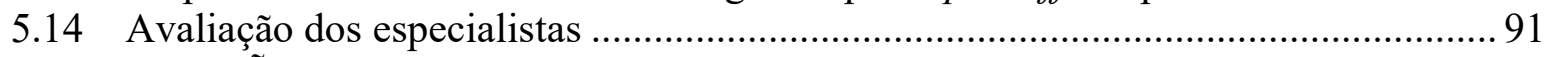

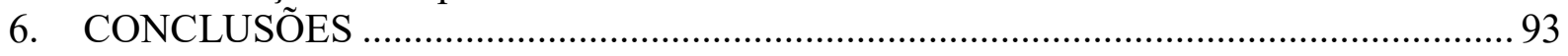

6.1 Proposta de modelo de Plano de Negócios para Spin-Offs Corporativas - ajustada. 93

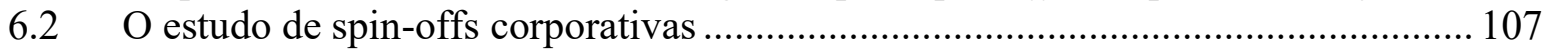

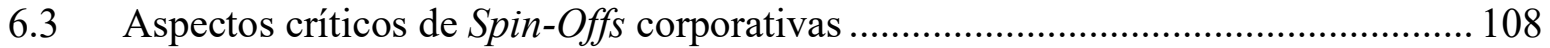

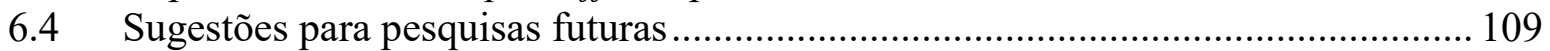

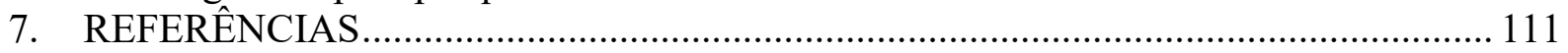

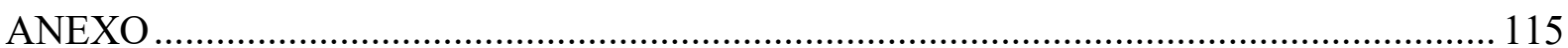




\section{LISTA DE ILUSTRAÇÕES}

Ilustração 1 - Ciclo da aprendizagem experimental .............................................................22

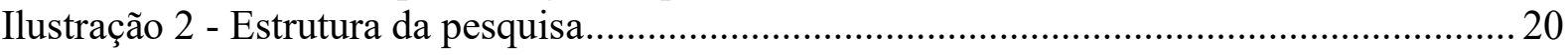

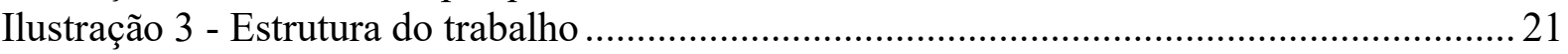

Ilustração 4 - Estrutura da indústria do Turismo no Brasil ....................................................2 29

Ilustração 5 - Posição das spin-offs estudadas na cadeia do turismo ......................................... 32

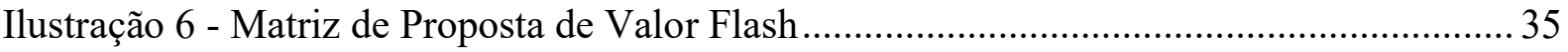

Ilustração 7 - BMG Canvas do Projeto Flash................................................................................ 37

Ilustração 8 - Estrutura do Projeto Flash............................................................................... 40

Ilustração 9 - BMG Canvas Agência Echo .............................................................................. 45

Ilustração 10 - Governança Corporativa - Agência Echo ........................................................... 46

Ilustração 11 - Estrutura do projeto Echo...………………………………………………... 50

Ilustração 12 - Estratégias de Crescimento .............................................................................57

Ilustração 13 - Agrupamento dos itens dos modelos para análise.............................................. 80

Ilustração 14 - Proposta de Modelo de Plano de Negócios para spin-offs corporativas........... 90

Ilustração 15 - Proposta de modelo de Plano de Negócios para Spin-Offs corporativas ......... 96

Ilustração 16 - Guia de preenchimento: Alinhamento Estratégico ..............................................97

Ilustração 17 - Guia de Preenchimento: Análise Competitiva .................................................. 98

Ilustração 18 - Guia de Preenchimento: Modelo de Negócio (lâmina 1 de 2) ......................... 99

Ilustração 19 - Guia de Preenchimento: Modelo de Negócio (lâmina 2 de 2) ........................ 100

Ilustração 20 - Guia de Preenchimento: Marketing ............................................................ 100

Ilustração 21 - Guia de Preenchimento: Organização e Gestão ……………………………..... 101

Ilustração 22 - Guia de preenchimento: Governança ............................................................ 102

Ilustração 23 - Guia de preenchimento: Planejamento Financeiro (lâmina 1 de 2) ................ 103

Ilustração 24 - Guia de preenchimento: Planejamento Financeiro (lâmina 2 de 2) ................ 104

Ilustração 25 - Guia de Preenchimento: Planejamento do Projeto (lâmina 1 de 2) ................ 105

Ilustração 26 - Guia de Preenchimento: Planejamento do Projeto (lâmina 2 de 2) ................ 106 


\section{LISTA DE TABELAS}

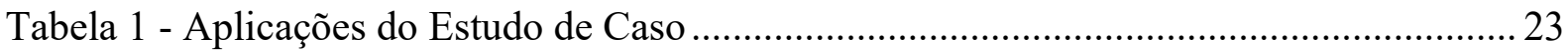

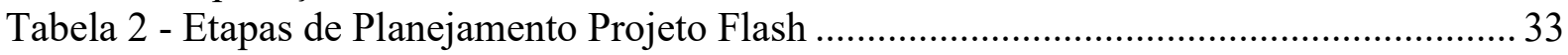

Tabela 3 - Estrutura do Plano de Implantação Echo .................................................................. 42

Tabela 4 - Compartilhamento de Processos: Agência Echo ......................................................... 47

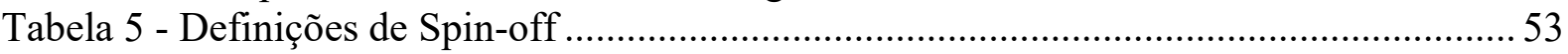

Tabela 6 - Diferença entre spin-offs corporativas e acadêmicas...............................................55

Tabela 7 - Mecanismos de Ingresso em um novo negócio ...................................................59

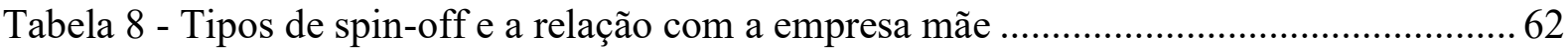

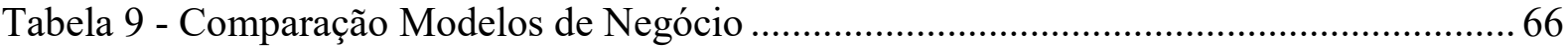

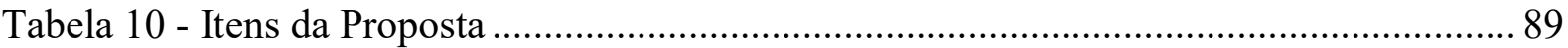





\section{INTRODUÇÃO}

A criação de novos negócios (ou empreendedorismo) é um dos elementos mais importantes da nossa sociedade capitalista. Por meio de novas empresas é que são gerados o maior volume de novos empregos, novas tecnologias são criadas e é dado a oportunidade de qualquer indivíduo se tornar dono do seu próprio negócio; o empreendedorismo é, portanto, um dos aríetes da liberdade econômica e social, experimentada por muitas nações ao longo dos séculos.

A Organização para Cooperação e Desenvolvimento Econômico (OECD) enfatiza a importância do empreendedorismo ao afirmar que:

A criação de novos negócios e contração ou saída dos menos produtivos são elementos chave na dinâmica da Economia. Novas empresas atraem recursos para novas atividades, e quando prosperam, são capazes de criar um número expressivo de novos empregos. (OECD, 2004, p. 8).

A forma mais comum de criação de novos negócios, é aquela realizada por indivíduos que, por motivações diversas que não fazem parte do escopo do presente trabalho, decidem investir seus recursos na criação de uma nova empresa, passando a ser considerados empresários.

Uma outra forma de empreendedorismo menos visível é aquela realizada por empresas já consolidadas, tais empresas também podem executar ações empreendedoras, inclusive a criação de novos negócios e de empresas independentes, a essa segunda ação - criação de empresas independentes - é dado o nome de Spin-off.

Em 2014, o autor deste estudo, profissional com dez anos em gestão de projetos, teve a oportunidade de conduzir um projeto de implantação spin-off onde atuou desde o planejamento até a sua entrega. Na ocasião, constitui-se como seu primeiro projeto dessa natureza.

Após 18 meses, o autor gerenciou um novo projeto de spin-off corporativa. Na ocasião, contou com a sua experiência do primeiro projeto e aprimorou o Plano de Negócios previamente utilizado. Esse contato com o tema de spin-off corporativa o motivou a pesquisar o tema para entender: como seria um bom Plano de Negócios para uma spin-off corporativa? 
Tendo essa inquietação como pano de fundo, foi desenvolvido esse trabalho que está estruturado nas seguintes seções:

1) Descrição da experiência

A principal motivação do autor para pesquisar sobre o fenômeno de spin-off corporativa, foi decorrente da sua experiência de mais de 8 anos com gestão de projetos estratégicos e, mais especificamente, na condução do planejamento de 2 projetos de spin-off.

Sua experiência foi realizada durante a implantação de novas empresas no segmento de turismo, ocorrido entre 2014 e 2015, onde atuou como o gerente responsável pelo planejamento e implantação dessas empresas.

\section{2) Pesquisa Teórica}

Parte-se da consulta de trabalhos sobre spin-off e planejamento de novos negócios. O autor compreende que esses dois temas são os mais aderentes ao estudo em questão e sua a junção cria um recorte específico, atraente e pouco explorado, porém, de grande relevância tanto em termos acadêmicos como profissionais.

\section{3) Análise}

Mediante comparação das experiências com a pesquisa teórica, o autor espera contribuir ao estudo das spin-off corporativos e, principalmente, apresentar mecanismos que promovam e facilitem a gestão de projetos dessa natureza; contribuindo de maneira direta na prática empreendedora.

É importante pontuar que o escopo desse trabalho é limitado ao universo de spin-offs enquanto das necessidades para sua implantação. Portanto, não faz parte do escopo, o estudo dos conceitos, etapas e ferramentas que levam uma empresa a decidir criar um novo negócio em formato de spin-off.

Ou seja, é abordado o fenômeno após a tomada a decisão de criação da spin-off, sendo necessário, portanto a execução de sua implantação. De modo que, na visão do autor, o Plano de Negócios, é uma ferramenta para basear tal execução. 


\subsection{Objetivos}

Face o contexto exposto acima, o presente trabalho tem como objetivos:

Principal:

Propor um modelo de Plano de Negócios para spin-off corporativa.

Secundários:

(i) sistematizar a experiência do autor com a elaboração de Planos de Negócio para spin-off corporativas.

(ii) subsidiar o trabalho mediante pesquisa teórica de trabalhos e conceitos inerentes ao planejamento de spin-offs corporativas, bem como modelos de planejamento das agências SEBRAE e SBA.

(iii) relacionar os resultados da pesquisa teórica com a experiência do autor para apresentar uma proposta de modelo de Plano de Negócios de spin-off corporativa.

(iv) validar a mencionada proposta de Plano de Negócios com especialistas em planejamento. 


\section{METODOLOGIA}

O presente trabalho foi desenvolvido a partir da premissa principal do Mestrado Profissional que propõe analisar os objetos de estudo a partir da experiência prática do autor, para então abordá-los sob a perspectiva teórica; invertendo assim o fluxo tradicional de pesquisa que parte da teoria para então chegar à prática. (KRAKAUER et al, 2015).

Essa forma de criação do conhecimento, atende ao principal objetivo do Mestrado Profissional que é a contribuição efetiva com o setor produtivo nacional - quer seja ele privado ou público - mediante a articulação entre conhecimento atualizado, metodologias pertinentes e aplicação orientada à prática. De modo que o trabalho final do curso pode ser apresentado em diversos formatos, entretanto, precisa necessariamente estar vinculado a problemas reais da área de atuação do profissional-pesquisador (CAPES, 2014).

Tal forma de estruturar o conhecimento gerado busca enfatizar a experiência prática dos estudantes e pesquisadores dos mestrados profissionais, mantendo, porém, o zelo e o rigor da pesquisa acadêmica. É, portanto, uma forma de criar conhecimento que mescla aspectos das duas realidades: profissional e acadêmica.

Com base no disposto acima, o presente trabalho segue estrutura de pesquisa adaptada da Teoria de Aprendizagem Experimental ${ }^{1}$ de Kolb, que apresenta um ciclo onde o aprendizado começa na experiência concreta, segue para a observação reflexiva, passa pela contextualização abstrata e é concluído na experimentação ativa. Ao ser finalizado, o ciclo serve como um guia para a criação de novas experiências. (KRAKAUER, 2014).

Visualmente o ciclo do aprendizado fica da seguinte maneira, conforme apresentado na ilustração 1:

\footnotetext{
${ }^{1}$ ELT - Experimental Learning Theory.
} 


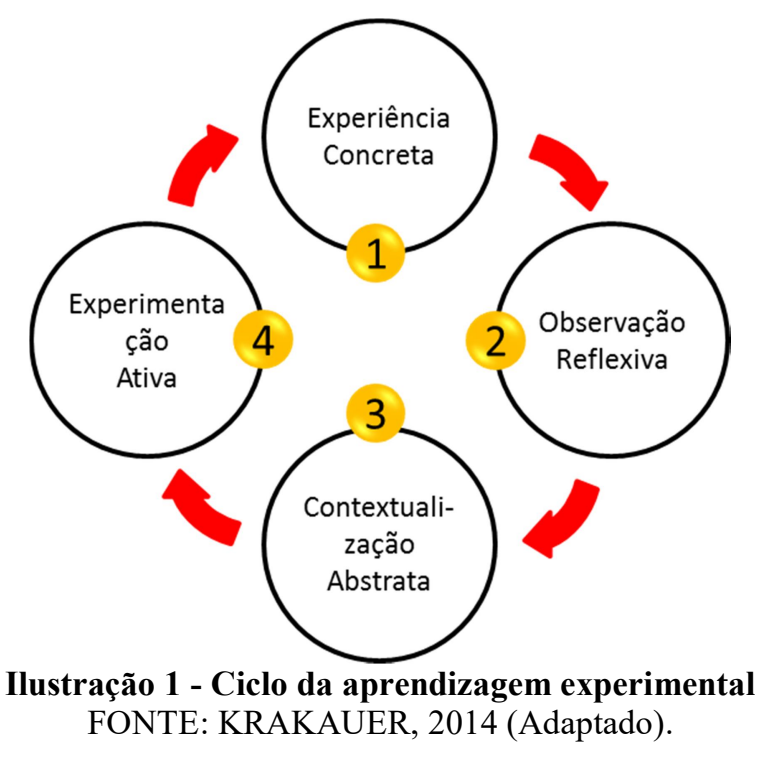

Considerando a adaptação ao presente trabalho, cujo objetivo principal é apresentar um modelo de Plano de Negócios para spin-offs corporativas, o ciclo dessa pesquisa não prevê a etapa de experimentação ativa (número 4), sendo, portanto, limitado a três passos, conforme ilustração 2 abaixo:

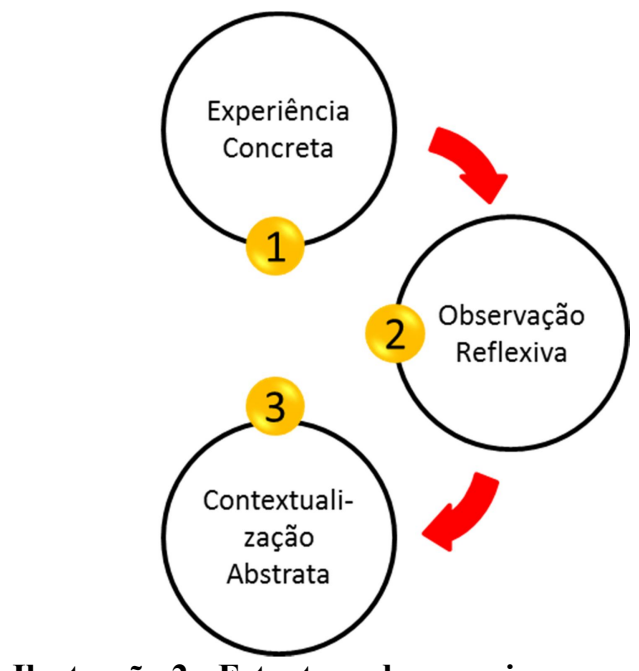

Ilustração 2 - Estrutura da pesquisa

\subsection{Estrutura do Trabalho}

A ilustração 3 é um diagrama elaborado pelo próprio autor que busca demonstrar, de forma visual simplificada, a estrutura proposta para o trabalho. 


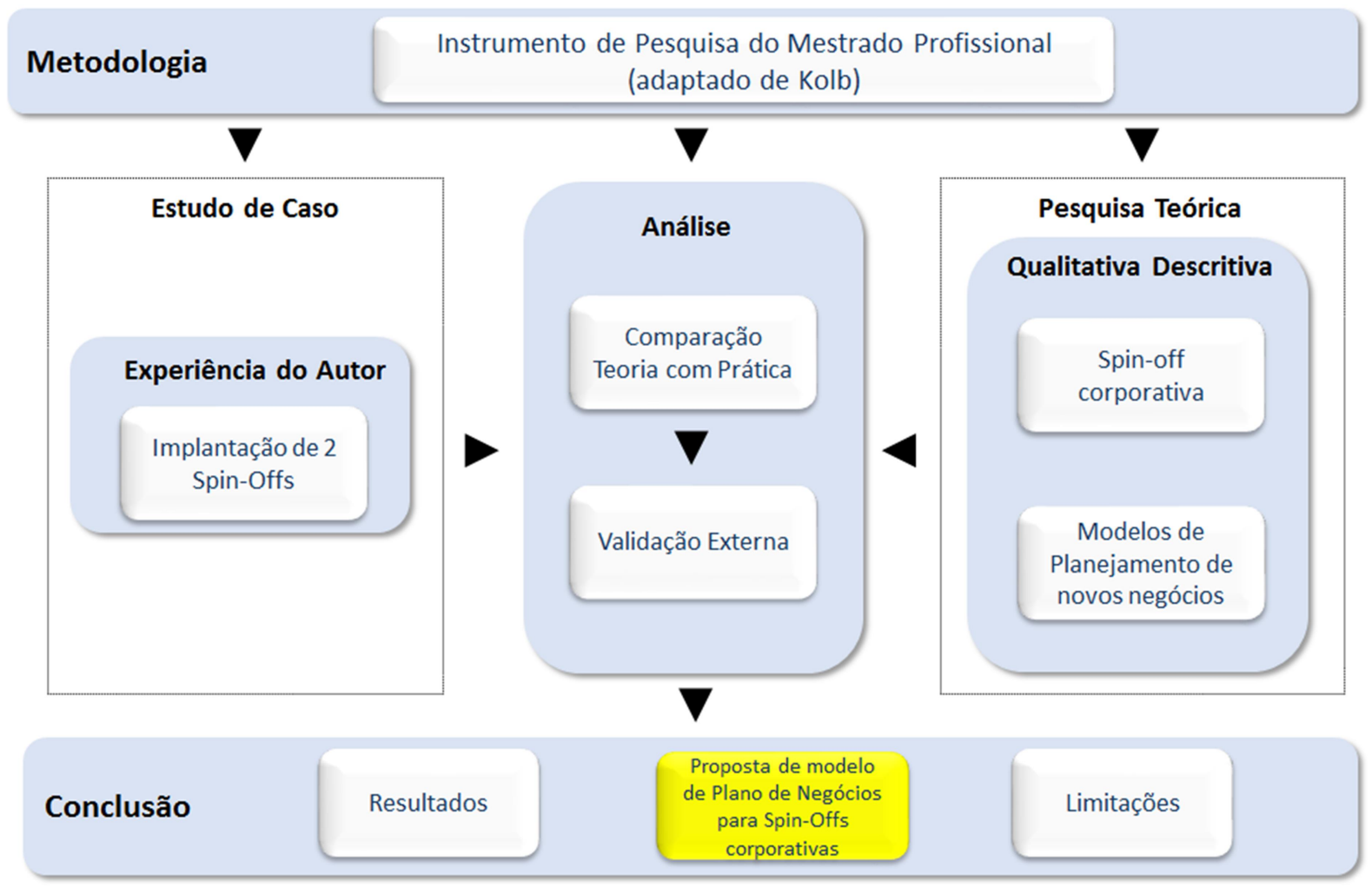

Ilustração 3 - Estrutura do trabalho

\subsubsection{Pesquisa teórica}

Para o estudo teórico foi desenvolvida uma pesquisa qualitativa, que em relação aos seus objetivos, se caracterizou por ser descritiva. Gil (2002, p. 42) define este tipo de pesquisa como sendo aquela que "visa descrever as características de determinada população ou fenômeno ou o estabelecimento de relações entre variáveis". De modo que no presente estudo, os principais objetivos da pesquisa teórica foram:

1) Descrever e contextualizar o que é Spin-off corporativa

2) Apresentar modelos de planos de novos negócios que tenham aderência ao problema proposto.

Tal abordagem é corroborada por Goldenberg (2011) quando afirma que a representatividade dos dados na pesquisa qualitativa em ciências sociais está relacionada a sua capacidade de possibilitar a compreensão do significado e a "descrição densa" dos fenômenos estudados em seus contextos e não a sua expressividade numérica. 
Foi executada mediante Pesquisa Bibliográfica que "busca conhecer, analisar e explicar contribuições sobre determinado assunto, tema ou problema, com base em referências publicadas em vários tipos de fontes” (MARTINS; TEÓPHILO, 2009, p. 54).

\subsubsection{Exposição da Prática - Estudo de Caso}

Para exposição da prática do autor na criação de spin-offs corporativas foi escolhido o método de Estudo de Caso; adaptado, porém, à realidade do Mestrado Profissional.

Tal adaptação se faz necessária, pois de acordo com Martins e Teóphilo (2009) o pesquisador de um estudo de caso, deve ser uma figura externa ao fenômeno estudado, apesar de deter profundo conhecimento teórico sobre o mesmo. Entretanto, considerando a premissa do mestrado profissional de iniciar a investigação a partir da experiência prática do autor, é feito tal adaptação ao estudo de caso.

Essa adaptação é possível, justamente pela flexibilidade que o Estudo de Caso apresenta quando das técnicas utilizadas em sua construção, conforme afirma Goldenberg "não é possível formular regras precisas sobre as técnicas utilizadas em um estudo de caso porque cada entrevista ou observação é única: depende do tema, do pesquisador, e de seus pesquisados". (GOLDENBERG, 2011, p. 34).

A escolha do Estudo de Caso no presente trabalho, surge da complexidade envolvida no planejamento de criação de uma nova empresa. Este fenômeno exige a condução de diversas atividades, com múltiplas pessoas, tarefas e interconexões que envolvem não só os atores internos ao projeto, como também pessoas e entidades externas.

Segundo Yin (2010), a necessidade do uso de Estudo de Caso surge do desejo de entender fenômenos sociais complexos. Uma vez que o Estudo de Caso permite aos pesquisadores entender as características holísticas dos acontecimentos da vida real como por exemplo processos organizacionais e administrativos.

Além da complexidade do fenômeno Yin (2010) apresenta outros elementos que corroboram para a adoção do estudo de caso. Dado a pergunta de pesquisa iniciar com "Como" (Como 
seria um bom modelo de Plano de Negócios para uma Spin-off Corporativa?), o mesmo autor argumenta que o Estudo de Caso se apresenta como o mais indicado, pois:

As questões "como" e "por que" são mais explanatórias e levam ao uso de estudo de caso, pesquisas históricas e experimentos como métodos de pesquisas preferidos. Isso ocorre porque essas questões lidam com os vínculos operacionais que necessitam ser traçados ao longo do tempo, mais do que as meras frequências ou incidências. (YIN, 2010, p. 30).

Além da ligação com a questão de pesquisa, Yin (2010) apresenta quatro aplicações para o estudo de caso. A tabela abaixo, traz as aplicações apresentadas por Yin com uma marcação de aderência aos casos estudados no presente trabalho.

Tabela 1 - Aplicações do Estudo de Caso

\begin{tabular}{|l|c|}
\hline \multicolumn{1}{|c|}{ Aplicação segundo Yin } & $\begin{array}{c}\text { Aderência à essa } \\
\text { pesquisa }\end{array}$ \\
\hline $\begin{array}{l}\text { Explicar vínculos causais em intervenções da vida real que sejam complexos } \\
\text { para estratégias de levantamento ou experimentais }\end{array}$ & SIM \\
\hline Descrever uma intervenção e o contexto da vida real em que ela ocorreu & SIM \\
\hline Ilustrar determinados tópicos em uma avaliação em modo descritivo & SIM \\
\hline $\begin{array}{l}\text { Explorar situações onde a intervenção sendo avaliada não possui um único e } \\
\text { claro conjunto de resultados }\end{array}$ & SIM \\
\hline
\end{tabular}

Fonte: adaptado de Yin (2010)

$\mathrm{O}$ autor descreve a sua experiência em duas implantações de spin-off (empresas FLASH e ECHO) na mesma empresa (ALPHA), de modo que a pesquisa pode ser classificada como estudo de caso múltiplos. Yin (2010) argumenta que esse tipo de abordagem é aconselhado quando o pesquisador procura identificar replicações literais dos fenômenos estuados; no presente trabalho, o fenômeno replicado foi a implantação de duas spin-offs corporativas pelo mesmo executivo, na mesma empresa e em condições de planejamento semelhantes.

\subsubsection{Análise}

Considerando novamente a premissa do Mestrado Profissional em relacionar a experiência do autor com a teoria no intuito de criar contribuição prática, a etapa de análise desse trabalho busca justamente comparar a prática do autor com a teoria, para então propor um modelo. Tal abordagem está em linha com Yin (2010) que argumenta que o estudo de caso pode ser usado para determinar se as proposições da teoria são corretas ou se existem explicações alternativas 
mais relevantes. "Dessa maneira o caso único pode representar uma contribuição significativa para a formação do conhecimento e da teoria”. (YIN, 2010, p. 71).

Para validar a análise teoria $\mathrm{x}$ prática, e considerando que não faz parte do presente trabalho a experimentação ativa dos achados (conforme Ilustração 2 acima), foi escolhido submeter a pesquisa para avaliação de especialistas em Planejamento. Tal abordagem é definida por Yin (2010) como Validade Externa que visa saber se as descobertas do estudo podem ser aplicadas de forma genérica a outras situações.

Os especialistas escolhidos foram:

(i) Marcelo Caldeira Pedroso: professor do Departamento de Administração da Faculdade de Economia, Administração e Contabilidade (FEA) da Universidade de São Paulo (USP). Coordenador do Núcleo de Estudos Estratégicos no Setor de Saúde (FEA-USP) e do Programa de Estudos em Saúde da Fundação Instituto de Administração (FIA). É doutor em ciências pelo Departamento de Medicina Preventiva da Faculdade de Medicina (USP). É doutor, mestre e graduado em engenharia de produção pela Escola Politécnica (USP). Possui pós-doutorado em administração na FEA-USP. Possui experiência executiva anterior em serviços de consultoria (Deloitte, Ernst Young Consulting, IBM, i2 Technologies, KPMG Consulting/BearingPoint, TerraForum) e saúde (Grupo Fleury).

(Fonte: CNPQ - Plataforma Lattes, 2016)

(ii) Marcos Hashimoto: Doutor em Administração de Empresas pela EAESP/FGV (AACSB), linha de pesquisa em Empreendedorismo Corporativo. Mestre em Administração de Empresas pela EAESP/FGV. Tecnólogo em Processamento de Dados pelo Instituto Presbiteriano Mackenzie. Tem também Especialização em Planejamento Empresarial pela Univ. São Judas Tadeu, Licenciatura Plena pelo Instituto Presbiteriano Mackenzie e PósGraduação em Análise de Sistemas pelo Instituto Presbiteriano Mackenzie. Atualmente é docente permanente e líder da linha de empreendedorismo do Mestrado Profissional em Administração de Empresas da Faculdade Campo Limpo Paulista. Membro do Núcleo de Pesquisa em Empreendedorismo da Fundação Dom Cabral e do Instituto Empreender Endeavor.

(Fonte: CNPQ - Plataforma Lattes, 2016) 
A validação foi realizada mediante o envio da proposta de modelo aos especialistas por e-mail e, de acordo com a disponibilidade de agenda dos mesmos, uma conversa presencial onde o autor perguntou aos especialistas se eles validavam a proposta e que recomendações consideravam pertinentes.

No caso do Prof ${ }^{0}$ Marcelo Caldeira Pedroso, foi possível a entrevista, que foi realizada em seu escritório na Universidade de São Paulo, no dia 18/07/2016 às 17:30.

O Prof ${ }^{\mathrm{o}}$ Marcos Hashimoto, por limitação de tempo e agenda, emitiu o parecer de sua avaliação por e-mail, o qual inclusive encontra-se na seção de anexos do presente trabalho, vide anexo A. 


\section{RELATO DA EXPERIÊNCIA DO AUTOR}

\subsection{Estrutura da indústria do turismo no Brasil}

A cadeia do turismo brasileira é composta pelos seguintes integrantes:

- Agências de Turismo: Empresas (em geral de pequeno e médio porte) que representam o principal canal de comunicação e distribuição dos produtos de turismo. Podem se subdividir em dois tipos:

Agências "Tradicionais": são lojas físicas, podendo ser encontradas em qualquer região de cidades dos mais diversos portes. Tem por característica um processo de vendas extremamente manual, pessoal e consultivo. Apresentam grande pulverização e baixa formalidade; têm, portanto, baixíssimo poder de barganha na cadeia.

Agências On-Line ou $O T A^{2}$ : São lojas virtuais de vendas dos produtos de turismo. A venda é totalmente automatizada com baixo nível de consultoria, são responsáveis pela venda em grandes volumes, de modo que possuem alto nível de barganha na cadeia.

- Fornecedores: Hotéis, companhias aéreas, locadoras de veículo, seguradoras, empresas de entretenimento e empresas de eventos.

- Consolidadoras e Operadoras: As operadoras são empresas que atuam como intermediários na cadeia do turismo; são essencialmente $\mathrm{B}^{2} \mathrm{~B}^{3}$, porém algumas podem atuar também como $B 2 C^{4}$. Sua principal função é integrar os serviços dos fornecedores (hotéis, companhias aéreas, locadoras de carro, empresas de transporte terrestre, ingressos, etc.) aos clientes; configurando um importante elemento de viabilidade e expansão dos negócios em ambas as

\footnotetext{
${ }^{2}$ OTA - Sigla de língua inglesa para On-Line Travel Agency - que em português significa Agência de Viagens On-Line.

${ }^{3}$ B2B - Sigla de língua inglesa para Business to Business - que em português significa o segmento de empresas que tem como clientes outras empresas.

${ }^{4} \mathrm{~B} 2 \mathrm{C}$ - Sigla de língua inglesa para Business to Consumer - que em português significa o segmento de empresas que tem como clientes o consumidor final.
} 
pontas. Tal importância se dá pela impossibilidade das duas pontas da cadeia se integrar de maneira eficiente.

Para exemplificar vamos imaginar um hotel em Pittsburgh, Estados Unidos, que possui 150 quartos disponíveis em sua propriedade. Se fosse contar apenas com sua força própria de divulgação e vendas precisaria de uma quantidade expressiva de pessoas para conseguir promover o seu estabelecimento além dos limites da cidade; seria menos provável ainda que conseguisse extrapolar os limites do seu país e ser uma opção de hospedagem para alguém em São José dos Campos no Brasil. De tal modo que agindo de maneira autônoma, certamente teria problemas para comercializar de maneira eficiente todos os seus quartos.

Ao mesmo tempo, se uma agência em São José dos Campos precisasse de um quarto de hotel em Pittsburgh, não o conseguiria reservar sem antes o pagamento prévio de pelo menos uma parte da estadia. Mesmo que a agência tenha condições econômicas de arcar com tal prépagamento, o risco financeiro é elevado, pois caso o viajante (cliente da agência) desista da reserva, a agência perderia o dinheiro previamente alocado.

A operadora atua intermediando a relação entre diversos fornecedores e clientes. Serve como um propagador de produto e ampliador do canal de vendas (para os fornecedores) e como canal de obtenção de produto para os clientes.

Dado sua natureza de intermediário, os principais diferenciais competitivos de uma operadora estão sustentados em três fatores/processos principais:

(i) Capacidade de negociação junto aos fornecedores: para obter conteúdo relevante, a preços competitivos e com variedade de locais.

(ii) Distribuição: quanto mais clientes uma operadora tiver, melhor a sua capacidade de vendas e consequentemente de distribuir produtos, aumentando seu poder de barganha junto aos fornecedores.

(iii) Infraestrutura tecnológica: a integração entre diversos atores, bem como o expressivo volume de transações exigem que as operadoras tenham sob sua gestão poderosas plataformas tecnológicas e processos robustos para suportar tal operação.

- Brokers: São consolidadoras de produtos internacionais; primordialmente hotéis. 
Atuam da mesma forma que as consolidadoras nacionais, porém com acesso a um expressivo número de hotéis ao redor do mundo. A grande diferença entre os brokers e os consolidadores nacionais é que os primeiros atuam tanto como B2B, quanto $\mathrm{B} 2 \mathrm{C}$.

- Clientes Finais: É o comprador do produto de turismo, podem ser tantas pessoas físicas quanto jurídicas. Até poucos anos atrás era um agente passivo da cadeia; porém com a facilidade de acesso a informações (e produtos direto com fornecedores e brokers) tem aumentado significativamente seu poder de barganha. Podem ser divididos em duas categorias: Lazer e Corporativo.

Em resumo, da indústria do Turismo pode ser representada pela ilustração 4 abaixo:

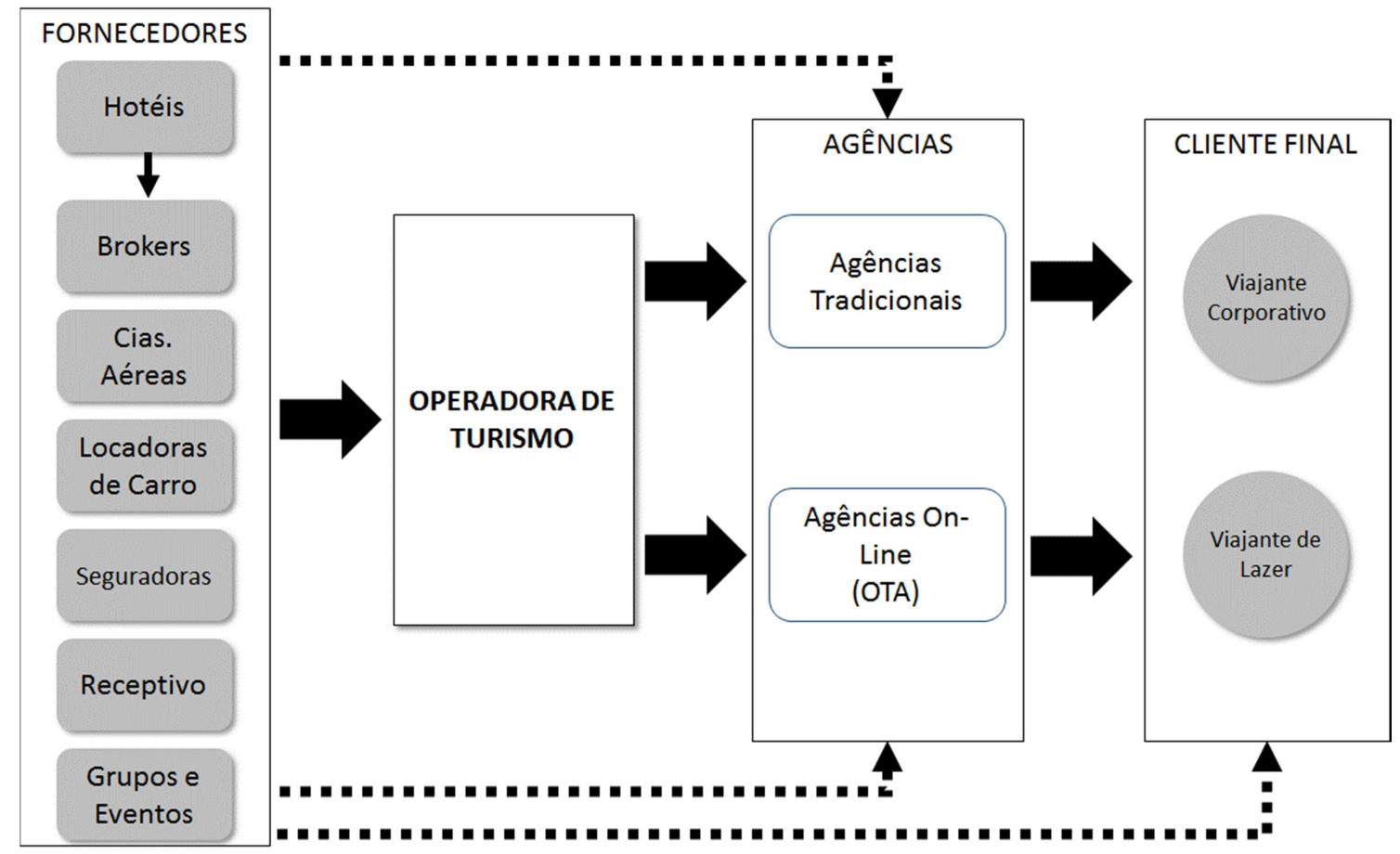

Ilustração 4 - Estrutura da indústria do Turismo no Brasil

As formas de contratação on-line têm tomado espaço cada vez mais significante. Em 2012 a empresa de consultoria comScore, que é líder em medições do mundo digital, divulgou os resultados da pesquisa que mostra sobre o mercado online de turismo no Brasil. De acordo com seu executivo sênior, Alex Banks o estudo, 16,5 milhões de brasileiros visitaram sites de turismo em julho 2012, 18\% a mais que no ano anterior. (BANKS, 2012) 
No Brasil, o turismo é uma das indústrias mais dinâmicas e que tem recebido especial atenção nos últimos tempos, em virtude dos megaeventos como a Copa do Mundo de Futebol de 2014 e as Olimpíadas que serão no Rio de Janeiro em 2016.

Quando se observa a cadeia do turismo à época da execução do presente trabalho, têm-se um cenário de grandes mudanças em termos de operação e posicionamento de mercado, principalmente nos canais de comercialização hoteleira.

Essas mudanças têm origem no advento de novas tecnologias mais baratas, que permitem a integração de toda cadeia de serviços de maneira rápida e simples. Consequentemente, novos entrantes conseguem se posicionar de maneira agressiva na oferta de produtos com preços baixos. Tais entrantes se caracterizam em um grande desafio para empresas mais tradicionais no mercado.

\subsection{Experiência do Autor - projetos de Spin-off corporativa em empresa de Turismo}

\subsubsection{Introdução}

Conforme mencionado anteriormente, o autor deste estudo teve a oportunidade de conduzir o planejamento de duas spin-offs no segmento de turismo. Ambas empresas foram originadas a partir de uma operadora de turismo, na qual o autor fazia parte do quadro de colaboradores na época da pesquisa.

Por questões de preservação e segurança dos negócios das empresas, os nomes das mesmas serão mantidos em sigilo e, portanto, os nomes utilizados são fictícios.

A Operadora de Turismo supramencionada, será chamada de Empresa ALPHA. Essa empresa é uma das maiores Operadoras de Turismo da América Latina e tem como foco de negócios o segmento de viagens corporativas e de lazer. Possui capital privado, 24 anos de mercado, sede em São Paulo, com 20 filiais distribuídas pelo Brasil e atualmente conta com mais de 700 funcionários. 
Entre 2012 e a época de elaboração dessa pesquisa o autor atuou como o principal Gerente de Planejamento da empresa, tendo participação direta nos dois casos descritos, conforme abaixo:

CASO 1 - FLASH: A Flash foi uma empresa criada pela Empresa ALPHA em 2014 para atuar no mesmo segmento da empresa mãe (operadora de turismo B2B), fornecendo seus produtos e serviços para agências de viagem que buscavam opções mais baratas que àquelas fornecidas pela Empresa Alpha e cuja gama de serviços ofertada não tinha aderência com suas necessidades.

CASO 2 - AGÊNCIA ECHO - Criada em 2015, a agência Echo foi uma empresa criada em sociedade com um dos principais clientes da Empresa ALPHA com o objetivo de atender pequenas e médias empresas e profissionais liberais em suas necessidades de viagem. A oportunidade foi apresentada à Empresa Alpha por esse sócio, que é uma das líderes no atendimento a grandes clientes corporativos no Brasil e que identificou esse nicho de mercado pouco explorado pelas agências de viagens.

Para facilitar o entendimento, a ilustração 5 abaixo demonstra em que parte da cadeia do turismo se encontra cada uma das spin-offs mencionadas. 


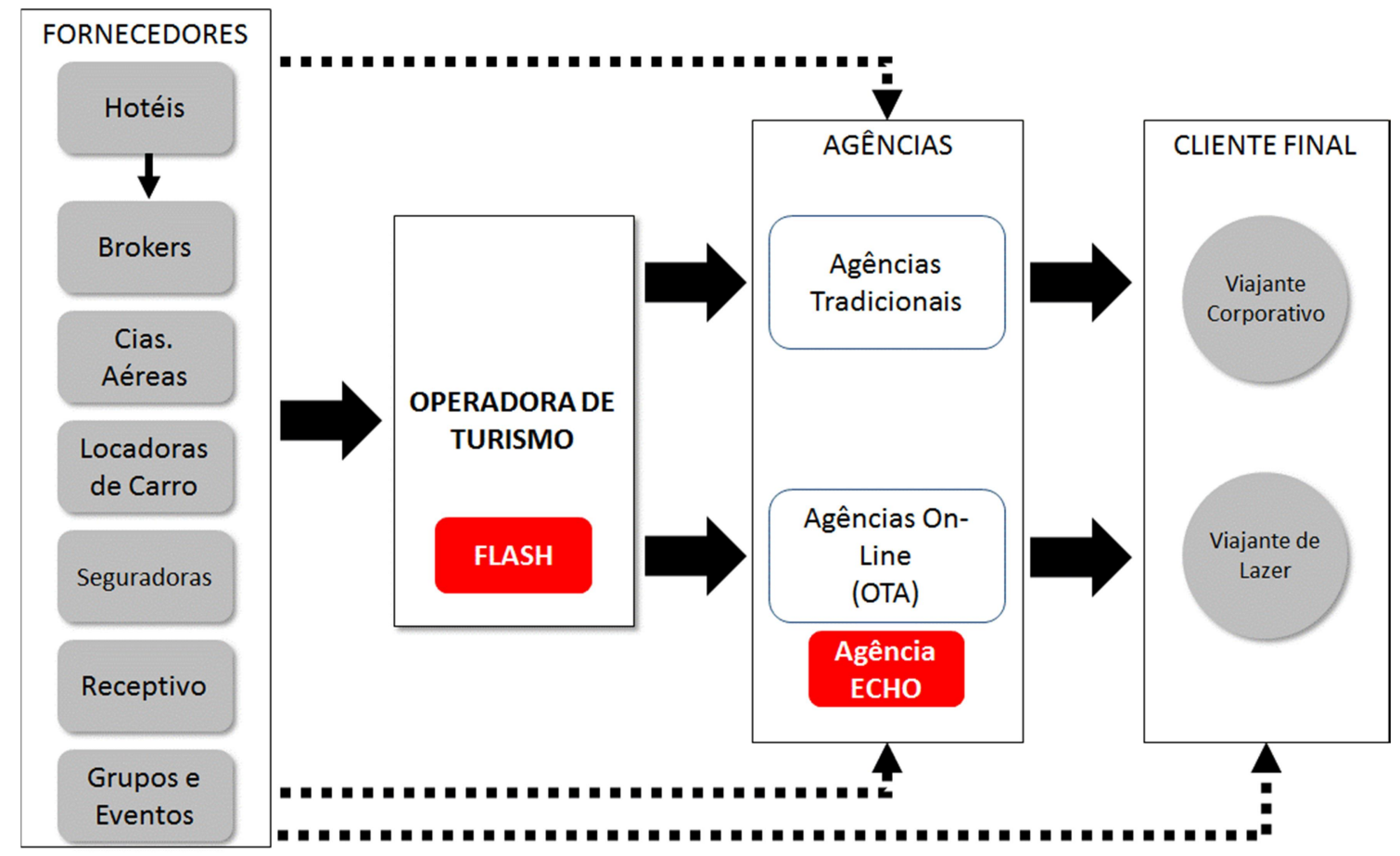

Ilustração 5 - Posição das spin-offs estudadas na cadeia do turismo

\subsubsection{Projeto Flash}

O autor desenvolveu o modelo que será apresentado, com base em sua experiência profissional e acadêmica em gestão estratégica e de projetos corporativos.

Apesar de hoje o mesmo estar estruturado em formato de tópicos, quando utilizado na implantação da Flash foi realizado de forma intuitiva. Apesar de ter gerenciado diversos projetos, o autor não possuía experiência prévia com criação de novos negócios em formato de spin-off.

Outro detalhe importante, tais itens estão classificados como de planejamento pois foram considerados ANTES do início do projeto de implantação. Algumas questões que de planejamento que foram entregues ao final do projeto (exemplo: organograma da empresa e estrutura de pessoas) foram elaborados após o início do projeto. Por não terem sido planejados previamente não podem ser incluídos como itens de planejamento.

O projeto de implantação da nova empresa foi executado entre março e setembro de 2014, com inauguração efetiva da unidade no dia 24/09. Ao longo desse período, o autor atuou como o principal líder do projeto de implantação, participando desde o refinamento dos 
conceitos e estratégia do negócio à gestão dos primeiros passos da nova empresa até seu amadurecimento.

Em termos de etapas, foram as seguintes:

Tabela 2 - Etapas de Planejamento Projeto Flash

\begin{tabular}{|l|l|}
\hline ITEM & ETAPAS DE PLANEJAMENTO - PROJETO FLASH \\
\hline 3.2 .2 .1 & CONCEPÇÃO CONCEITUAL DO NEGÓCIO \\
\hline 3.2 .2 .2 & DEFINIÇÃO DE MODELO DE NEGÓCIO E ESTRATÉGIA DA EMPRESA \\
\hline 3.2 .2 .3 & VALIDAÇÃO DO MODELO DE NEGÓCIO \\
\hline 3.2 .2 .4 & CONSTRUÇÃO DO ORÇAMENTO E PLANEJAMENTO FINANCEIRO \\
\hline 3.2 .2 .5 & PLANEJAMENTO DO PROJETO DE IMPLANTAÇÃO \\
\hline 3.2 .2 .6 & EXECUÇÃO DO PROJETO DE IMPLANTAÇÃO \\
\hline 3.2 .2 .7 & ACOMPANHAMENTO DOS RESULTADOS E TRANSIÇÃO \\
\hline
\end{tabular}

Abaixo, a explicação de cada uma delas e um breve contexto:

\subsubsection{Concepção Conceitual do Negócio}

Essa etapa consistiu na apresentação da ideia inicial para o novo negócio. No caso da Flash, a ideia foi apresentada pelo Presidente da Empresa Alpha que explicou a origem da oportunidade e os principais elementos que deveriam compor as bases para o modelo de negócio da nova empresa.

Essa apresentação foi realizada para 4 colaboradores da empresa mãe: o Vice-Presidente Administrativo Financeiro, o Vice-Presidente comercial (relação com fornecedores), a VicePresidente de Vendas e o Gerente de Estratégia e Inovação (autor do presente trabalho).

Em resumo, a principal motivação para criação de uma nova empresa foi segmentar o alcance a determinados clientes que não eram atendidos de forma satisfatória pela empresa mãe.

A deficiência no atendimento a esses clientes ocorria principalmente, porque os serviços oferecidos não agregavam valor às suas necessidades. Tais clientes eram agências de viagens menores, cuja principal necessidade era ter acesso a produtos e serviços turísticos com preços competitivos, de modo que a oferta do pacote completo de serviços da empresa mãe não lhes era atraente ou apresentava menos relevância em sua decisão. 
Em contrapartida à visão do cliente, para a empresa mãe atender tais consumidores não era vantajoso, uma vez que não possuíam frequência regular de compra e apresentavam baixo volume de negócios. Entretanto, estes eram atendidos pela mesma estrutura que prestava atendimento à grandes clientes; de modo que na ocasião da implantação da empresa havia conflito nas estruturas operacionais para atendimento a esses dois tipos de consumidores, gerando reclamações por parte daqueles de maior porte.

Com base nesse cenário a ideia apresentada pelo Presidente da empresa visou criar uma nova empresa que atuaria como "concorrente" da empresa mãe e atenderia os seguintes objetivos:

(i) Ocupar mais espaço de mercado

(ii) Dividir marcas

(iii) Adequar clientes

(iv) Distinguir posicionamento

(v) Agredir os concorrentes nativos

Ainda nessa fase, no caso da Flash, foram apresentadas (pelo próprio Presidente) algumas premissas e restrições para o projeto, que deveriam nortear a solução do problema acima, são elas:

(i) O projeto deveria correr sob o mais absoluto sigilo

(ii) Deveria ser criada uma nova empresa

(iii) Essa empresa deveria ser implantada em alguma cidade da grande São Paulo onde existam ganhos fiscais.

(iv) Atendimento primordialmente on-line (chat + e-mail)

(v) Atendimento de exceção via telefone (emergência)

(vi) Aproveitamento dos acordos comerciais já estabelecidos com a empresa mãe

(vii) Ampla capacidade de flutuação no preço

\subsubsection{Definição de modelo de negócio e estratégia da empresa}

Após a apresentação da ideia, ficou a cargo do gerente de estratégia e inovação, em conjunto com os executivos, estabelecer o modelo de negócio, bem como as principais características da nova empresa. 
Para tal, foram utilizadas a ferramentas: (i) Matriz de Proposta de Valor - retirada da Estratégia do Oceano Azul de Kim e Mauborgne (2005) - e (ii) BMG - Business Model Generation Canvas de Osterwalder e Pigneur (2010).

A primeira ferramenta, foi utilizada pois permite análise e reflexão de uma Proposta de Valor já existente e evoca a elaboração de alterações na mesma para se atingir um novo tipo de mercado, cliente ou criação de algum novo atributo para o negócio. Como a premissa do negócio era justamente a criação de uma nova operadora de turismo - à luz da já existente empresa ALPHA - porém para atender um novo perfil de cliente, foi utilizada essa ferramenta.

Com isso, a matriz de Proposta de Valor ficou conforme demonstra a ilustração 6 abaixo.

\section{Matriz de Proposta de Valor}

\begin{tabular}{|c|c|}
\hline \begin{tabular}{l}
\multicolumn{1}{c}{ Eliminar } \\
$\begin{array}{l}\text { - } \\
\text { - }\end{array}$ Faturamento manual \\
- $\quad$ Equipe de vendas \\
- Melhorias de sistema (processo para vender \\
commodity)
\end{tabular} & \begin{tabular}{l}
\multicolumn{1}{c}{ Elevar } \\
- Atendimento on-line \\
- Automação dos processos \\
-
\end{tabular} \\
\hline \begin{tabular}{l}
\multicolumn{1}{c}{ Reduzir } \\
- $\quad$ Portfólio de produtos (só hotel) \\
- Atendimento off-line (manter apenas conversão \\
de pedidos eletrônicos) \\
- Interação com equipe de atendimento \\
Quantidade de Brokers. Trabalhar somente com \\
os produtos que permitem melhor redução da \\
margem.
\end{tabular} & $\begin{array}{l}\text { Criar } \\
\text { - Taxa para processos offline (emissão, alteração e } \\
\text { cancelamento) } \\
\text { - Taxa por transação } \\
\text { - Modelo de custo para "pagar" as estruturas } \\
\text { compartilhadas com a empresa mãe }\end{array}$ \\
\hline
\end{tabular}

Ilustração 6 - Matriz de Proposta de Valor Flash FONTE: KIM; MAUBORGNE; 2005 (Adaptado).

Com base nessa matriz, somado ao entendimento da ideia inicial do negócio, o gerente escreveu uma versão do $B M G$ e em seguida o validou (em uma reunião coletiva) com os Vice-Presidentes e o Presidente. 
A estratégia previu diretrizes (premissas e restrições) para a criação da Flash. Dentre essas premissas uma era específica sobre a relação de compartilhamento de recursos entre a Empresa ALPHA (empresa mãe) e a Flash (spin-off).

Essa definição determinou quais processos seriam compartilhados entre as duas empresas e quais seriam independentes. Abaixo segue brevemente a relação de tais processos:

Processos Compartilhados:

- Contratação (Fornecedores) - Todo relacionamento com fornecedores deveria ser efetuado pela empresa mãe, de tal modo que a Flash "consumirá" o conteúdo dos acordos que a empresa mãe já tem e venha a firmar com futuros fornecedores. Fornecedores que desejam trabalhar com a Flash

- Base de Clientes - Alguns clientes que já fazem parte da carteira da empresa mãe seriam automaticamente migrados para a nova empresa. Assim, esses clientes não teriam que efetuar novo cadastro ou pleitear limite de crédito à Flash. Entretanto a Flash tem liberdade para prospecção de novos clientes que podem ser exclusivos de sua operação se assim os mesmos desejarem. Tem também autonomia para atuar de maneira diferenciada em clientes compartilhados.

- Equipes Administrativas (marketing, RH, jurídico, etc.) - os processos de suporte serão executados por equipes da empresa mãe. O baixo volume de tais processos na spin-off não justifica ter estruturas estabelecidas para essas atividades.

\section{Processos Independentes:}

- Operações Financeiras - Todas as rotinas financeiras (faturamento, contas a pagar, a receber, conciliação, emissão de Nota Fiscal, etc.) devem ser executadas na spin-off. Essa além de uma questão estratégica, mostra-se como uma imposição legal para justificar a instalação de uma empresa em outro município.

- Sistema de Vendas - A infraestrutura tecnológica utilizada pela Spin-off foi desenvolvida por uma empresa externa especializada em soluções para o mercado de turismo. Essa decisão contrasta radicalmente da posição da empresa mãe que tradicionalmente opta por desenvolver e manter as plataformas de tecnologia sob sua estrutura. 
- Atendimento - $\mathrm{O}$ atendimento aos clientes da spin-off ocorreria exclusivamente via Chat. Limitando com isso a incidência de ligações telefônicas. Como a alteração na forma de atendimento é um dos itens da proposta de valor da spin-off, essa atividade ficou exclusivamente com a nova empresa.

- Inteligência de Negócios - Foi previsto que essa equipe também deveria ser exclusiva, principalmente para atender a necessidade de gestão flutuante dos preços.

Com base nessas definições chegou-se ao seguinte modelo de negócios, disposto na ilustração 7 abaixo:

\section{Modelo de Negócios}

\begin{tabular}{|c|c|c|c|c|c|}
\hline \multirow[t]{2}{*}{$\begin{array}{l}\text { Parcerias Chave } \\
\text { - Empresa Alpha }\end{array}$} & $\begin{array}{l}\text { Atividades Chave } \\
\text { - Negociação } \\
\text { - Pré-compra } \\
\text { - Comunicação } \\
\text { - Operação enxuta }\end{array}$ & \multirow{2}{*}{\multicolumn{2}{|c|}{\begin{tabular}{l}
\multicolumn{1}{l}{ Proposta de Valor } \\
Ser a distribuidora de \\
hotéis com melhor \\
condição de preços do \\
mercado \\
-Melhores tarifas \\
- Operação on-line \\
- Serviço simplificado \\
- Preço baixo e crédito
\end{tabular}}} & $\begin{array}{l}\text { Relacionamento com Cliente } \\
\text { - Sistema eficiente } \\
\text { - Processo com mínimo } \\
\text { de falha } \\
\text { - Atendimento seletivo e } \\
\text { que resolva } \\
\text { - Trabalhar somente } \\
\text { Tarifa Net }\end{array}$ & \multirow[t]{2}{*}{$\begin{array}{l}\text { Segmento de Clientes } \\
\text { - Cliente que busca } \\
\text { hotel com tarifa baixa } \\
\text { e sem outra } \\
\text { necessidade } \\
\text { adicional. } \\
\text { - B2B }\end{array}$} \\
\hline & $\begin{array}{l}\text { Recursos Chave } \\
\text { - Sistema } \\
\text { - Inteligência de Negócios }\end{array}$ & & & $\begin{array}{l}\quad \text { Canais Chave } \\
\text { - Portal } \\
\text { - Atendimento (somente } \\
\text { para os casos de falhas) } \\
\text { - Integração Direta } \\
\text { (conexão sistêmica) } \\
\text { - Mobile }\end{array}$ & \\
\hline \multicolumn{3}{|c|}{$\begin{array}{l}\text { Estrutura de Custos } \\
\text { Operação enxuta e mínima } \\
\text { Baixo custo por reserva } \\
\text { No caso de pagamento via cartão a comissão paga será a informada } \\
\text { pelo cliente. }\end{array}$} & \multicolumn{3}{|c|}{$\begin{array}{l}\text { Fontes de Receita } \\
\text { Volume de negócios } \\
\text { Fee de solicitaçốes extraordinárias } \\
\text { Receita de Mídia, Negociaçôes pontuais com fornecedores e clientes. }\end{array}$} \\
\hline
\end{tabular}

\subsubsection{Validação do Modelo de Negócio}

Essa etapa consistiu em apresentar para o presidente e demais executivos da empresa o modelo de negócio e a sua cadeia de valor. 
O principal objetivo dessa etapa foi expor a dimensão do projeto e o esforço necessário para implantação da nova empresa. Na visão do autor, se faz necessária, pois no momento da concepção do negócio eventualmente o Presidente não contemplava a complexidade e a quantidade de tarefas envolvidas. Além disso, com o modelo de negócio devidamente documentado e estruturado, ficam evidentes os recursos e investimentos necessários.

Notou-se que houve um "choque de realidade" quando ficou claro que a criação do novo negócio demandaria uma grande carga de trabalho para diversas equipes da companhia. Entretanto, esse ocorrido mobilizou o Presidente para estar presente durante a execução do projeto, para garantir a devida prioridade das atividades de implantação frente às demais da empresa.

\subsubsection{Construção do Orçamento e Planejamento Financeiro}

Após validação do modelo de negócio. O projeto seguiu para a fase de elaboração das projeções financeiras.

A primeira etapa dessa fase foi o levantamento da necessidade de investimentos e estimativas de custos. Para isso foi utilizado como base a estrutura de custos da empresa mãe.

Por política da companhia os negócios são precificados com base na rentabilidade mínima esperada pelos sócios. Portanto, mediante a estimativa de gastos foi calculado o Ponto de Equilíbrio para encontrar o faturamento mínimo e então projetar as metas de desempenho da empresa. As projeções foram realizadas para 36 meses, outra regra utilizada pela empresa ALPHA.

\subsubsection{Planejamento do Projeto de Implantação}

Mediante criação e aprovação do orçamento, foi elaborado o plano de implantação do projeto. Foi seguida metodologia da empresa mãe, que fora desenvolvida pelo autor quando ocupou a posição de Gerente de Projetos na empresa ALPHA. 
Nessa fase, foram listadas todas as atividades, atribuído os responsáveis e prazos para cada uma delas.

O conhecimento do negócio foi fundamental na criação do plano de implantação, pois muitos processos da spin-off eram semelhantes aos da empresa mãe, dessa forma, as atividades para implantação dos mesmos foram desenhadas com mais precisão. Outro aspecto onde a experiência com o negócio da empresa mãe fez diferença, foi em acionar / designar responsabilidade para as pessoas chave dentro da organização. O bom relacionamento com as diferentes equipes da empresa mãe permitiu um trâmite rápido e também preciso na forma em que elas se relacionaram com o projeto.

O projeto de implantação foi estruturado conforme ilustração 8 a seguir: 


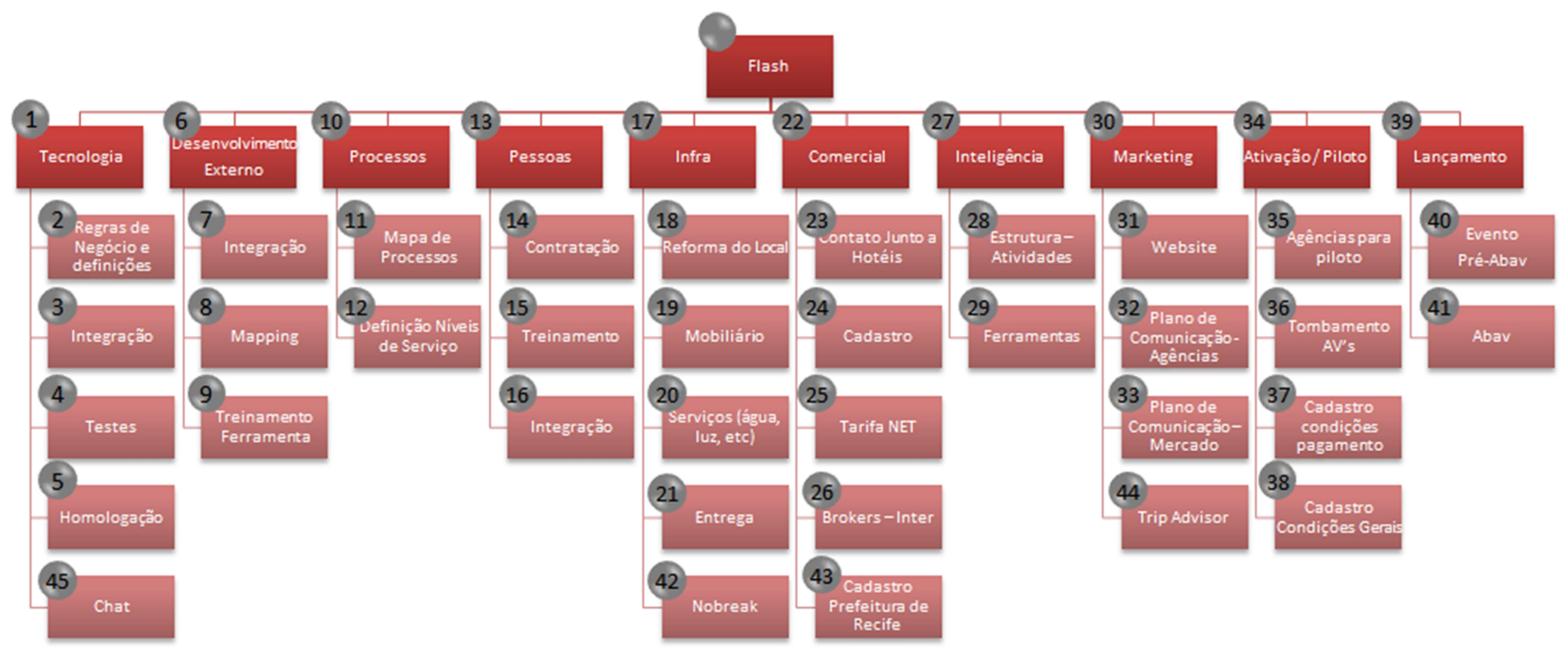

Ilustração 8 - Estrutura do Projeto Flash 


\subsubsection{Execução do Projeto de Implantação}

O plano do projeto foi dividido com os principais executores. Quinzenalmente, eram realizadas reuniões dessas pessoas com o líder do projeto, onde as atividades em curso eram debatidas, alinhadas e reportadas. Semanalmente, o líder do projeto emitia um relatório de acompanhamento, indicando o status de cada atividade.

Quinzenalmente também era realizada uma reunião com os principais executivos da empresa mãe para alinhamento e tomada de decisão. Eventualmente, situações urgentes que dependiam da decisão da alta liderança eram encaminhadas de forma imediata; em ambas as reuniões o autor era responsável por promover e conduzir os encontros.

A gestão próxima do projeto foi um fator decisivo para amenizar as tensões e conflitos provocados na empresa mãe durante a implantação; pois o fato de ser o projeto sigiloso, causava questionamentos na equipe, exigindo atuação rápida para esclarecimentos adequados e evitar ruídos desnecessários.

A execução do projeto, durou 7 meses e compreendeu desde o planejamento até o lançamento oficial do negócio para o mercado.

\subsubsection{Acompanhamento de Resultados e Transição}

Após lançamento do negócio foi tarefa do autor, acompanhar o negócio em seus primeiros meses; sendo responsável pelo resultado de negócio e também gestão operacional.

Essa etapa foi fundamental para resolver problemas e ocorrências não previstas durante as etapas de planejamento e execução do projeto; principalmente àquelas relacionadas à dinâmica de um negócio novo.

Pois mesmo sendo a spin-off uma operadora de turismo, o fato de abordar um novo mercado de forma diferente da empresa mãe, apresentou situações novas, exigindo criatividade e flexibilidade para endereçar tais questões. 
Após seis meses de operação, estando a spin-off operacionalmente estável, foi realizado a transição do negócio para um líder definitivo. O motivo dessa transição foi alocar no negócio uma liderança mais alinhada com o perfil de resultados e vendas, etc. Esse movimento, futuramente, se mostrou muito importante, pois envolveu, em fases diferentes, dois profissionais de perfis distintos e permitiu que o projeto fosse planejado e implantado, amadurecido e então expandido, aproveitando o melhor das expertises e garantido robustez nas entregas do novo negócio.

\subsubsection{Projeto Agência Echo}

O autor foi acionado para condução do projeto da Agência Echo em novembro de 2015. Na ocasião o projeto da spin-off já havia sido iniciado, porém todo o foco de trabalho das equipes até então alocadas no projeto, tinha sido na concepção da ferramenta de tecnológica que suportaria o negócio. De tal modo as demais atividades e tarefas necessárias para se estabelecer a nova empresa precisavam ser definidas, organizadas e executadas.

Considerando a experiência vivida com a implantação do projeto da Flash o autor aprimorou o planejamento do negócio antes do início do projeto, de modo que o mesmo fícou estruturado da seguinte forma:

Tabela 3 - Estrutura do Plano de Implantação Echo

\begin{tabular}{|l|l|}
\hline ITEM & ETAPAS DE PLANEJAMENTO - PROJETO ECHO \\
\hline 3.2 .3 .1 & CONCEITO DO NEGOCIO \\
\hline 3.2 .3 .2 & ANÁLISE DE MERCADO \\
\hline 3.2 .3 .3 & MODELO DE NEGÓCIO \\
\hline 3.2 .3 .4 & GOVERNANÇA CORPORATIVA \\
\hline 3.2 .3 .5 & ESTRUTURA DA EMPRESA \\
\hline 3.2 .3 .6 & PLANEJAMENTO FINANCEIRO \\
\hline 3.2 .3 .7 & PROJETO DE IMPLANTAÇÃO \\
\hline
\end{tabular}

\subsubsection{Conceito do Negócio}

A Agência Echo (Echo), foi concebida para atender Pequenas e Médias empresas e profissionais liberais em suas necessidades de viagens. Seu planejamento foi realizado entre novembro de 2015 e janeiro de 2016; o início das atividades estão previstos para agosto de 2016. 
A ideia foi apresentada por uma Agência de Viagens (que será chamada de PARCEIRA) é cliente da Empresa ALPHA. A PARCEIRA é uma grande empresa no segmento das viagens corporativas e tem como seus clientes grandes empresas nacionais e multinacionais.

A Empresa ALPHA foi procurada, justamente por deter grande poder de barganha junto aos hotéis e empresas de locação de carro. A PARCEIRA por sua vez, tem poder de barganha junto a companhias aéreas; de tal modo que a junção de ambas expertises permite criar uma cesta de produtos que agrega valor às necessidades do público alvo.

Além da oportunidade em termos de produto, foi premissa que a Echo seja uma empresa $100 \%$ digital, com todo o processo de divulgação, compra, atendimento e pós-venda sendo realizado via portal na internet; a intenção com isso é permitir conveniência ao cliente, que, por ser um empresário de pequeno porte, precisa ter seu tempo otimizado ao máximo. Em complemento à essa premissa, foi determinado que a pessoa responsável por assumir a operação da Agência Echo, deveria ser um profissional com vasta experiência em mercado digital, ou seja, alguém com domínio em ferramentas e plataformas tecnológicas de relacionamento, vendas e publicidade. Conhecimento na administração de orçamentos publicitários para divulgação em plataformas de internet, adwords ${ }^{5}$, analytics ${ }^{6}$, big data $^{7} \mathrm{e}$ redes sociais.

Uma restrição colocada ao negócio é que a sua relação em termos de sinergia e compartilhamento de recursos deve ser com a PARCEIRA. Em termos práticos isso indica que a empresa mãe para essa spin-off é a PARCEIRA. Tal medida, é necessária pois a expertise de agência de viagens é algo presente na PARCEIRA e não na Empresa ALPHA.

\subsubsection{Análise de Mercado}

Quando o autor assumiu a gestão do projeto os aspectos de mercado já haviam sido considerados na construção do projeto. Todo estudo foi realizado com base na experiência do

\footnotetext{
${ }^{5}$ Adwords - Ferramenta da empresa Google de publicidade online baseada em cliques e posicionamento em plataformas de busca. (Google, 2016a).

${ }^{6}$ Analytics - Ferramenta da empresa Google para avaliação dos investimentos em publicidade online bem como acompanhamento do desempenho de navegação de sites da internet. (Google, 2016b).

${ }^{7}$ Big Data - Big Data é o termo que descreve o imenso volume de dados - estruturados e não estruturados - que impactam os negócios no dia a dia. (BIG DATA, 2016).
} 
Diretor Presidente da PARCEIRA. Foi considerado justamente o mercado de agências de viagens corporativas.

Conforme mencionado anteriormente a PARCEIRA é uma das maiores empresas no seu segmento de turismo corporativo. A empresa tem como principais clientes, grandes companhias nacionais e estrangeiras, dispondo de uma estrutura grande de pessoas e processos para atendê-los

Para a empresa Alpha, atender empresas pequenas e médias não fazia parte de sua estratégia, pois o custo envolvido na prestação de seus serviços tornaria a oferta cara para esse perfil de cliente.

Entretanto, foi percebido que não havia no mercado, nenhum tipo de empresa ou solução para atender as necessidades de viagens desse público, que quando precisa viajar a negócios, efetua a compra, priorizando geralmente o preço e por diferentes fornecedores; portanto é comum que adquiram cada serviço (diária de hotel, locação e carro ou passagem aérea) em fornecedores diferentes e tendo que gerenciar todo o processo de unificação da compra.

Com isso, a forma encontrada para atender esse nicho de mercado foi criar um novo negócio, apartado da empresa mãe e com uma oferta adequada à necessidade desses clientes. Mais que simplesmente oferecer os produtos, a intenção do Diretor Presidente foi criar atrativos adicionais para estabelecer fidelidade com os clientes.

Tais atrativos, seriam serviços e produtos adicionais que agreguem valor a uma viagem corporativa, como por exemplo: descontos em corridas de Taxi, proteção de bagagem, descontos em refeição, etc.

\subsubsection{Modelo de Negócios}

Após alinhamento com os sócios o autor criou o modelo de negócios conforme ilustração 9 a seguir, novamente baseado no BMG Canvas. 


\section{Modelo de Negócios}

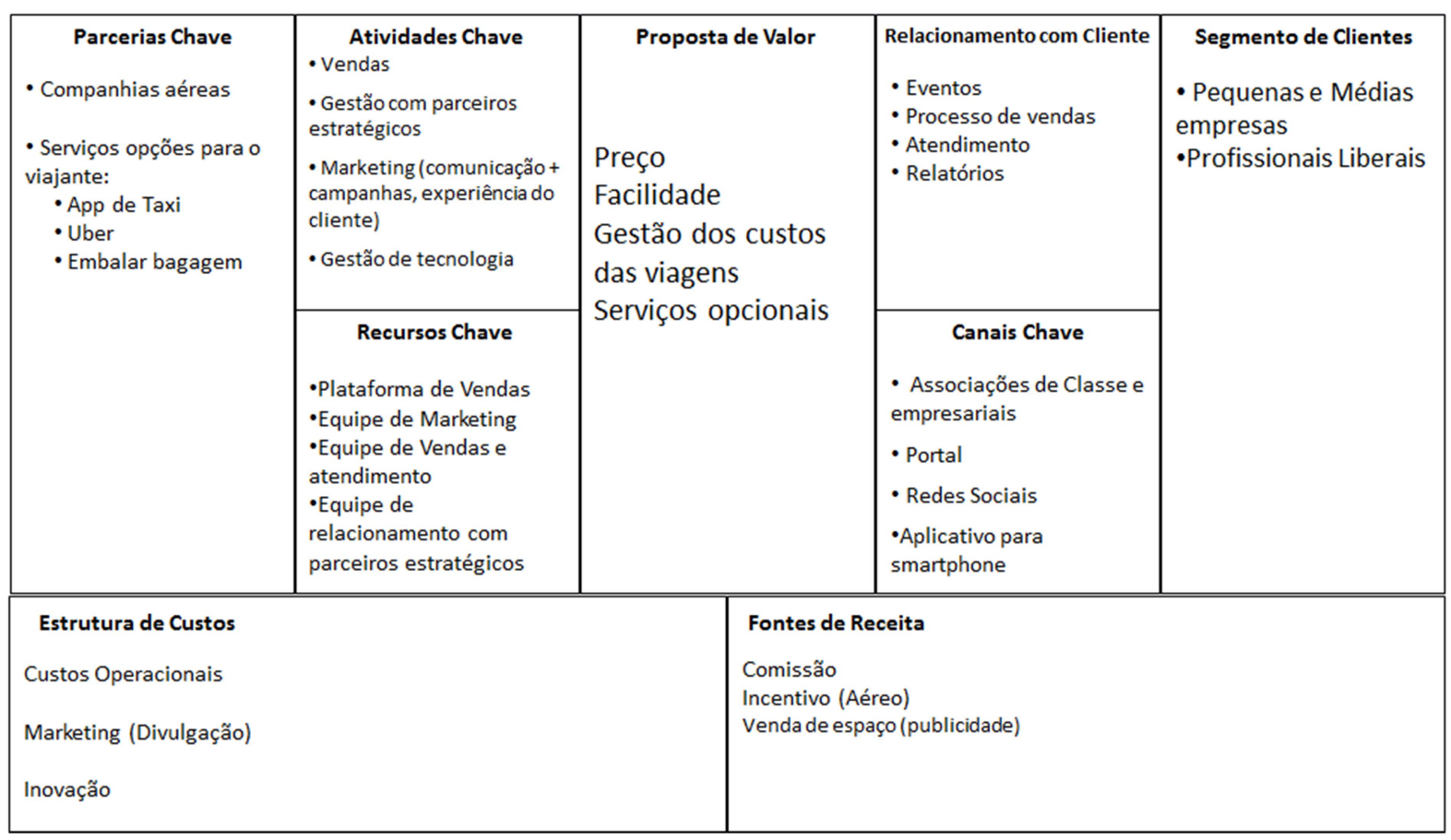

Ilustração 9 - BMG Canvas Agência Echo

\subsubsection{Governança Corporativa}

Aqui a principal função foi estruturar a relação entre empresas e principalmente entre a empresa mãe e a spin-off. A experiência do autor enquanto líder temporário da Flash mostrou que numa estrutura de compartilhamento de recursos, é de suma importância que tais itens sejam muito claros. Considerando que a Echo é também uma sociedade entre duas empresas o autor considerou necessário clareza nas responsabilidades da sociedade.

Em termos de papéis e responsabilidades, foram definidos 3 níveis decisórios na empresa, a saber:

Conselho: formado pelos Presidentes da Operadora ALPHA e da PARCEIRA. Esse nível ficou responsável por definições estratégicas da empresa bem como qualquer necessidade de investimento e/ou alterações na estrutura societária da empresa. 
Board: formado por diretores e/ou vice-presidentes das duas empresas. Tem como responsabilidade o planejamento das demandas estratégicas, bem como ser o ponto focal para relacionamento e acompanhamento com o Gestor da spin-off.

Gestor: será o responsável pela condução do negócio no dia-a-dia, implantação das ações, relacionamento com clientes e parceiros. De modo que deve ter autonomia para tomada de decisão operacional.

Em resumo, a estrutura da governança corporativa da Echo pode ser explicada pela ilustração 10 a seguir:

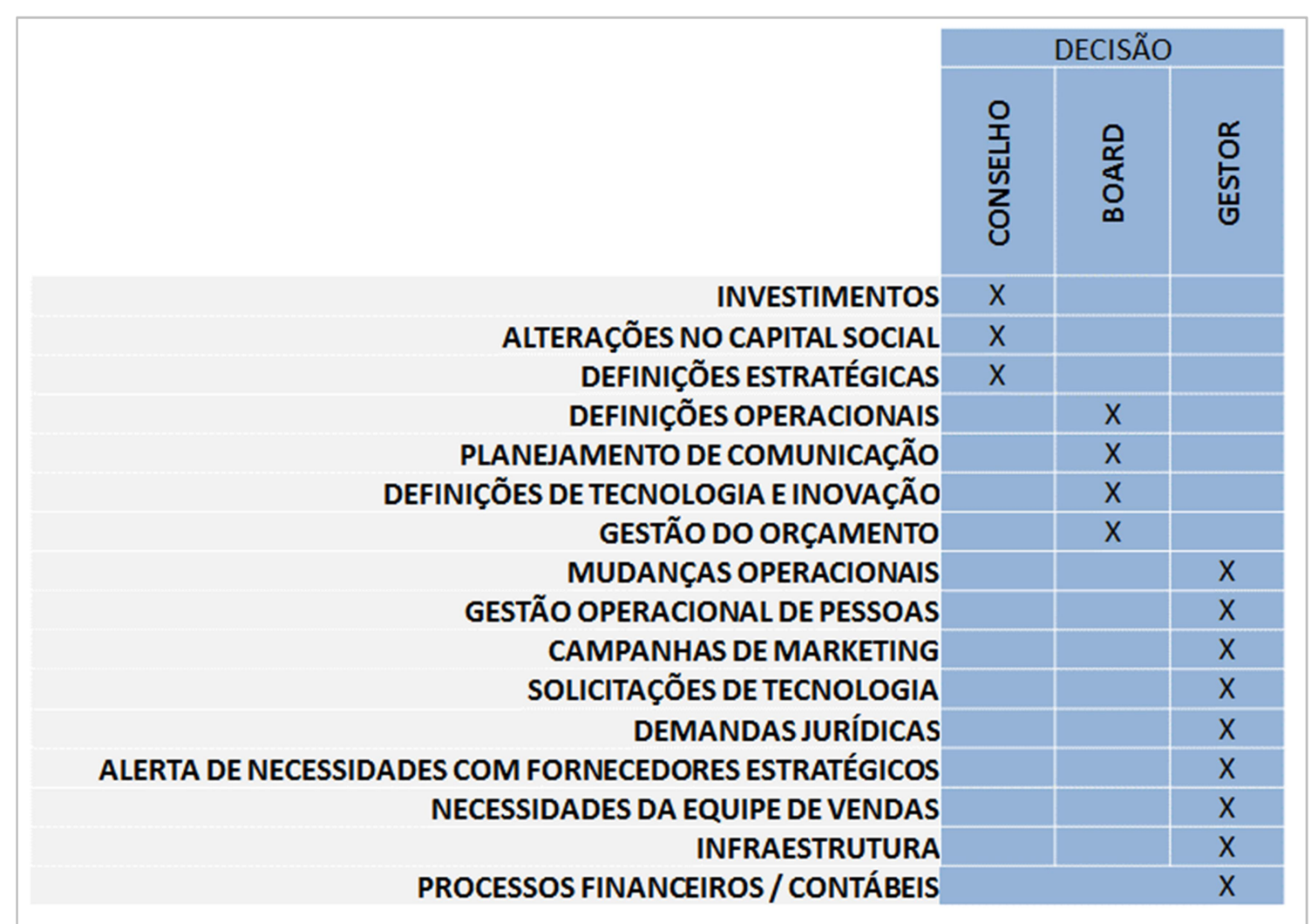

Ilustração 10 - Governança Corporativa - Agência Echo

Sobre a relação de compartilhamento entre empresa mãe e spin-off, foi mencionado que a PARCEIRA terá os "laços" com a spin-off. Entretanto, em alguns processos, haverá uma relação com a empresa ALPHA, eventualmente por tais processos serem mais maduros nessa empresa.

Com base nessa premissa, para organizar a relação de compartilhamento, o autor listou os principais processos e então, em conjunto com os Presidentes das empresas, definiu onde o 
processo seria executado. Levou-se em consideração que os processos e atividades críticos para o negócio, fossem executados dentro da Echo, justamente para garantir agilidade na tomada de decisão e total aderência ao modelo de negócio e suas necessidades. A Tabela abaixo resume a relação de compartilhamento.

Tabela 4 - Compartilhamento de Processos: Agência Echo

\begin{tabular}{|c|c|c|c|c|}
\hline \multicolumn{5}{|c|}{ COMPARTILHAMENTO DE PROCESSOS - AGÊNCIA ECHO } \\
\hline ÁREA & \begin{tabular}{|c|} 
PROCESSO \\
\end{tabular} & ЕСHO & PARCEIRA & ALPHA \\
\hline \multirow{4}{*}{ RECURSOS HUMANOS } & RECRUTAMENTO E SELEÇÃO & & $\mathrm{X}$ & \\
\hline & DEPTO PESSOAL & & $\mathrm{X}$ & \\
\hline & GESTÃO CARREIRA & & $\mathrm{X}$ & \\
\hline & TREINAMENTO & & & $\mathrm{X}$ \\
\hline \multirow{3}{*}{ OPERAÇÕES FINANCEIRAS } & FATURAMENTO & $\mathrm{X}$ & & \\
\hline & CONTAS A PAGAR & $\mathrm{X}$ & & \\
\hline & CONTAS A RECEBER & $\mathrm{X}$ & & \\
\hline \multirow{2}{*}{ CONTROLADORIA } & FLUXO DE CAIXA & $\mathrm{X}$ & & \\
\hline & APURAÇÃO DE RESULTADOS & & & $\mathrm{X}$ \\
\hline \multirow{5}{*}{ MARKETING } & $\begin{array}{l}\text { CAMPANHAS DE } \\
\text { DIVULGAÇÃO }\end{array}$ & $X$ & & \\
\hline & PRODUÇÃO DE MATERIAIS & $\mathrm{X}$ & & \\
\hline & CRIAÇÃO & & $\mathrm{X}$ & \\
\hline & GESTÃO DE EVENTOS & & $\mathrm{X}$ & \\
\hline & MARKETING DIGITAL & $X$ & & \\
\hline \multirow{2}{*}{ INTELIGÊNCIA } & INTELIÊNCIA DE VENDAS & $\mathrm{X}$ & & \\
\hline & INTELIGÊNCIA COMPETITIVA & $X$ & & \\
\hline QUALIDADE E PROCESSOS & $\begin{array}{l}\text { PAINEIS DE CONTROLE } \\
\text { OPERACIONAIS }\end{array}$ & $\mathrm{X}$ & & \\
\hline \multirow{4}{*}{ ADMINISTRATIVO } & COMPRAS & & $\mathrm{X}$ & \\
\hline & REEMBOLSO & & $\mathrm{X}$ & \\
\hline & MANUTENÇÃO & & $\mathrm{X}$ & \\
\hline & REFORMAS E CONSTRUÇÕES & & $\mathrm{X}$ & \\
\hline \multirow{4}{*}{ JURÍDICO } & $\begin{array}{l}\text { ELABORAÇÃO DE } \\
\text { CONTRATOS }\end{array}$ & & $\mathrm{X}$ & \\
\hline & ANÁLISE DE CONTRATOS & & $\mathrm{X}$ & \\
\hline & CONSULTORIA & & $\mathrm{X}$ & \\
\hline & LITIGIOSO & & $\mathrm{X}$ & \\
\hline \multirow{5}{*}{ GESTÃO DE TI } & INFRAESTRUTURA & & $\mathrm{X}$ & \\
\hline & HELP DESK & & $\mathrm{X}$ & \\
\hline & $\begin{array}{l}\text { SEGURANÇA DA } \\
\text { INFORMAÇÃO }\end{array}$ & & $\mathrm{X}$ & \\
\hline & MANUTENÇÃO DE SISTEMAS & & $\mathrm{X}$ & \\
\hline & QUALITY ASSURANCE & & $\mathrm{X}$ & \\
\hline \multirow{3}{*}{ DESENVOVIMENTO DE TI } & DESIGN & & & $\mathrm{X}$ \\
\hline & GESTÃO DE PROJETOS & & & $\mathrm{X}$ \\
\hline & DESENVOLVIMENTO & & $\mathrm{X}$ & \\
\hline PLANTÃO & PLANTÃO 24H & $\mathrm{X}$ & & \\
\hline
\end{tabular}




\subsubsection{Estrutura da Empresa}

Nessa seção foram definidos: o local, os processos e a equipe para início da operação.

Local: ficou definido que a empresa seria instalada no mesmo endereço da PARCEIRA, justamente para facilitar o compartilhamento de recursos e também pela disponibilidade de espaço no edifício em questão.

Cadeia de Processos: os principais processos da empresa foram definidos para início da operação em regime de piloto. Foi decidido dessa forma, pois é previsto que com o início da operação os processos sofram alterações mediante a necessidade dos clientes.

Equipe: foram definidas a quantidade de pessoas e o perfil desses colaboradores a serem contratados. Um aspecto importante foi a definição do perfil do Gerente Geral a ser contratado para conduzir a operação após a entrega do Projeto. Foi uma exigência que essa pessoa tivesse amplo conhecimento em Gestão de Negócios e, principalmente, marketing digital.

\subsubsection{Planejamento Financeiro}

O planejamento financeiro foi executado da mesma forma que no projeto Flash. Com base em todos os passos anteriores do Plano de Negócios, foram definidos os custos e despesas estimados do negócio e, com isso, qual a receita esperada. Uma particularidade do projeto Echo, foi a definição das regras para aporte de capital, investimento, retirados dos sócios e realização dos lucros ou prejuízos entre a empresa ALPHA e a PARCEIRA. A decisão foi que em todas as questões acima mencionadas cada empresa teria participação de cinquenta por cento.

\subsubsection{Projeto de Implantação}

O projeto de implantação também seguiu o mesmo padrão do caso Flash. Entretanto a divisão das atividades para implantação, foram mais aderentes às necessidades de implantação de um novo negócio, pois preocupações como a o Planejamento do Negócio, Abertura da Empresa e mesmo a Gestão do Projeto foram estruturadas de maneira mais explícita. 
A estrutura do projeto encontra-se representada na Ilustração a seguir: 


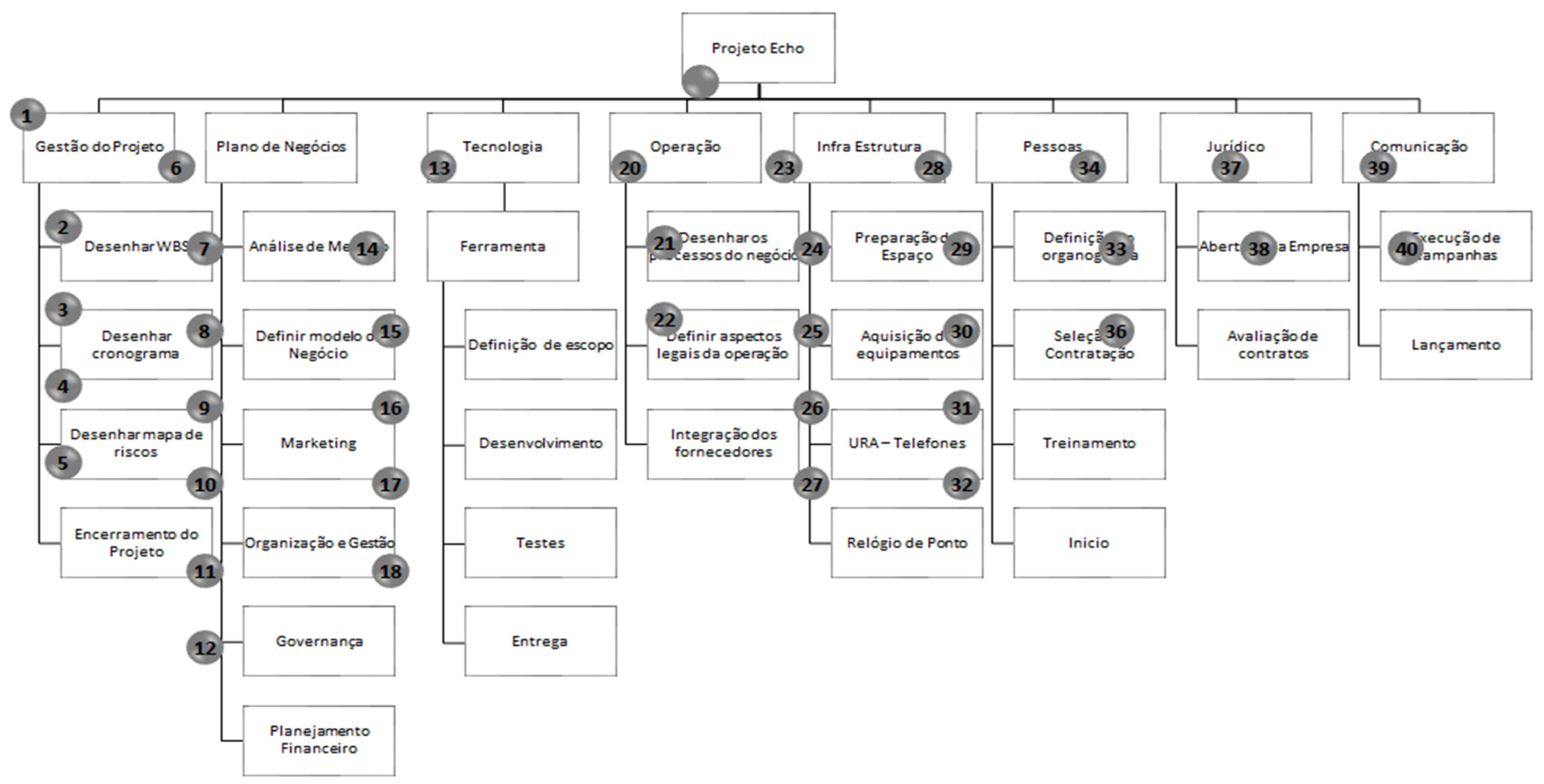

Ilustração 11 - Estrutura do projeto Echo 


\section{REFERENCIAL TEÓRICO}

\subsection{Spin-Offs corporativas}

Essa sessão busca aprofundar o entendimento sobre spin-offs nas seguintes frentes: estabelecer uma definição de spin-off corporativa mediante breve estudo de autores que já abordaram o tema. Em seguida, diferenciar spin-off corporativa da spin-off acadêmica, relacionando as principais diferenças entre esses dois tipos de empresa. Na sequência, contextualizar a importância das spin-offs como estratégia de negócios e por fim abordar os aspectos de relação entre a empresa mãe e a spin-off.

\subsubsection{O que é spin-off corporativa?}

A primeira parte da pesquisa visa trazer os principais elementos sobre o tema das spin-offs corporativas.

Primeiramente, é importante ressaltar que "spin-off" é um substantivo de língua inglesa que não possui gênero em sua forma nativa e também não possui uma tradução específica para o português. Portanto pode ser encontrado (em língua portuguesa) associado tanto aos artigos de gênero masculino como de gênero feminino. Para o presente artigo, optou-se por utilizar a palavra no gênero feminino.

\subsubsection{Breve histórico sobre Spin-offs}

Para iniciar o entendimento sobre o fenômeno das spin-off é importante que seja colocado um breve histórico desse fenômeno.

Segundo Luc et al (2002), o conceito de spin-off tornou-se amplo nos Estados Unidos nos anos de 1960, tendo como berço as empresas de tecnologia e universidades ao redor da região do Vale do Silício na Califórnia, quando tais entidades investiram seus esforços para criar 
unidades autônomas de produtos e soluções para ampliar sua capacidade de negócio e atingimento de mercado.

Entretanto, somente a partir dos anos de 1980, o fenômeno ganhou força e passou a ter uma abrangência maior para outros setores da economia que não o tecnológico (LUC et al, 2002). Uma das explicações para tal ebulição das spin-offs, é a crise que as grandes empresas norteamericanas enfrentam nessa década, principalmente devido à concorrência com empresas menores; "que conseguem entregar novos produtos e serviços de maneira mais eficiente e barata" (THORNBERRY, 2003, p. 330).

Apesar dessa maior evidência a partir da segunda metade dos anos 1900, Garvin (1983) afirma que esse fenômeno era muito comum na aurora da indústria automotiva nos Estados Unidos, que se deu por volta de 1920. Klepper (2009), corrobora essa afirmação ao evidenciar que somente sete montadoras de carros nos Estados Unidos, produziram pelo menos 3 spinoffs entre 1900 e 1924; totalizando 35 novas empresas no total.

Na França, desde os anos de 1980, a legislação vigente favorece o surgimento de spin-offs corporativas, dado a proteção que oferece uma licença aos funcionários que queiram criar uma nova empresa. Devido a tais licenciamentos, estima-se que em 2002 foram criadas de 15.000 a 20.000 novas empresas por meio de spin-offs (LUC et al, 2002).

\subsubsection{Definição de Spin-offs}

A presente seção tem como objetivo esclarecer o que é Spin-off, qual a sua relevância em termos de negócios e estabelecer quais definições são mais aderentes ao estudo conduzido.

Foram pesquisadas bases de dados diversas através da ferramenta Google Acadêmico (Google Scholar) que provê acesso a várias bibliotecas e repositórios de artigos de revistas, universidades e centros de pesquisa.

Sobre esse ponto Clarysse et al (2005), defendem que apesar da sua relevância como ferramenta de inovação e crescimento econômico, ainda há pouco conhecimento detalhado sobre o fenômeno das Spin-off. 
Para iniciar a discussão, faz-se necessário estabelecer a definição do que é Spin-off. Com o objetivo de trazer uma definição ampla e imparcial, foram buscadas algumas definições prévias para construir àquela que melhor sirva ao contexto do presente trabalho.

A Tabela a seguir traz as definições de alguns autores sobre o que é Spin-off:

Tabela 5 - Definições de Spin-off

\begin{tabular}{|c|c|c|c|}
\hline DEFINIÇÃO & AUTOR & ANO & TÍTULO DA OBRA \\
\hline $\begin{array}{l}\text { Novas empresas criadas por indivíduos, que se } \\
\text { separam de empresas existentes, estabelecendo } \\
\text { um novo competidor autônomo - é muito } \\
\text { comum em empresas de alta tecnologia e outras } \\
\text { também }\end{array}$ & GARVIN & 1983 & $\begin{array}{l}\text { Spin-offs and the New } \\
\text { Firm Formation Process }\end{array}$ \\
\hline $\begin{array}{l}\text { Na sua expressão mais simples, o spin-off de } \\
\text { empresas pode ser concebido como um } \\
\text { conjunto de atividades implementadas por uma } \\
\text { empresa, a fim de ajudar um de seus } \\
\text { assalariados, ou um grupo de empregados, } \\
\text { interessados em criar uma nova empresa. }\end{array}$ & LUC et al & 2002 & $\begin{array}{l}\text { Guia de Spin-off de } \\
\text { empresas: Em direção a } \\
\text { novas formas de práticas } \\
\text { empresariais }\end{array}$ \\
\hline $\begin{array}{l}\text { Formação de novos negócios com base em } \\
\text { ideias de negócios originadas em uma empresa } \\
\text { mãe, porém sendo desenvolvidas em uma } \\
\text { empresa independente. }\end{array}$ & $\begin{array}{l}\text { PARHANKANGAS; } \\
\text { ARENIUS }\end{array}$ & 2003 & $\begin{array}{l}\text { From a corporate venture } \\
\text { to an independent } \\
\text { company: a base for a } \\
\text { taxonomy for corporate } \\
\text { spin-off firms }\end{array}$ \\
\hline $\begin{array}{l}\text { Processos de formação de novas empresas a } \\
\text { partir de outras existentes. }\end{array}$ & COZZI et al & 2006 & $\begin{array}{l}\text { Relatório de Pesquisa: } \\
\text { Projeto Spin-offs } \\
\text { corporativos }\end{array}$ \\
\hline $\begin{array}{l}\text { Uma entidade legal separada que é concentrada } \\
\text { nas atividades que foram originalmente } \\
\text { desenvolvidas em uma grande empresa mãe; a } \\
\text { entidade é concentrada em novos negócios, } \\
\text { com o propósito de desenvolver e comercializar } \\
\text { novos produtos ou serviços baseados em uma } \\
\text { tecnologia proprietária ou habilidades únicas }\end{array}$ & $\begin{array}{l}\text { VAN DE VELDE; } \\
\text { CLARYSSE }\end{array}$ & 2006 & $\begin{array}{l}\text { A Model of Antecedents } \\
\text { and Characteristics of } \\
\text { Corporate Spin-offs }\end{array}$ \\
\hline $\begin{array}{l}\text { Criação de novas empresas baseadas na } \\
\text { transferência - formal e informal - de } \\
\text { tecnologia gerada por centros públicos de } \\
\text { pesquisa }\end{array}$ & MUSTAR et al & 2006 & $\begin{array}{l}\text { Conceptualising the } \\
\text { heterogeneity of research- } \\
\text { based spin-offs: A multi- } \\
\text { dimensional taxonomy }\end{array}$ \\
\hline $\begin{array}{l}\text { Novas empresas fundadas por empregados de } \\
\text { empresa incumbentes - podendo ser chamado } \\
\text { de spin-off ou spin-out }\end{array}$ & KLEPPER & 2009 & $\begin{array}{l}\text { Spinoffs: A review and } \\
\text { synthesis }\end{array}$ \\
\hline
\end{tabular}


Nota-se que o conceito de Spin-off evoluiu com o passar dos anos. Enquanto em Garvin (1983) há uma ênfase na questão do ex-funcionário empreendedor, as definições mais recentes buscam trazer uma posição mais holística e orientada ao resultado dos negócios.

Tal posição é corroborada por Clarysse et al (2011) que complementa a definição ao indicar que o foco de uma spin-off é desenvolver novos produtos, serviços ou mercados que porventura não eram atrativos ou possíveis de atuação pela empresa mãe.

Com base nessas definições prévias, pode-se afirmar que Spin-off é uma empresa estabelecida a partir de uma já existente e que desenvolve novos produtos e/ou serviços. Podendo ser esses ligados ou não à atividade da empresa mãe.

É importante ressaltar que esse fenômeno, ou forma de gestão, não é algo exclusivo da realidade empresarial, sendo muito comum no meio acadêmico.

Ademais, as Spin-offs acadêmicas - ou institucionais - são mais simples de serem estudadas; pois enquanto para essas empresas (acadêmicas e institucionais) há maior disponibilidade de casos e informações, nas empresas corporativas as informações são restritas e não há dados que permitam diferenciá-las de startups comuns. (COZZI et al, 2006; FERRAZ; TEIXEIRA, 2014).

\subsubsection{Diferença Entre Spin-offs Corporativas E Acadêmicas}

Conforme mencionado acima, o fenômeno das spin-offs é algo que ocorre tanto na realidade das empresas como em instituições de ensino e pesquisa, a esse segundo grupo é dado o nome de spin-off acadêmicas.

Considerando que o objetivo do presente trabalho é abordar a realidade corporativa, não será aprofundado o estudo sobre as spin-off acadêmicas. Entretanto, é relevante pontuar as principais diferenças entre esses dois tipos de empresa.

As spin-offs acadêmicas são empresas originadas em universidades ou centro de pesquisas e têm como objetivo viabilizar a exploração comercial de tecnologias desenvolvidas pelos 
pesquisadores. Na Europa e nos Estados Unidos, é uma das principais formas de transferir o conhecimento gerado nas universidades para a sociedade.

Diferente das spin-offs corporativas, onde há acesso a conhecimento de gestão de negócios, as spin-offs acadêmicas possuem grande especialização nas tecnologias e competências que compõe o diferencial do novo empreendimento.

A Tabela a seguir, busca pontuar as principais diferenças entre spin-offs acadêmicas e spinoffs corporativas.

Tabela 6 - Diferença entre spin-offs corporativas e acadêmicas

\begin{tabular}{|l|l|l|}
\hline \multicolumn{1}{|c|}{ CARACTERÍSTICA } & SPIN-OFF CORPORATIVA & \multicolumn{1}{|c|}{ SPIN-OFF ACADÊMICA } \\
\hline Motivação & $\begin{array}{l}\text { Exploração de novos produtos } \\
\text { ou mercados. Busca de } \\
\text { eficiência operacional. }\end{array}$ & $\begin{array}{l}\text { Exploração mercadológica de } \\
\text { produtos erviços } \\
\text { desenvolvidos em faculdades e } \\
\text { centros de pesquisa }\end{array}$ \\
\hline Propriedade & $\begin{array}{l}\text { Empresa mãe. Eventualmente } \\
\text { outras empresas e sócios. }\end{array}$ & $\begin{array}{l}\text { Pesquisadores. Eventualmente a } \\
\text { instituição têm algum tipo de } \\
\text { participação }\end{array}$ \\
\hline Acesso à capital & Próprio ou de terceiros & $\begin{array}{l}\text { Geralmente conta com o apoio de } \\
\text { fundos de investimento ou dos } \\
\text { próprios pesquisadores }\end{array}$ \\
\hline Nível de gestão & Alto. Segue o modelo de gestão \\
da empresa mãe. & $\begin{array}{l}\text { Geralmente baixo. Depende } \\
\text { muito da capacidade de gestão } \\
\text { dos pesquisadores envolvidos } \\
\text { no projeto da spin-off }\end{array}$ \\
\hline
\end{tabular}

\subsubsection{Relevância das spin-offs corporativas}

Conforme a tabela acima a principal motivação para que uma empresa invista em um novo negócio via spin-off pode ser por necessidade de mercado ou operacional. Entretanto, outros benefícios podem ser gerados pela criação de uma spin-off. Entre os benefícios trazidos com 
sua criação podemos destacar: a possibilidade de exploração de novos negócios (sob a visão da empresa mãe), a possibilidade de um funcionário se tornar um empresário e investir em seu próprio negócio (visão do empregado/empreendedor), transferência de tecnologia para a sociedade de forma comercial (visão de instituições ou universidades), geração de novos empregos/ampliação da dinâmica econômica (visão dos agentes governamentais). (COZZI et al, 2006; LUC et al, 2002; CLARYSSE et al, 2005).

\subsubsection{Spin-offs como exploração de novos negócios}

Antes de abordar diretamente as spin-offs corporativas como uma forma exploração de novos negócios, é importante estabelecer uma breve definição de como um novo negócio se insere no contexto estratégico das empresas.

Roberts e Berry (1984), apresentam alternativas de crescimento para as empresas que partem de duas frentes principais:

1) Expansão dos Negócios existentes: quando a empresa deseja investir em produtos, tecnologias ou mercados que já atua ou que possui grande conhecimento e domínio.

2) Diversificação - também chamado de Novos Negócios - opção que ocorre quando a empresa deseja investir em negócios em que ela desconhece o mercado, a tecnologia ou o produto desse (novo) empreendimento.

A partir dessas duas alternativas há uma ramificação das estratégias de crescimento que pode ser resumida pela ilustração a seguir: 


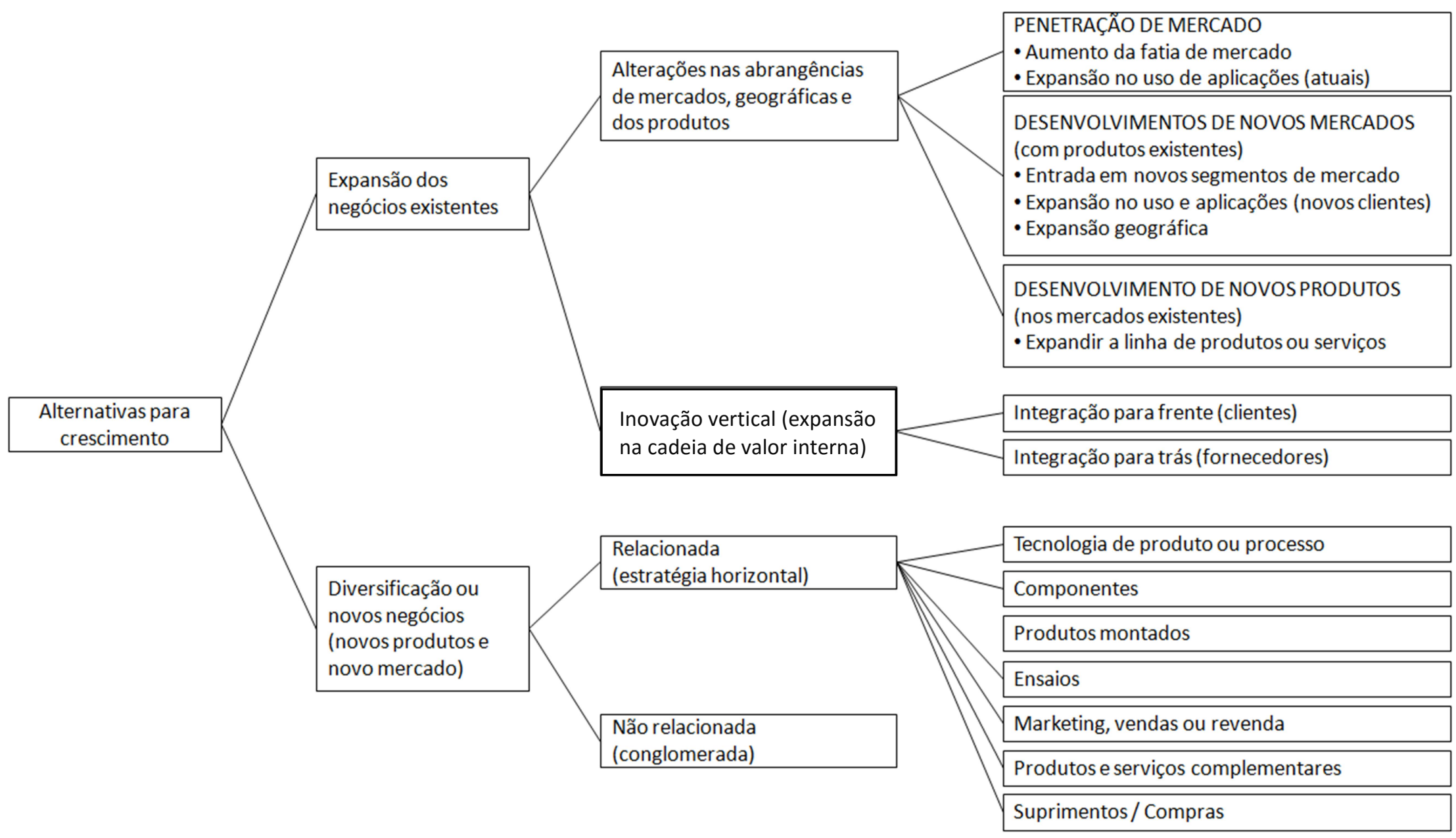

Ilustração 12 - Estratégias de Crescimento

FONTE: ROBERTS; BERRY, 1984 (Adaptado). 
Quando se analisa especificamente a forma de ingresso em novos negócios (diversificação), o mesmo autor apresenta 7 mecanismos de desenvolvimento / entrada em novos negócios, bem como as vantagens e desvantagens de cada um. Abaixo seguem essas sete opções descritas por Roberts e Berry (1984):

Desenvolvimento Interno: quando a empresa explora seus recursos internos como base para a criação do novo negócio. O autor ressalta que a performance (em termos de Payback e Retorno sobre o Investimento (ROI)) desse tipo de novo negócio é inferior à de negócios criados por empreendedores independentes. A possível explicação dada para tal, é a ambição e agressividade de objetivos para os empreendedores independentes que, eventualmente, buscam resultados de curto prazo; sendo o inverso para as empresas que desenvolvem novos negócios.

Aquisição: é o oposto ao desenvolvimento interno. É uma abordagem que requer menos tempo para se concretizar (quando comparada ao Desenvolvimento Interno) e pode também apresentar menor custo de entrada no negócio, principalmente quando o principal atrativo desse novo empreendimento for algo intangível como marca, patente ou know how específico.

Licenciamento: trata-se da aquisição de tecnologia mediante parcerias e licenças sendo, portanto, uma alternativa à aquisição de uma empresa completa.

Empreendimento Interno (Internal Venturing): semelhante ao Desenvolvimento Interno, com a diferença que é estabelecida uma nova entidade totalmente distinta da empresa principal. Há o desafio de conciliar duas "culturas" diferentes; de uma empresa jovem e ambiciosa e de uma empresa estabelecida e madura.

Joint ventures ou alianças: é a união de uma ou mais empresas para explorar o novo empreendimento. É uma opção comumente utilizada quando os riscos e custos envolvidos no desenvolvimento do novo negócio são altos.

Capital de Risco e Incubação: trata-se de investir financeiramente em outra empresa (geralmente menor que a empresa principal) no desenvolvimento de novas tecnologias, produtos ou mercados. Permite a empresa não se envolver operacionalmente com o novo 
negócio, porém colher frutos de sua exploração. Quando há a transferência de capacidade de gestão ao invés de capital financeiro somente, é considerado como Incubação.

Aquisição "Educacional": são as aquisições com o objetivo de captar o know how desenvolvido pelas pessoas que dominam determinada tecnologia ou mercado. Roberts e Berry (1984) pontuam que apesar de ser algo pouco explorado pelos estudos acadêmicos, é uma opção que pode proporcionar benefícios de curto prazo uma vez que as novas pessoas podem provocar mudanças significativas na empresa mãe.

A Tabela abaixo apresenta as vantagens e desvantagens de cada mecanismo na visão de Roberts e Berry (1984).

Tabela 7 - Mecanismos de Ingresso em um novo negócio

\begin{tabular}{|c|c|c|}
\hline $\begin{array}{c}\text { MECANISMO DE } \\
\text { DESENVOLVIMENTO / } \\
\text { ENTRADA NO NEGÓCIO }\end{array}$ & VANTAGENS & DESVANTAGENS \\
\hline Desenvolvimento Interno & Utilizar recursos existentes & $\begin{array}{l}\text { Custo de aprendizado e tempo para } \\
\text { desenvolvimento. A falta de familiaridade } \\
\text { com novos mercados pode levar a erros }\end{array}$ \\
\hline Aquisição & Rápida entrada no mercado & O novo negócio pode não ser familiar \\
\hline Licenciamento & $\begin{array}{l}\text { Rápido acesso à tecnologia } \\
\text { viável. Redução do risco de } \\
\text { exposiçâ financeira }\end{array}$ & $\begin{array}{l}\text { Dependência do fornecedor de licença. } \\
\text { Tecnologia não proprietária. Não é um } \\
\text { substituto para competência técnica. }\end{array}$ \\
\hline Internal Venturing & $\begin{array}{l}\text { Utilizar recursos existentes. } \\
\text { Permite a empresa manter } \\
\text { talentos empreendedores }\end{array}$ & $\begin{array}{l}\text { Histórico de sucesso misto. O clima na } \\
\text { corporação é frequentemente inadequado. }\end{array}$ \\
\hline Joint ventures ou alianças & $\begin{array}{l}\text { Minimizam os riscos } \\
\text { combinando competências de } \\
\text { empresas complementares }\end{array}$ & Potencial para conflito entre parceiros \\
\hline Capital de Risco e Incubação & $\begin{array}{l}\text { Pode fornecer uma janela de } \\
\text { mercado ou nova tecnologia }\end{array}$ & $\begin{array}{c}\text { Improvável que sozinho seja um estímulo } \\
\text { para o crescimento da corporação. }\end{array}$ \\
\hline Aquisições Educacionais & $\begin{array}{l}\text { Fornecem uma janela inicial } \\
\text { de mercado e staff }\end{array}$ & $\begin{array}{l}\text { Elevado comprometimento inicial } \\
\text { financeiro em comparação com o capital de } \\
\text { risco. Risco de saída dos empreendedores }\end{array}$ \\
\hline
\end{tabular}

FONTE: ROBERTS; BERRY, 1984, p. 11 (Adaptado).

Dessas categorias, é possível estabelecer que as spin-offs se enquadram como Internal Venturing pois, segundo Roberts e Berry: 
Nessa estratégia de empreendimento, uma empresa almeja entrar em diferentes mercados ou desenvolver produtos substancialmente diferentes daqueles existentes no seu negócio base, mediante estabelecimento de uma entidade separada da sua estrutura empresarial. (ROBERTS; BERRY, 1984, p. 13).

Na Tabela acima, Roberts e Berry (1984) apresentam que as iniciativas de Internal Venturing têm como desvantagem o "sucesso misto". Entretanto, uma pesquisa de Porter (1996) que avaliou o sucesso de diversificação de 33 empresas norte americanas, indicou que as práticas com melhor taxa de sucesso tinham as seguintes características:

(i) tinham como estratégias corporativas direcionadoras: negócios em que ocorre transferência de competências a negócios que compartilham atividades entre si;

(ii) embora a aquisição fosse a estratégia de entrada mais utilizada, o desenvolvimento próprio é o que teve a maior taxa de sucesso;

(iii) o portfólio de investimentos era planejado;

(iv) o processo de desenvolvimento de novos negócios era fortemente sistematizado e analítico.

É possível fazer uma relação entre os quatro fatores descritos por Porter e as características das spin-offs, indicando, portanto, que esse tipo de empreendimento tem elementos que influenciam de forma positiva em sua performance.

\subsubsection{A Relação entre spin-off e empresa mãe}

Outra característica das spin-offs que favorecem seu desenvolvimento, é permitir à empresa mãe viabilizar as oportunidades de empreender de maneira distinta, sem concorrência com o seu foco que é justamente manter a operação principal em funcionamento de maneira eficiente.

As vantagens de se investir em spin-offs se dá principalmente quando se investe em negócios no mesmo ramo de atividade da empresa mãe, o que Garvin (1983), define como intra spinoff.

As referidas vantagens que se tem nesse tipo de spin-off é decorrente de alguns fatores, tais como os descritos abaixo por Luc et al (2002): 
(i) Domínio de tecnologias inovadoras inerentes ao ramo de atuação

(ii) Possibilidade de migração de recursos humanos com conhecimentos específicos

(iii) Compartilhamento (entre empresa mãe e spin-off) da rede de relacionamentos fundamentais ao negócio

(iv) Ganhos tributários ou econômicos

(v) Maximizar o uso de ativos.

Nota-se que mesmo sendo unidades autônomas, as vantagens acima são decorrentes do relacionamento entre empresa mãe e a nova companhia. Tal relacionamento pode conter vários graus de compartilhamento de recursos entre as duas entidades. $\mathrm{O}$ entendimento das causas, formas de funcionamento e consequências da relação entre empresa mãe e spin-off é um dos aspectos mais amplamente abordados pelas pesquisas acadêmicas, o que se pode verificar nos trabalhos de Parhankangas e Arenius, 2003; Luc et al, 2002; Clarysse et al, 2005; Ferraz e Teixeira, 2014; Van de Velde e Clarysse, 2006 e de vários outros.

Parhankangas e Arenius (2003), indicam que as spin-offs podem ter três configurações principais de acordo com o objetivo de sua criação. De modo que para cada uma dessas configurações, a relação entre a empresa mãe a spin-off terá características distintas. Tais configurações são: Nova Tecnologia, Novo Mercado e Reestruturação.

A Tabela a seguir, apresenta um quadro geral dessas configurações, a forma como se dá a relação empresa mãe e spin-off e outros aspectos importantes do negócio. 
Tabela 8 - Tipos de spin-off e a relação com a empresa mãe

TIPOS DE SPINOFF DE ACORDO COM O TIPO DE RELACIONAMENTO

\begin{tabular}{|c|c|c|c|c|}
\hline TIPO & Nova Tecnologia & \multicolumn{2}{|c|}{ Novo Mercado } & Reestruturacão \\
\hline $\begin{array}{l}\text { PRINCIPAL } \\
\text { CARACTERÍSTICA }\end{array}$ & $\begin{array}{l}\text { Desenvolver produtos ou } \\
\text { serviços inovadores }\end{array}$ & \multicolumn{2}{|c|}{$\begin{array}{l}\text { Mesma tecnologia da empresa mãe, porém atendem } \\
\text { mercados distintos }\end{array}$} & $\begin{array}{l}\text { Unidades de negócio focadas em um } \\
\text { determinado processo ou etapa da cadeia da } \\
\text { empresa mãe }\end{array}$ \\
\hline MERCADO & Mercado Inexistente & $\begin{array}{l}\text { a. Empresa mãe } \\
\text { (diferencial } \\
\text { competitivo) }\end{array}$ & $\begin{array}{l}\text { b. Mercado existente não } \\
\text { explorado pela empresa mãe }\end{array}$ & $\begin{array}{l}\text { Mercados específicos inerentes à atividade da } \\
\text { U.N }\end{array}$ \\
\hline $\begin{array}{l}\text { RELAÇÃO EMPRESA } \\
\text { MÃE X SPIN-OFF }\end{array}$ & $\begin{array}{l}\text { A spin-off é geralmente } \\
\text { uma área, equipe de projeto } \\
\text { específico ou unidade de } \\
\text { negócio DENTRO da } \\
\text { empresa mãe }\end{array}$ & $\begin{array}{l}\text { Compartilhamento de } \\
\text { tecnologia, processos e } \\
\text { conceitos de design de } \\
\text { seus produtos e serviços } \\
\text { para a spin-off }\end{array}$ & $\begin{array}{llr}\text { Igual acima. } & \text { Porém a } \\
\text { empresa mãe não } & \text { consegue } \\
\text { atender de } & \text { maneira } \\
\text { satisfatória a necessidade dos } \\
\text { novos clientes } & \text { explorados } \\
\text { pela spin-off } & \end{array}$ & $\begin{array}{l}\text { Relação muito próxima. Prestação de serviço, } \\
\text { execução de processo, desenvolvimento de } \\
\text { melhorias e tecnologias. }\end{array}$ \\
\hline $\begin{array}{l}\text { MOTIVADOR } \\
\text { SPIN-OFF }\end{array}$ & $\begin{array}{l}\text { Reestruturação conduzida } \\
\text { pela empresa mãe } \\
\text { dificuldade em manter uma } \\
\text { tecnologia (UN) que não } \\
\text { tem mercado. }\end{array}$ & $\begin{array}{l}\text { Expansão da base de } \\
\text { clientes para justificar } \\
\text { ganhos de produtividade }\end{array}$ & $\begin{array}{l}\text { A empresa mãe não tem } \\
\text { interesse em investir na spin- } \\
\text { off para diversificação nos } \\
\text { novos mercados }\end{array}$ & $\begin{array}{l}\text { Reestruturação da empresa mãe para reinventar } \\
\text { suas vantagens competitivas em um estágio } \\
\text { maduro de sua existência. }\end{array}$ \\
\hline \begin{tabular}{lr} 
RELAÇÃO & \multicolumn{2}{c}{ ENTRE } \\
EMPRESAS & APÓS O \\
SPIN-OFF &
\end{tabular} & $\begin{array}{l}\text { A relação } \quad \text { permanece } \\
\text { estreita. O fato de } \\
\text { eventualmente criar-se um } \\
\text { novo mercado ao redor da } \\
\text { spin-off pode inclusive } \\
\text { motivar a reabsorção da } \\
\text { spin-off }\end{array}$ & $\begin{array}{l}\text { A empresa mãe vira acion } \\
\text { Em alguns casos, o o } \\
\text { justamente atrair parceiro }\end{array}$ & $\begin{array}{l}\text { nista de uma parte da spin-off } \\
\text { objetivo da empresa mãe é } \\
\text { s para dividir o risco }\end{array}$ & $\begin{array}{l}\text { Quase nula em termos de compartilhamento de } \\
\text { processos. A spin-off tem grande autonomia e } \\
\text { geralmente possui bons resultados de negócio. }\end{array}$ \\
\hline
\end{tabular}

(continua na próxima página) 


\begin{tabular}{|l|l|l|l|l|}
\hline \multicolumn{1}{|c|}{} & \multicolumn{3}{|c|}{ TIPOS DE SPINOFF DE ACORDO COM O TIPO DE RELACIONAMENTO } \\
\hline TIPO & Nova Tecnologia & \multicolumn{2}{|c|}{ Novo Mercado } & Reestruturação \\
\hline $\begin{array}{l}\text { CAPACIDADE DE } \\
\text { EXPLORAR NOVOS } \\
\text { PRODUTOS } \\
\text { SERVIÇOS }\end{array}$ & $\begin{array}{l}\text { E } \\
\text { Muito baixo - Geralmente a a } \\
\text { spin-off serve a interesses } \\
\text { da empresa mãe }\end{array}$ & $\begin{array}{l}\text { Moderado - As spin-off } \\
\text { podem inclusive vender } \\
\text { os produtos e serviços } \\
\text { para concorrentes da } \\
\text { empresa mãe }\end{array}$ & $\begin{array}{l}\text { Muito alta - a spin-off foi } \\
\text { concebida com essa missão }\end{array}$ & $\begin{array}{l}\text { Muito Alta - O desafio de desenvolver } \\
\text { melhorias em processos, produtos e serviços; } \\
\text { permite à spin-off explorar diferentes opções de } \\
\text { mercado }\end{array}$ \\
\hline
\end{tabular}

FONTE: PARHANKANGAS; ARENIUS, 2003 (Adaptado). 


\subsection{Modelos de planejamento de Novos Negócios}

A intenção inicial do autor era identificar, na literatura existente, materiais sobre o planejamento de spin-off corporativas. Foram consultadas as seguintes bases: ProQuest, Ebsco (EbscoHost), Periódicos CAPES e Google Acadêmico (scholar.google.com).

Entretanto, não foram localizados artigos que abordam o tema sob esse enfoque do planejamento e etapas de implantação. Os trabalhos encontrados se aprofundam em abordagens como: a relação entre empresa mãe e spin-off, a diferença entre spin-offs corporativas e acadêmicas, comparação de desempenho de spin-offs corporativas com outros tipos de empresas e os impactos no mercado de ações das iniciativas de spin-offs.

Dessa forma, para prosseguir com a pesquisa, o autor optou por entender o planejamento de novos negócios a partir de agências fomentadoras reconhecidas e de ampla atuação. Essa abordagem tem aderência à experiência do autor e contribuirá para a entrega de um material atual e prático para empresas interessadas em investir, inovar e crescer mediante a criação de uma spin-off.

Serão esquematizadas as orientações de duas entidades promotoras do empreendedorismo. Considerando que os guias/modelos estudados são de uso amplo genérico tanto para empreendedores novos como para aqueles com alguma experiência, o autor trouxe ao presente trabalho apenas os aspectos, seções e temas que são relevantes para a realidade de empresas já estabelecidas e, portanto, a realidade de spin-offs corporativas.

Foram escolhidas as seguintes entidades para estudo:

SEBRAE - (Serviço Brasileiro de Apoio às Micro e Pequenas Empresas), principal órgão brasileiro de suporte aos empreendedores e pequenos empresários.

SBA - Small Business Administration ou Administração de Pequenos Negócios -autarquia federal norte americana, de atuação independente, e que existe para auxiliar, aconselhar e proteger os interesses dos pequenos negócios nos Estados Unidos. Essa autarquia defende que 
os pequenos negócios são fundamentais para o desenvolvimento da sociedade e economia americana.

A escolha desses dois modelos se deu para permitir uma visão ampla e multicultural sobre o tema. Com isso é esperado que haja uma contribuição que considere as melhores práticas em diferentes países.

A seção está estruturada da seguinte forma:

1) Resumo dos modelos de planejamento de novos negócios

Nessa parte o autor comparou os dois guias e buscou alinhar as similaridades entre eles de modo a estabelecer uma base comum.

2) Explicação dos itens dos guias

Baseado no resumo criado, será exposto como cada uma das instituições explica os itens do guia e quais os elementos cruciais dos mesmos.

\subsubsection{Resumo dos modelos de planejamento de novos negócios}

Tanto o SEBRAE como a SBA disponibilizam de maneira livre e gratuita seus modelos de planejamento de novos negócios em seus portais da Internet. O SEBRAE fornece o arquivo "Como elaborar um Plano de Negócios" para download - sendo que a última versão disponível à época da pesquisa é do ano de 2013. A SBA por sua vez estruturou o guia no próprio site.

Ambas as entidades atribuem papel fundamental ao planejamento, como uma ferramenta que influencia positivamente o desempenho dos negócios, ao guiar o empreendedor nos elementos mais importantes do empreendimento.

Apesar de serem reconhecidas como agentes que promovem o empreendedorismo individual (voltado para as pessoas se lançarem como empresários) tanto o Sebrae como a SBA, ampliam o escopo de seus modelos de planejamento não só a esse tipo de empreendedor, mas também àqueles que estão a ampliar ou promover inovações em algum negócio já existente. 
Outra similaridade entre os dois modelos, é que ambos consideram o Plano de Negócios como um documento em constante mudança, não podendo, portanto, ser estático. É necessária constante revisão e adaptação face às eventuais mudanças que venham a surgir no decorrer da implantação do negócio.

A Tabela a seguir apresenta de forma simples os itens presentes em cada um dos dois modelos de planejamento e uma indicação se aquele item existe no plano do SEBRAE e no da SBA

Tabela 9 - Comparação Modelos de Negócio

\begin{tabular}{|r|c|c|}
\hline \multicolumn{1}{|c|}{ ITEM } & SEBRAE & SBA \\
\hline SUMÁRIO EXECUTIVO & TEM & TEM \\
\hline ANÁLISE DE MERCADO & TEM & TEM \\
\hline PLANO DE MARKETING & TEM & TEM \\
\hline PLANO FINANCEIRO & TEM & TEM \\
\hline PLANO OPERACIONAL & TEM & NÃO POSSUI \\
\hline CONSTRUÇÃO DE CENÁRIOS & TEM & NÃO POSSUI \\
\hline DESCRIÇÃO DA EMPRESA & NÃO POSSUI & NÃO POSSUI \\
\hline ORGANIZAÇÃO E GESTÃO & NÃO POSSUI & TEM \\
\hline PRODUTOS E SERVIÇOS & NÃO POSSUI & TEM \\
\hline INVESTIMENTOS & NÃO POSSUI & TEM \\
\hline
\end{tabular}

\subsubsection{Explicação dos itens dos modelos}

Abaixo, segue descrição dos itens de cada um dos modelos

\subsubsection{Sumário Executivo}

Resumo da estrutura do negócio. Deve enfatizar os seus pontos fortes, como se pretende atingir os objetivos e onde o empreendedor quer levar a empresa. Caso o empreendedor precise buscar financiamento ou investidores, essa seção será o "cartão de visita" para esses potenciais parceiros. Apesar de ser a primeira sessão do plano, deve ser a última a ser escrita. 
Deve-se contemplar a descrição das principais características pretendidas para a empresa, os produtos/serviços, mercados e clientes potenciais, estrutura societária, fonte de capital, premissas e expectativas financeiras (investimento necessário, faturamento, lucro, etc.) e expectativa de retorno de investimento (ROI, Payback).

O SBA recomenda duas abordagens distintas para empresas novas ou empresas já estabelecidas:

Para negócios já estabelecidos é recomendado que sejam inclusos os seguintes elementos:

a) Declaração de Missão da Empresa: parágrafo curto descrevendo qual a natureza e relevância do negócio.

b) Informação da empresa: tempo de atuação, quantidade de funcionários, descrição e função dos sócios e locais de atuação.

c) Dados de crescimento: informação sobre o crescimento da empresa, com destaques financeiros ou de mercado, como por exemplo, lucratividade, faturamento, fatia de mercado, etc. É recomendado o uso de gráficos e tabelas.

d) Produtos e Serviços: descrição dos principais produtos e serviços oferecidos pela empresa.

e) Informações financeiras: detalhamento sobre a situação financeira da empresa, como endividamento, característica do investimento, etc.

f) Resumo de planos futuros: explicar qual a expectativa para os próximos períodos do negócio.

Para novas empresas: na visão do SBA, as informações acima descritas são menos comuns para novos empreendedores, portanto, tais sujeitos devem utilizar o sumário executivo para expor o quanto entendem da indústria em que pretendem atuar-seja por experiência prática ou fruto de pesquisas - e como o negócio/solução vai endereçar alguma situação necessidade ou falha de mercado.

Para o SEBRAE é importante destacar estruturação dos sócios, desde a sua escolha até a atribuição de papéis e responsabilidades. Entre os pontos mais relevantes referentes à sociedade, pode-se destacar:

a) divisão clara de tarefas entre os sócios

b) definição dos valores de retirada dos sócios e como será a distribuição de lucros

c) definição do grau de autonomia de cada sócio 
d) escrever os potenciais pontos de atrito entre os sócios

Outro ponto que tem destaque no modelo de Planejamento do Sebrae, é a descrição da Missão da Empresa. Para a entidade, isso independe da maturidade do negócio ou não.

Como aspectos fundamentais na declaração de missão da empresa é enfatizado a menção à: descrição do negócio, identificação do consumidor, declaração do valor agregado [para o consumidor] com o negócio e o que é importante para funcionários, sócios, comunidade, etc.

O Sebrae também reforça que é importante mencionar a forma jurídica da empresa e do enquadramento tributário. É necessário que o empreendedor defina aqui o tipo de sociedade e se optará por tributação simples (imposto único) ou recolhimento de impostos e contribuições diversos. É recomendado que o empreendedor consulte um contador ou especialista em tributos para tomar essa decisão, visto que a opção de regime tributário está intimamente ligada à natureza da empresa e sua expectativa de faturamento anual.

\subsubsection{Análise de Mercado}

Para ambos os modelos de planejamento nessa seção é necessário mostrar conhecimento sobre a indústria e o mercado de atuação com o novo negócio.

Deve abordar três dimensões: Cliente, Concorrentes e Fornecedores. Abaixo, elementos fundamentais a constar na Análise de Mercado:

(i) Descrição da Indústria: descrição da indústria com suas características, maturidade, taxa de crescimento, perspectiva futura e grupos de clientes envolvidos.

(ii) Público Alvo: delimitação do mercado alvo para um tamanho que seja gerenciável e de fácil controle.

(iii) Perfil dos Clientes: identificar as necessidades cruciais dos clientes e indicar como elas são atendidas no momento. Incluir informações demográficas e a localização desses clientes. Estar atento ao comportamento sazonal e/ou cíclico de compras.

(iv) Tamanho do Mercado Alvo: entender a demanda atual do mercado alvo bem como seu potencial de crescimento para os próximos meses. É recomendado que sejam 
consultadas informações oficiais de institutos, agências e órgãos governamentais para subsidiar esse elemento com informações e dados.

(v) Market Share: indicar quanto do mercado alvo se espera atingir e quantos clientes captar. Mais importante que o número, é fundamentar a lógica para atingir aquele resultado.

(vi) Preço e Margem Alvo: Descrever o preço desejado, bem como a margem de cada produto.

(vii) Análise de Competitividade: Identificar a atuação dos concorrentes em termos de produto, serviço e público alvo. Considerar os pontos fortes e fracos, custos e riscos de entrada no mercado. Mensurar a melhor maneira de concorrer bem como as barreiras de entrada. Atentar-se para padrões de fabricação e/ou prestação de serviços, diferenciais que tornam o concorrente atraente aos olhos dos clientes. É recomendada uma reflexão para avaliar se de fato há espaço no mercado e/ou como a empresa deve se posicionar e que diferenciais oferecer para conseguir conquistar os clientes.

(viii) Restrições Legais: incluir as restrições existentes para atuar no mercado. Informar como as mesmas serão atendidas e, caso isso represente algum tipo de custo ou investimento específico, deve-se destacá-los.

(ix) Fornecedores: Conhecer os principais fornecedores que serão utilizados na criação dos produtos e serviços que serão vendidos. O guia reforça a necessidade de entender a capacidade de produção desses parceiros, seu padrão de qualidade bem como a relação dos mesmos com fornecedores.

\subsubsection{Plano de Marketing}

Nessa sessão devem ser descritas todas as ações necessárias para explorar o mercado alvo, comunicar-se com os potenciais clientes e efetivamente vender os produtos e serviços.

Com base nas informações recolhidas na análise de mercado, será possível identificar os potenciais clientes e quais as necessidades, com isso criar uma proposta de valor aderente e atrativa. Além disso, será possível estabelecer de forma precisa, como os mesmos serão sensibilizados a conhecer e adquirir os produtos e serviços do novo negócio 
É indicado que a estratégia cubra 4 pontos distintos: penetração de mercado, crescimento de mercado, canais de distribuição e comunicação.

Um aspecto importante mencionado, diz respeito à divulgação. É incluída nesse tópico a criação da Marca; considerando não somente os aspectos mercadológicos, mas também as questões burocráticas e legais, que envolvem o registro da marca e a pesquisa prévia para identificar se os nomes e marcas desejados para a empresa e seus produtos e serviços estão disponíveis no mercado.

Referente a vendas, é trazido a necessidade de definição clara das estruturas de comercialização, regras e canais de vendas; ou seja, quais as formas de entregar produto ou serviço para os clientes.

É abordada também a preocupação na escolha do local do negócio. Deve se considerar fortemente o tipo de negócio, principalmente se envolver atendimento ao público in loco ou entrega de mercadorias; bem como as condições de infraestrutura da região escolhida.

\subsubsection{Plano Financeiro}

Ambas as entidades indicam que essa seção só deve ser escrita após a análise de mercado e desenho dos planos de marketing e vendas.

Recomendam-se duas formas de trabalho para empresas maduras e incipientes, sendo que são formas complementares:

a) Histórico financeiro: para negócios maduros, o empreendedor deve trazer histórico de desempenho financeiro. Aqui cabem informações como: planilhas de resultados, orçamento, balanço de pagamentos, DRE, fluxo de caixa; para cada ano em que se está no negócio. Recomenda-se cobrir o espectro de três a cinco anos de atividades. Essas informações podem ser requeridas e são fundamentais especialmente quando se busca algum tipo de investimento ou financiamento externo.

b) Projeções Financeiras: seja um novo negócio ou uma empresa madura é esperado que sejam informadas as expectativas de receitas, despesas e investimentos. É fundamental que 
tais projeções estejam alinhadas com as expectativas de financiamento externo, caso seja previsto tal característica.

Abaixo os itens recomendados para as projeções; espera-se que o preenchimento dos itens pertinentes seja com o máximo de informações possíveis:

(i) Estimativa dos Investimentos Fixos: Listar o que se espera gastar com máquinas equipamentos, móveis, imóveis e veículos.

(ii) Capital de Giro: calcular o fluxo de caixa para funcionamento da empresa. Itens considerados: estoque, caixa mínimo, contas a pagar, contas a receber, liquidez esperada.

(iii) Investimentos Pré-Operacionais: todos os investimentos necessários para preparar a operação, tais como: reformas, treinamentos, taxas de registro, etc.

(iv) Investimento Total: soma resumida de todos os investimentos acima descritos, com especial atenção por parte do investidor/empreendedor da fonte dos recursos para iniciar o negócio.

(v) Estimativa de Faturamento Mensal: com base na avaliação do mercado, mais o preço a ser praticado, deve-se prever o quanto é esperado faturar com as vendas dos produtos ou serviços. Com isso é possível precificar os produtos mediante fixação da margem esperada sobre o custo do produto ou serviço.

(vi) Custo Unitário de Matéria Prima: trata-se de um custo variável. É algo exclusivo para industrias e considerar o custo de materiais utilizados na produção (embalagens, peças, partes, etc.).

(vii) Estimativa dos Custos de Comercialização: devem ser considerados todos os impostos envolvidos e também os valores previstos para comissões, bônus, propaganda, custos financeiros (emissão de boleto, cartão de crédito).

(viii) Custo Materiais Diretos ou de Mercadoria Vendida: é o custo de fabricação ou aquisição para venda do bem ou serviço. É um custo variável, portanto aumenta ou diminui seu valor em função do volume de produção ou vendas.

(ix) Custo com Pessoas: custo estimado com a folha salarial. Importante considerar não somente o valor do salário, mas também todos os encargos e impostos obrigatórios; bem como os benefícios que serão oferecidos.

(x) Custo com depreciação: depreciação de máquinas, equipamentos e móveis. 
(xi) Custo Fixo Operacional Mensal: devem ser calculados todos os custos que serão pagos independentemente do volume de produção ou vendas. Além dos salários e depreciações (calculados acima) devem ser considerados despesas com aluguel, limpeza, energia elétrica, etc. Outra linha de custo fundamental a ser considerada nesse cálculo é o pró-labore dos sócios.

(xii) Demonstrativo de Resultados (DRE) cálculo final com base em todas as estimativas de custos e receitas acima mencionados. Esse número indicará se a empresa funcionará com lucro ou prejuízo.

(xiii) Indicadores de Viabilidade: 4 indicadores que medem se o negócio é viável sobre diferentes aspectos:

a) Ponto de Equilíbrio: faturamento que a empresa precisa para pagar todas as suas despesas e custos. Pode ser calculado também em unidades vendidas.

b) Lucratividade (margem de lucro): indica o \% de lucro da empresa para cada unidade vendida ou valor monetário faturado.

c) Rentabilidade: mede o retorno do capital investido pelos sócios no negócio. Esse indicador indica quão atrativo o negócio é, pois, o número pode ser comparado com outras atividades ou mesmo outras empresas.

d) Prazo de retorno do investimento: outro indicador de atratividade. Demonstra quanto tempo o investidor demorará para recuperar o que investiu negócio

\subsubsection{Plano Operacional}

Essa seção é exclusiva do Modelo de Plano de Negócios do Sebrae. Engloba tudo que diz respeito a instalação do novo negócio e os processos necessários para o seu funcionamento. Nessa seção é definido também o plano de contratação de pessoas. Recomenda-se dividi-lo em 4 etapas:

O primeiro item é destinado a definir o layout do local da nova empresa. Nesse sentido, deve se considerar o melhor arranjo em termos de móveis, máquinas, equipamentos e fluxos de pessoas e atividades de modo a criar benefícios de uma estrutura bem montada.

Em seguida dois itens: capacidade produtiva e definição dos processos. Enquanto o primeiro é destinado a apresentar qual a melhor forma de utilizar os investimentos realizados e planos 
traçados, o segundo diz respeito ao desenho de processos necessários para que o negócio funcione e tenha êxito. É esperado que seja descrito cada um dos passos e atividades necessárias para que os produtos e serviços sejam criados e entregues aos clientes; bem como os recursos necessários para tal.

O quarto e último item da seção Operacional é o plano de contratação. Onde é reforçado apenas a importância de ter a quantidade de pessoas requeridas para o início da empresa e qual a qualificação desses colaboradores.

\subsubsection{Construção de Cenários}

Com o Plano de Negócios elaborado, é recomendado que sejam simulados diferentes cenários de performance do negócio. É recomendado a construção de três cenários: provável, otimista e pessimista. Para cada um deles, o empreendedor é convidado a traçar um plano de ação para se prevenir frente a adversidades ou aproveitar situações favoráveis. Outras recomendações incluem: (i) prever performance fraca nos primeiros meses, (ii) demora no início das atividades e (iii) eventuais gastos não previstos/orçados.

Esse item encontra-se presente apenas no manual do Sebrae.

\subsubsection{Avaliação Estratégica}

Outro item exclusivo ao modelo do Sebrae, o mesmo apresenta o conceito da matriz FOFA (ou SWOT) indicando que o objetivo é "detectar pontos fortes e fracos, com a finalidade de tornar a empresa mais eficiente e competitiva" (SEBRAE, 2013, p. 108).

Conceitualmente a matriz é apresentada como:

F (Forças): são características internas da empresa que apresentam vantagem competitiva perante os seus concorrentes

O (Oportunidades): Situações positivas do ambiente externo que influenciam em uma melhor performance à empresa 
F (Fraquezas): aspectos internos da empresa que a colocam em desvantagem perante os concorrentes

A (Ameaças): Situações externas, fora do controle dos responsáveis pelo negócio, e que podem colocar a empresa em situação de dificuldade.

\subsubsection{Organização e Gestão}

Item é exclusivo do modelo da SBA. Aqui devem ser inseridas todas as informações referentes à forma que a empresa está estruturada em termos de pessoas e/ou departamentos. É importante inserir informações detalhadas sobre o papel e responsabilidade dos principais tomadores de decisão; bem como a função de cada departamento (se for o caso). Ainda sobre os líderes é fundamental descrever a experiência e formação dessas pessoas; além da parte descritiva, considerar nessa seção as informações sobre salários e benefícios esperados para os colaboradores (de todos os níveis).

É recomendado que seja desenhado o organograma da empresa para demonstrar parte das informações requeridas acima; a mensagem a ser passada com isso, é que as principais funções da empresa estão sob a responsabilidade de alguém.

\subsubsection{Produtos e Serviços}

Também exclusiva ao modelo de planejamento do SBA, essa seção é destinada a expor com detalhes as informações sobre produtos e serviços que serão oferecidos pela empresa. Deve-se exaltar as características que o produto/serviço traz para atender as necessidades do mercado alvo, bem como os diferenciais que os tornam mais atrativos que os dos concorrentes.

Outro aspecto importante a ser considerado é o status de desenvolvimento do produto, se em pesquisa, produção, piloto, etc. Inclusive, informações sobre pesquisa e desenvolvimento que estejam em curso e que influenciem os produtos e serviços devem ser expostas, considerando a expectativa de tempo para serem agregadas ao negócio e como alterarão o desempenho do negócio. 
Devem ser listadas também patentes, e demais informações sobre direitos, marcas e acordos legais que possam impactar o negócio em seus produtos e serviços.

\subsubsection{Investimentos}

Caso o negócio tenha a necessidade de ser financiado por algum tipo de investimento externo, deve-se dedicar essa seção para descrever essas necessidades.

Pontos fundamentais:

a) A necessidade atual de investimento

b) Necessidade de investimento para os próximos três ou cinco anos

c) Detalhamento de como o investimento será utilizado (aquisição de equipamentos, financiar pesquisas, fluxo de caixa, etc.)

d) Previsões para o futuro financeiro do negócio que possam afetar a capacidade de pagamento, tais como: expectativa de sociedade, expectativa de venda do negócio ou parte dele, saída de sócios, negociações de dívidas.

Incluir também a forma que se espera o investimento e em quanto tempo espera pagar por ele.

\subsubsection{Outros itens nos modelos estudados}

Abaixo seguem alguns pontos que são abordados nos planos de negócio estudados, porém fora dos itens categorizados acima.

a) Clareza sobre o que o negócio oferece: o guia provoca o empreendedor a pensar na oferta "além" dos produtos e serviços; é orientado a pensar nas características que agregam valor à venda e tornam a empresa única na satisfação dos clientes.

b) Pensamento estratégico: É importante deixar claro o que está sendo vendido pela empresa. Não limitar a atuação da empresa, nesse sentido, pode ser prejudicial aos negócios, principalmente em seus estágios iniciais, fase onde os recursos são limitados; portando, foco é fundamental. 
c) Identificação de mercados a serem explorados: o guia define a criação de um nicho como "essencial para o sucesso" (SBA, 2016). O nicho pode ser estabelecido tanto pelo conhecimento do mercado de sócios e líderes, como a partir das pesquisas de mercado. Para identificar os nichos recomenda-se atenção à três pontos:

(i) Em que áreas ou elementos de mercado os competidores estão bem estabelecidos ou atendem de forma plena?

(ii) Que áreas ou elementos de mercado estão sendo ignorados pelos competidores?

(iii) Quais as potenciais oportunidades para os negócios?

d) Aparência: deve-se tomar cuidado com a aparência e organização do Plano de Negócios para que as ideias sejam expostas de forma clara e simples.

e) Utilidade: o Plano de Negócios deve ser a principal ferramenta para apresentação do negócio, podendo ser utilizado para obter novos parceiros, clientes, investidores e mesmo financiamentos. 


\section{ANÁLISE}

\subsection{Comparação entre os modelos}

Considerando ambos os casos expostos (experiência do autor) não existem elementos que possam definir os passos apresentados como um "modelo" replicável. Nota-se que a forma como as empresas foram planejadas, se deu muito mais como etapas de gerenciamento de um projeto, do que a elaboração de um Plano de Negócios em si.

De todo modo para efeitos da análise comparativa, os itens presentes nos modelos teóricos e as etapas dos projetos de implantação serão agrupados em "etapas" de acordo com a similaridade em sua descrição (no caso dos modelos teóricos) ou resultado gerado para o projeto (no caso da prática).

Por exemplo os itens: PLANO FINANCEIRO - que aparece tanto no modelo do SBA como no SEBRAE - e INVESTIMENTOS - que é exclusivo ao modelo do SBA -, serão agrupados e analisados em conjunto com a etapa CONSTRUÇÃO DO ORÇAMENTO E PLANEJAMENTO FINANCEIRO do projeto Flash, e também com o item PLANEJAMENTO FINANCEIRO do projeto Echo, de modo que foi nomeada a etapa PLANEJAMENTO FINANCEIRO para esse agrupamento.

Com base nessa lógica, abaixo segue ilustração que demonstra a estrutura de agrupamento e análise. Foram utilizadas cores para facilitar a visualização dos agrupamentos e os números indicam a ordem em que serão abordados na análise.

Após a Ilustração, cada uma das etapas é analisada de forma individual e ao final de todas as análises é apresentada uma proposta de Modelo de Negócios para Spin-Off Corporativas. 


\begin{tabular}{|c|c|c|c|c|c|c|c|}
\hline & & \multicolumn{4}{|c|}{ MODELO EM QUE APARECE } & \multicolumn{2}{|c|}{ AGRUPAMENTO } \\
\hline ITEM & BREVE DESCRIÇÃO & SEBRAE & SBA & $\begin{array}{c}\text { PROJETO } \\
\text { FLASH }\end{array}$ & $\begin{array}{l}\text { PROJETO } \\
\text { ECHO }\end{array}$ & ETAPA & NOME \\
\hline SUMÁRIO EXECUTIVO & $\begin{array}{l}\text { Resumo - Informações sobre a empresa, sócios, o } \\
\text { que se espera com o negócio, composição jurídica. } \\
\text { Produtos, mercado alvo, etc. } \\
\text { Descrição da empresa (mãe), dados de } \\
\text { crescimento, missão, visão e valores. } \\
\text { Estrutura societária }\end{array}$ & SIM & SIM & NÃO & NÃO & \multirow[t]{3}{*}{1} & \multirow{3}{*}{$\begin{array}{l}\text { SUMÁRIO } \\
\text { EXECUTIVO }\end{array}$} \\
\hline $\begin{array}{r}\text { CONCEPÇÃO } \\
\text { CONCEITUAL DO } \\
\text { NEGÓCIO }\end{array}$ & $\begin{array}{l}\text { Premissas do negócio. Direcionamentos sobre } \\
\text { estrutura da operação, restrições. }\end{array}$ & NÃO & NÃO & SIM & NÃO & & \\
\hline CONCEITO DO NEGOCIO & $\begin{array}{l}\text { Premissas do negócio. Direcionamentos sobre } \\
\text { estrutura da operação, restrições. }\end{array}$ & NÃO & NÃO & NÃO & SIM & & \\
\hline ANÁLISE DE MERCADO & $\begin{array}{l}\text { Conhecimento da industria e mercado, clientes } \\
\text { concorrentes e principais fornecedores. Definição } \\
\text { do mercado alvo, nicho, perfil de clientes, } \\
\text { precificação e ação da concorrência }\end{array}$ & SIM & SIM & NÃO & NÃO & \multirow[t]{2}{*}{2} & \multirow[t]{2}{*}{$\begin{array}{l}\text { ANÁLISE DE } \\
\text { MERCADO }\end{array}$} \\
\hline ANÁLISE DE MERCADO & $\begin{array}{l}\text { Entendimento do mercado baseado na experiência } \\
\text { dos executivos das empresas }\end{array}$ & NÃO & NÃO & NÃO & SIM & & \\
\hline $\begin{array}{r}\text { DEFINIÇÃO DE MODELO } \\
\text { DE NEGÓCIO E } \\
\text { ESTRATÉGIA DA } \\
\text { EMPRESA } \\
\end{array}$ & $\begin{array}{l}\text { BMG Canvas, definição dos principais processos e } \\
\text { dos processos e recursos a serem compartilhados } \\
\text { com a empresa-mãe }\end{array}$ & NÃO & NÃO & SIM & NÃO & \multirow{3}{*}{3} & \multirow{3}{*}{$\begin{array}{l}\text { MODELO DE } \\
\text { NEGÓCIO }\end{array}$} \\
\hline $\begin{array}{r}\text { VALIDAÇÃO DO MODELO } \\
\text { DE NEGÓCIO } \\
\end{array}$ & $\begin{array}{l}\text { Aprovação do negócio em forma estruturada. } \\
\text { Exposição da dimensão do projeto }\end{array}$ & NÃO & NÃO & SIM & NÃO & & \\
\hline $\begin{array}{r}\text { DEFINIÇÃO DE MODELO } \\
\text { DE NEGÓCIO }\end{array}$ & $\begin{array}{l}\text { BMG Canvas, definição dos principais processos e } \\
\text { dos processos e recursos a serem compartilhados } \\
\text { com a empresa-mãe }\end{array}$ & NÃO & NÃO & NÃO & SIM & & \\
\hline
\end{tabular}

(Continua na próxima página) 


\begin{tabular}{|c|c|c|c|c|c|c|c|}
\hline & & \multicolumn{4}{|c|}{ MODELO EM QUE APARECE } & \multicolumn{2}{|c|}{ AGRUPAMENTO } \\
\hline ITEM & BREVE DESCRIÇÃO & SEBRAE & SBA & $\begin{array}{c}\text { PROJETO } \\
\text { FLASH }\end{array}$ & $\begin{array}{l}\text { PROJETO } \\
\text { ECHO }\end{array}$ & ETAPA & NOME \\
\hline PLANO DE MARKETING & $\begin{array}{l}\text { Como atacar o mercado alvo, as ações de entrada } \\
\text { e de crescimento de mercado. } \\
\text { Definição dos canais de venda; definição de } \\
\text { marca, campanhas de comunicação, etc }\end{array}$ & SIM & SIM & NÃO & NÃO & 4 & MARKETING \\
\hline $\begin{array}{r}\text { ESTRUTURA DA } \\
\text { EMPRESA }\end{array}$ & $\begin{array}{l}\text { Definição de local para implantação do negócio, os } \\
\text { principais processos e equipe necessária }\end{array}$ & NÃO & NÃO & NÃO & SIM & \multirow{3}{*}{5} & \multirow{3}{*}{$\begin{array}{l}\text { ORGANIZAÇÃO } \\
\text { E GESTÃO }\end{array}$} \\
\hline $\begin{array}{r}\text { ORGANIZAÇÃO E } \\
\text { GESTÃO }\end{array}$ & $\begin{array}{l}\text { Estrututra da empresa, organograma, } \\
\text { departamentos, funções e responsabilidades. }\end{array}$ & NÃO & SIM & NÃO & NÃO & & \\
\hline PLANO OPERACIONAL & $\begin{array}{l}\text { Definições sobre os principais processos do } \\
\text { negócio. Local de instalação da empresa e plano } \\
\text { de contratação de pessoas. }\end{array}$ & SIM & NÃO & NÃO & NÃO & & \\
\hline $\begin{array}{l}\text { GOVERNANÇA } \\
\text { CORPORATIVA }\end{array}$ & $\begin{array}{l}\text { Definição detalhada dos recursos compartilhados, } \\
\text { bem como dos papéis e responsabilidades entre os } \\
\text { principais líderes das empresas. }\end{array}$ & NÃO & NÃO & NÃO & SIM & 6 & GOVERNANÇA \\
\hline PLANO FINANCEIRO & $\begin{array}{l}\text { Premissas financeiras, projeção de receitas, } \\
\text { investimentos, custos e despesas. } \\
\text { Informações sobre viablidade econômica do } \\
\text { projeto: ROI, Payback, Rentabilidade, etc }\end{array}$ & SIM & SIM & NÃO & NÃO & \multirow{4}{*}{7} & \multirow{4}{*}{$\begin{array}{l}\text { PLANEJAMENTO } \\
\text { FINANCEIRO }\end{array}$} \\
\hline $\begin{array}{r}\text { ORÇAMENTO E } \\
\text { PLANEJAMENTO } \\
\text { FINANCEIRO } \\
\end{array}$ & $\begin{array}{l}\text { Definição das expectativas de receitas e } \\
\text { investimentos e projeção para } 36 \text { meses. } \\
\text { Utilizou como base, os dados da empresa-mãe. }\end{array}$ & NÃO & NÃO & SIM & NÃO & & \\
\hline $\begin{array}{r}\text { PLANEJAMENTO } \\
\text { FINANCEIRO } \\
\end{array}$ & $\begin{array}{l}\text { Definição das expectativas de receitas e } \\
\text { investimentos e projeção para } 36 \text { meses. } \\
\text { Utilizou como base, os dados da empresa-mãe. }\end{array}$ & NÃO & NÃO & NÃO & SIM & & \\
\hline INVESTIMENTOS & Detalhar a necessidade de investimento externo. & NÃO & SIM & NÃO & SIM & & \\
\hline
\end{tabular}

(Continua na próxima página) 


\begin{tabular}{|c|c|c|c|c|c|c|c|}
\hline & & \multicolumn{4}{|c|}{ MODELO EM QUE APARECE } & \multicolumn{2}{|c|}{ AGRUPAMENTO } \\
\hline ITEM & BREVE DESCRIÇÃOO & SEBRAE & SBA & $\begin{array}{l}\text { PROJETO } \\
\text { FLASH }\end{array}$ & $\begin{array}{l}\text { PROJETO } \\
\text { ECHO }\end{array}$ & ETAPA & NOME \\
\hline $\begin{array}{r}\text { PLANEJAMENTO DO } \\
\text { PROJETO DE } \\
\text { IMPLANTAÇÃO }\end{array}$ & $\begin{array}{l}\text { Estruturação do projeto, com elaboração de } \\
\text { cronograma, atividades, responsáveis e demais } \\
\text { etapas para implantação da empresa e lançamento. }\end{array}$ & NÃO & NÃO & SIM & NÃO & \multirow{3}{*}{8} & \multirow{3}{*}{$\begin{array}{l}\text { PLANEJAMENTO } \\
\text { DO PROJETO }\end{array}$} \\
\hline $\begin{array}{r}\text { EXECUÇÃO DO PROJETO } \\
\text { DE IMPLANTAÇÃO } \\
\end{array}$ & Implantação do projeto & NÃO & NÃO & SIM & NÃO & & \\
\hline $\begin{array}{r}\text { PROJETO DE } \\
\text { IMPLANTAÇÃO }\end{array}$ & $\begin{array}{l}\text { Estruturação do projeto, com elaboração de } \\
\text { cronograma, atividades, responsáveis e demais } \\
\text { etapas para implantação da empresa e lançamento. }\end{array}$ & NÃO & NÃO & NÃO & SIM & & \\
\hline $\begin{array}{r}\text { ACOMPANHAMENTO DOS } \\
\text { RESULTADOS E } \\
\text { TRANSIÇÃO }\end{array}$ & Gestão do negócio e desenho do plano de transição & NÃO & NÃO & SIM & NÃO & A & $\begin{array}{l}\text { PLANO DE } \\
\text { TRANSIÇÃO }\end{array}$ \\
\hline $\begin{array}{r}\text { CONSTRUÇÃO DE } \\
\text { CENÁRIOS }\end{array}$ & $\begin{array}{l}\text { Desenho de cenários, com simulação de diferentes } \\
\text { perspectivas para o futuro do negócio. }\end{array}$ & SIM & NÃO & NÃO & NÃO & \multirow{2}{*}{ B } & \multirow{2}{*}{$\begin{array}{l}\text { AVALIAÇÃO } \\
\text { ESTRATÉGICA }\end{array}$} \\
\hline $\begin{array}{r}\text { AVALIAÇÃO } \\
\text { ESTRATÉGICA }\end{array}$ & Análise SWOT & SIM & NÃO & NÃO & NÃO & & \\
\hline PRODUTOS E SERVIÇOS & $\begin{array}{l}\text { Detalhamento de produtos e serviços que serão } \\
\text { oferecidos pela empresa. Incluir informações de } \\
\text { patentes ou de características únicas }\end{array}$ & NÃO & SIM & NÃO & NÃO & $\mathrm{C}$ & $\begin{array}{l}\text { PRODUTOS E } \\
\text { SERVIÇOS }\end{array}$ \\
\hline
\end{tabular}

Ilustração 13 - Agrupamento dos itens dos modelos para análise 
Sobre os três últimos itens agrupados do modelo: "A - PLANO DE TRANSIÇÃO”; "B AVALIAÇÃO ESTRATÉGICA" e "C - PRODUTOS E SERVIÇOS”, os mesmos foram classificados pelo autor como itens opcionais ao Plano de Negócios e, portanto, não seguem a ordem de numeração padrão estabelecida para os demais itens; sendo, portanto, tratados com adendo.

\subsection{Etapa 1: Sumário Executivo}

Fazem parte dessa etapa análise: (i) "Sumário Executivo" do Modelo SBA; (ii) "Sumário Executivo" do Modelo Sebrae; (iii) "Concepção Conceitual” do Negócio da empresa Flash; (iv) "Conceito do Negócio" da empresa Echo.

Considerando ambos os casos expostos (experiência do autor) não existem elementos que possam definir os passos apresentados como um "modelo" replicável. Nota-se que a forma como as empresas foram planejadas, se deu muito mais como etapas de gerenciamento de um projeto, do que a elaboração de um Plano de Negócios em si.

Entretanto, nota-se que o ponto de partida, seja na teoria com os dois modelos estudados como na experiência do autor, é uma descrição do negócio com as principais premissas, restrições, expectativas, motivação para criação daquele negócio etc. Em outras palavras parte-se da resposta para a pergunta: por quê o negócio está sendo criado.

Pensando especificamente na realidade de uma spin-off, essa pergunta (por que) é de extrema relevância. Pois ela vai determinar todos os demais aspectos específicos desse tipo de empresa, inclusive os pontos de relação entre a empresa mãe e a nova empresa; não só em termos de compartilhamento de recursos - conforme apresentado por Parhankangas e Arenius (2003) -, mas também de direcionamento estratégico, posicionamento de mercado e eventual cisão operacional.

Tanto no caso da Flash como da Echo, nessa etapa foram definidos e informados dados importantes que nortearam outras etapas do planejamento. Isso mostra uma das primeiras distinções da teoria com a prática; pois enquanto na teoria há um certo rigor com cada uma 
das fases do Plano de Negócios, a experiência prática mostrou que não há uma distinção se nessa primeira etapa está se definindo apenas uma introdução sobre o negócio ou diretrizes sobre outros aspectos como: mercado, forma de operação, etc.

\subsection{Etapa 2: Análise de Mercado}

Fazem parte dessa etapa de análise: (i) “Análise de Mercado" do Modelo SBA; (ii) "Análise de Mercado" do Modelo Sebrae; (iii) Análise de Mercado da empresa Echo.

Enquanto os dois modelos teóricos apresentam a Análise de Mercado como a segunda etapa do plano; a ocorrência foi detectada apenas no segundo exemplo de implantação estudado: a empresa Echo.

No caso Flash, tal item não foi considerado, dado o mercado da spin-off ser o mesmo da empresa mãe. De modo que não houve uma análise profunda desse aspecto, sendo consideradas as informações presentes na própria empresa mãe e na experiência dos executivos da empresa.

Entretanto, tal abordagem não deve ser incentivada pois pode levar a algum tipo de miopia estratégica ou mesmo de negligência à algum aspecto relevante do mercado. De modo que é seguro que seja dedicado uma seção do planejamento exclusiva para descrever (de forma clara e explícita) as informações de mercado, tendo um recorte específico para a realidade a ser explorada pela spin-off.

Nesse sentido, os itens apresentados nos modelos teóricos de planejamento, tanto do Sebrae como do SBA, apresentam uma estrutura consistente do que pode ser utilizado em sua integridade no planejamento de uma spin-off corporativa. 


\subsection{Etapa 3: Modelo de Negócio}

Fazem parte dessa etapa de análise: (i) "Definição do Modelo de Negócio e Estratégia da Empresa" da empresa Flash; (ii) "Validação do Modelo de Negócio" da empresa Flash; (iii) "Modelo de Negócio" da empresa Echo.

Os dois modelos teóricos de planejamento, não abordam o modelo de negócio de maneira direta e com essa definição. Porém nota-se que a estrutura de ambas entidades - SBA e Sebrae - incluem elementos presentes no BMG Canvas, que foi o modelo utilizado na implantação das duas spin-offs estudadas.

Entretanto, o uso do modelo Canvas, provou-se uma boa opção para demonstrar a estrutura do novo negócio para que os executivos das empresas mãe compreendessem, de forma clara, a estrutura do negócio. Aqui, novamente, nota-se uma particularidade de empresas estabelecidas: é fundamental que haja uma definição clara do modelo de negócio da spin-off para limitar o risco das pessoas envolvidas, avaliarem/julgarem o novo negócio com os hábitos, prerrogativas e costumes da empresa mãe.

Porém, é necessário habilidade e familiaridade com a ferramenta para que seu uso possa de fato criar uma visão transparente e correta da estrutura da empresa. $\mathrm{O}$ autor notou que durante a elaboração dos modelos de negócios de ambas as spin-offs, há uma tendência natural dos líderes envolvidos em fugir da proposta conceitual do BMG Canvas, principalmente com a proposta de itens que podem não fazer parte com a proposta de valor do negócio; de modo que é de suma importância que a condução das sessões seja realizada com rigor e foco. Eventualmente, uma explicação prévia sobre o que é a ferramenta, seu funcionamento e a forma de utilização pode ser uma alternativa para potencializar os resultados de sua utilização.

A particularidade encontrada no caso do projeto Flash, que inclui uma etapa específica de validação do modelo de negócio, pode ser considerada como uma característica desse projeto específico dado a necessidade de expor a dimensão do negócio e por ser a primeira vez que os dirigentes da empresa ALPHA tinham contato com a ferramenta BMG Canvas. Entende-se que qualquer que sejam as etapas ou entregas de planejamento de um novo negócio, as 
mesmas serão validadas com os principais interessados no projeto não sendo, portanto, necessário colocar as suas validações como fases de um modelo.

\subsection{Etapa 4: Marketing}

Fazem parte dessa etapa de análise: (i) "Plano de Marketing" do Modelo Sebrae;(ii) "Plano de Marketing" do Modelo SBA.

Em ambas as spin-offs implantadas pelo autor, não houve uma etapa específica para estruturar as formas de exploração do mercado. Entretanto considerando a natureza das spin-offs em questão essa estruturação existiu, pois foi justamente o motivador para criação de ambos os negócios.

No caso do Projeto Flash, como a intenção foi abordar o mesmo mercado da empresa mãe, inclusive com compartilhamento da base de clientes, o plano de marketing foi desenhado pela equipe de Marketing da empresa mãe, com adaptações das estratégias já utilizadas pela empresa principal fazendo aderência às necessidades do novo negócio.

No caso do Projeto Echo, não houve grande aprofundamento nesse tema além da premissa inicial de que a empresa deveria ter toda sua comunicação amplamente apoiada em comunicação digital. Por esse motivo a estratégia de marketing da spin-off deveria ser definida pelo executivo responsável pelo negócio, uma vez que tal profissional deverá ser um especialista nesse tipo de comunicação.

Em ambos os casos, a criação da marca, logotipo, etc. foi uma tarefa direcionada às equipes de Marketing da empresa mãe como uma atividade de projeto de implantação, de modo que o processo para criação dessa marca não foi algo acompanhado pelo autor enquanto responsável pelos projetos de implantação. A atuação do mesmo se deu juntamente com os dirigentes das empresas na validação/aprovação de opções apresentadas pelo departamento de marketing.

Apesar de, nas intervenções práticas, não ter sido considerado uma etapa para abordar o tema marketing, essa abordagem não deve ser encorajada para se evitar os mesmos riscos de pensar 
no novo negócio com vícios do negócio antigo ou uma limitação de entendimento das particularidades da spin-off.

\subsection{Etapa 5: Organização e Gestão}

Fazem parte dessa etapa de análise: (i) "Plano de Operacional" do Modelo Sebrae; (ii) “Organização e Gestão" do Modelo SBA (iii) "Estrutura da Empresa” da empresa Echo.

Apesar de ser demonstrado com nomes diferentes, essa seção é considerada por ambos os modelos teóricos.

No caso da prática, foi considerado como item de planejamento apenas no caso da agência Echo, sendo um dos temas que mais demandaram esforço do autor (enquanto responsável pelo planejamento da spin-off), principalmente no que confere ao desenho dos processos do negócio.

A utilização de benchmark, mediante imersão do autor, provou-se uma ferramenta valiosa para o desenho dos processos. Sabe-se que obter acesso à processos-chave de outro negócio pode ser uma tarefa inviável para a maioria dos casos de novos negócios, entretanto tal abordagem deve ser incentivada. Eventualmente, para superar tal limitação em termos de impossibilidade da obtenção de informações de empresas do mesmo mercado em que a spinoff planeja operar, os líderes do negócio/projeto podem buscar inspiração e ou modelos em empresas de outros países ou de mercado semelhantes.

\subsection{Etapa 6: Governança}

Faz parte dessa etapa de análise: (i) “Governança Corporativa” da empresa Echo.

Esse item que é presente apenas no planejamento da Echo, foi criado com base integral na experiência do autor com o primeiro projeto de implantação, onde houveram alguns conflitos e problemas de priorização, tomada de decisão e concorrência de recursos entre a empresa 
mãe e a spin-off por não estar devidamente claro quais os recursos compartilhados e como seria a estrutura de tomada de decisão entre os principais líderes do projeto.

Quando se observa a realidade de uma spin-off esse tema tem que ser tratado com atenção durante o planejamento do negócio pois a rede de compartilhamento de recursos, deve ampliar o potencial da spin-off e não causar algum tipo de empecilho ao seu desenvolvimento.

\subsection{Etapa 7: Planejamento Financeiro}

Fazem parte dessa etapa de análise: (i) "Plano Financeiro" do Modelo SBA; (ii) "Plano Financeiro" do Modelo Sebrae; (iii) "Investimentos" do Modelo SBA; (iv) "Construção do Orçamento e Planejamento Financeiro" da empresa Flash; (v) "Planejamento Financeiro" da empresa Echo.

O aspecto com maior cobertura entre os modelos teóricos e as intervenções práticas é o que engloba as ferramentas, técnicas e questões financeiras para implantação de uma nova empresa. Tal relevância é devidamente prudente e justificável, pois é nessa etapa do planejamento do negócio onde a verdade vem à tona e os acionistas e demais investidores do negócio efetivamente decidirão se aplicarão recursos para seguir com o projeto.

Entretanto esse caráter decisório de "vai ou não vai" dessa fase do planejamento; foi pouco presente nas duas intervenções. A decisão de implantação do negócio já era "certa"; o cuidado tomado em ambos os negócios - Flash e Echo - foi em realizar projeções com no mínimo 36 meses, para avaliar o desempenho do negócio e como o investimento seria reembolsado. Em ambos os casos, inclusive, os primeiros meses do negócio foram projetados como negativos, justamente para compensar os investimentos mais pesados do início do projeto e também o tempo de amadurecimento do mercado à nova empresa e o que ela oferecia.

É recomendável que o Planejamento Financeiro seja o último ponto a ser elaborado no Plano de Negócios antes do Projeto de Implantação, pois nas etapas anteriores serão expostas a maior parte das necessidades de investimentos e despesas para lançamento do negócio de modo que o Planejamento Financeiro faz a amarração de todas as etapas em termos 
financeiros. Eventualmente, outros custos e despesas surgirão durante a execução do projeto que devem ser atualizados no plano financeiro; tornando esse elemento "um dos mais vivos" do Plano de Negócios.

\subsection{Etapa 8: Planejamento do Projeto}

Fazem parte dessa etapa de análise: (i) "Planejamento do Projeto de Implantação" da empresa Flash; (ii) "Execução do Projeto de Implantação" da empresa Flash; (iii) "Projeto de Implantação" da empresa Echo.

Enquanto o Planejamento Financeiro amarra todos os demais planejamentos e necessidades para implantação do negócio em termos financeiros, o Planejamento do Projeto faz a mesma amarração, porém com enfoque e perspectiva práticos, trazendo à tona as atividades e ações que precisam ser tomadas para efetivamente "tirar a empresa do papel".

Tais atividades e prazos podem tanto dizer respeito às etapas anteriores do plano, como também outros itens não cobertos anteriormente como por exemplo os aspectos jurídicos e burocráticos para abertura da Pessoa Jurídica para a empresa.

A importância do Planejamento do Projeto ser a última etapa do Plano do Negócio se dá por alguns motivos práticos: (i) é preciso que as demais etapas tenham sido concluídas ou estejam minimamente estruturadas, (ii) as regras para compartilhamento de recursos precisam estar bem definidas, pois durante a execução do projeto é esperado que haja um consumo/uso dos recursos da empresa mãe - inclusive, no caso das duas intervenções analisadas, o projeto foi inteiramente executado por recursos da empresa mãe, mesmo que a operação da spin-off seja independente.

\subsection{Adendo A: Plano de Transição}

Faz parte dessa etapa de análise: (i) "Acompanhamento dos Resultados e Transição" do projeto Flash. 
Esse item é opcional e deve ser considerado sempre que seja previsto a transição da spin-off após a sua implantação. Conforme observado no caso do projeto Flash, o líder do projeto de implantação liderou a empresa, já estabelecida, somente até o amadurecimento de seus processos; a partir desse ponto o negócio foi transferido para outro executivo.

Em situações semelhantes a essa, é recomendável ter um plano de transição que considere o histórico de resultados do negócio, o status dos principais processos, projetos e ações, principais indicadores de desempenho e demais informações e dados relevantes para quem for assumir a gestão do negócio.

\subsection{Adendo B: Avaliação Estratégica}

Faz parte dessa etapa de análise: (i) "Construção de Cenários" do Modelo Sebrae; (ii) "Avaliação Estratégica" do Modelo Sebrae.

A análise estratégica mencionada no modelo, refere-se, exclusivamente, à realidade da spinoff, ou seja; não considera de maneira explícita as necessidades da empresa mãe. Torna-se, portanto, opcional e a ser realizada ao final do Plano de Negócios, considerando que nesse estágio é possível realizar uma análise mais profunda de como a spin-off se posiciona estrategicamente e, inclusive, a Avaliação Estratégica pode ser uma ferramenta de suporte para auxiliar na tomada de decisões de investimento ou mesmo retroalimentar definições do modelo de negócio.

Apesar do escopo "reduzido" (focado na spin-off) é recomendável que a Análise Estratégica considere elementos além desse escopo e da matriz SWOT outros aspectos como: análise da Indústria; influências políticas, econômicas, sociais, tecnológicas, ambientais e legais.

\subsection{Adendo C: Produtos e Serviços}

Faz parte dessa etapa de análise: (i) "Produtos e Serviços” do Modelo SBA. 
Esse item não aparenta ser de relevância extrema. Considerando que a sessão de marketing seja bem elaborada, e contemple de forma detalhada os produtos e serviços, esse item pode ser opcional, para o caso de algum tipo de produto e serviço muito específico ou, como é citado pelo SBA, em caso de descrição de patentes ou demais aspectos legais relevantes sobre o produto.

\subsection{Proposta de Modelo de Plano de Negócios para Spin-Off Corporativas}

Com base na análise apresentada entre os itens 5.1 a 5.12, abaixo é apresentado a proposta de modelo de Plano de Negócios.

A proposta, segue a ordem na qual os itens foram apresentados na análise, conforme Tabela a seguir:

Tabela 10 - Itens da Proposta

\begin{tabular}{|c|c|}
\hline 1 & SUMÁRIO EXECUTIVO \\
\hline 2 & ANÁLISE DE MERCADO \\
\hline 3 & MODELO DE NEGÓCIO \\
\hline 4 & MARKETING \\
\hline 5 & ORGANIZAÇÃO E GESTÃO \\
\hline 7 & GOVERNANÇA \\
\hline 8 & PLANEJAMENTO FINANCEIRO \\
\hline
\end{tabular}

O autor entende que essa ordem apresenta uma lógica consistente e evolutiva na construção do Plano de Negócios.

Adiante, segue Ilustração que sintetiza o modelo proposto: 


\begin{tabular}{|c|c|c|c|c|c|c|c|}
\hline $\begin{array}{l}\text { SUMÁRIO } \\
\text { EXECUTIVO }\end{array}$ & $\begin{array}{l}\text { ANÁLISE DE } \\
\text { MERCADO }\end{array}$ & $\begin{array}{l}\text { MODELO DE } \\
\text { NEGÓCIO }\end{array}$ & MARKETING & $\begin{array}{l}\text { ORGANIZAÇÃO E } \\
\text { GESTÃO }\end{array}$ & GOVERNANÇA & $\begin{array}{l}\text { PLANEJAMENTO } \\
\text { FINANCEIRO }\end{array}$ & $\begin{array}{c}\text { PLANEJAMENTO } \\
\text { DO PROJETO }\end{array}$ \\
\hline $\begin{array}{l}\text { O QUE DEVE } \\
\text { CONTEMPLAR } \\
\text { - Descrição do } \\
\text { Negócio } \\
\text { - Motivação } \\
\text { Estratégica (por } \\
\text { que o negócio está } \\
\text { sendo criado?) } \\
\text { - Relação esperada } \\
\text { com a empresa } \\
\text { mãe } \\
\text { - Premissas e } \\
\text { restrições } \\
\text { - Estrutura de } \\
\text { controle (se } \\
\text { haverão sócios) }\end{array}$ & $\begin{array}{l}\text { OQUE DEVE } \\
\text { CONTEMPLAR } \\
\text { - Descrição da } \\
\text { Indústria. } \\
\text { - Análise dos } \\
\text { clientes } \\
\text { - Análise dos } \\
\text { concorrentes } \\
\text { - Análise dos } \\
\text { fornecedores } \\
\text { - Restrições Legais }\end{array}$ & $\begin{array}{l}\text { O QUE DEVE } \\
\text { CONTEMPLAR } \\
\text { - BMG Canvas } \\
\text { - Caso seja um } \\
\text { negócio baseado na } \\
\text { empresa mãe, } \\
\text { utilizar a matriz de } \\
\text { proposta de valor. }\end{array}$ & $\begin{array}{l}\text { O QUE DEVE } \\
\text { CONTEMPLAR } \\
\text { - Criação da marca e } \\
\text { identidade visual } \\
\text { - Detalhamento da } \\
\text { forma de atuação } \\
\text { por canal de } \\
\text { vendas } \\
\text { - Estratégias de } \\
\text { divulgação ao } \\
\text { mercado } \\
\text { - Plano de vendas }\end{array}$ & $\begin{array}{l}\text { O QUE DEVE } \\
\text { CONTEMPLAR } \\
\text { - Desenho dos } \\
\text { processos de } \\
\text { negócio } \\
\text { Se possivel, fozer } \\
\text { Benchmark } \\
\text { - Estrutura de áreas e } \\
\text { pessoas } \\
\text { - Plano de } \\
\text { contratação de } \\
\text { pessoas } \\
\text { - Definição do local } \\
\text { para instalação da } \\
\text { empresa } \\
\text { - Infraestrutura de } \\
\text { funcionamento } \\
\text { - Plano de Compras }\end{array}$ & $\begin{array}{l}\text { OQUE DEVE } \\
\text { CONTEMPLAR } \\
\text { - Definição dos } \\
\text { papéis e } \\
\text { responsabilidades } \\
\text { dos Sócios, alta } \\
\text { direção, executivos } \\
\text { e equipe } \\
\text { - Regras de } \\
\text { compartilhamento } \\
\text { de recursos e } \\
\text { processos com a } \\
\text { empresa mãe. } \\
\text { - Definição da forma } \\
\text { de } \\
\text { acompanhamento } \\
\text { dos resultados do } \\
\text { negócio }\end{array}$ & $\begin{array}{l}\text { O QUE DEVE } \\
\text { CONTEMPLAR } \\
\text { - Dados e } \\
\text { informações das } \\
\text { etapas anteriores } \\
\text { para compor } \\
\text { - Expectativa de } \\
\text { receita } \\
\text { - Expectativa dos } \\
\text { custos e despesas } \\
\text { - Projeção para } 3 \\
\text { anos ou mais } \\
\text { - Indicar a } \\
\text { necessidade de } \\
\text { investimentos }\end{array}$ & $\begin{array}{l}\text { OQUE DEVE } \\
\text { CONTEMPLAR } \\
\text { - Consolidar as } 7 \\
\text { etapas anteriores } \\
\text { - Contemplar tarefas } \\
\text { burocráticas para } \\
\text { abertura da } \\
\text { empresa } \\
\text { - Definir as } \\
\text { atividades, prazos e } \\
\text { responsáveis por } \\
\text { cada entrega } \\
\text { - Definir as formas } \\
\text { de } \\
\text { acompanhamento } \\
\text { do projeto }\end{array}$ \\
\hline
\end{tabular}




\subsection{Avaliação dos especialistas}

Conforme a estrutura prevista para a pesquisa, a proposta de modelo desenvolvida no item 5.13 acima, foi submetida aos dois especialistas para avaliação de sua aderência e possibilidade de aplicação em contextos diferentes aos estudados. Abaixo um resumo da avaliação dos dois especialistas consultados:

\section{$\underline{\text { Prof }^{0} \text { Marcelo Caldeira Pedroso }}$}

Informou que em termos de modelo a proposta está validada. Entretanto, apontou alguns itens ou informações pertinentes que tornariam o modelo mais completo e abrangente.

(i) Maior clareza sobre a decisão de se abrir uma Spin-Off.

O especialista entende que é preciso deixar muito claro a avaliação estratégica da empresa mãe que levou a decisão de investir em uma nova empresa em formato de spin-off.

(ii) Análise das competências da empresa mãe para conduzir a spin-off

É necessário avaliar quais as competências essências necessárias à spin-off e se a empresa mãe as tem em sua estrutura interna ou precisa desenvolver. Além disso, as próprias competências para criação e gestão de um novo negócio devem ser avaliadas pela empresa mãe.

Tal análise deve ocorrer antes da definição do modelo de negócio, e o especialista indica como uma possível ferramenta, o uso da abordagem VBR - Visão Baseada em Recursos ${ }^{8}$.

(iii) Avaliação de Riscos

Essa avaliação de riscos deve considerar dois fatores principais: (a) análise das competências para condução do novo negócio e (b) os investimentos previstos para a implantação. A empresa deve avaliar o quão difícil será para obter/desenvolver as competências necessárias na criação do novo negócio e os investimentos incorridos.

\section{$\underline{\text { Prof }^{\mathrm{o}} \text { Marcos Hashimoto }}$}

O especialista também considerou a proposta validada. Indicou que não identificou inovações na estrutura do mesmo, pois segue o formato padrão de Plano de Negócio. Entretanto, reconheceu os elementos que caracterizam o novo negócio como uma spin-off e, portanto, referendam o modelo como válido.

\footnotetext{
${ }^{8}$ A Visão Baseada em Recursos é uma abordagem de análise estratégica que avalia as vantagens competitivas de uma empresa com base nos recursos disponíveis internamente.
} 
Porém, apresentou ressalvas sobre o uso do BMG Canvas como ferramenta para definição do Modelo de Negócios para spin-offs. Segundo o especialista a amplitude das possibilidades de negócios a ser explorado via spin-off pode ser grande, das quais ele menciona algumas:

(i) novo produto para um mercado já existente

(ii) novo mercado para um produto já existente

(iii) terceirização de uma operação que acontecia apenas internamente

(iv) investimento em um negócio totalmente diferente do que a empresa faz hoje

(v) exploração de uma parte de estrutura ociosa da empresa

(vi) oportunidade de novo negócio que se abre e pode se fechar a qualquer momento

(vii) combater a concorrência

Para cada uma delas, a relação com a empresa mãe pode ser distinta e muito particular, de modo que o BMG Canvas não apresenta profundidade suficiente para acolher tais particularidades. Inclusive, na visão dele se baseando na proposta de modelo, tais particularidades só podem ser respondidas no Sumário Executivo, mediante a exploração da Motivação Estratégica - responder à pergunta: “Por que o negócio está sendo criado? ”-.

O especialista conclui indicando que um Modelo de Negócios ideal para spin-off deve ir além do proposto no BMG Canvas; buscando enfatizar principalmente o tipo de relação entre empresa mãe e a nova empresa. Ele indica inclusive que uma possível solução seria como um "BMG Canvas Dobrado" que indique o grau de aderência de cada elemento do Canvas entre as duas empresas. 


\section{CONCLUSÕES}

\subsection{Proposta de modelo de Plano de Negócios para Spin-Offs Corporativas - ajustada}

Considerando o parecer dos especialistas sobre a proposta desenvolvida, foram promovidos ajustes no modelo original.

\section{Ajuste 1 - Sumário Executivo}

O autor compreendeu que os apontamentos feitos pelos dois especialistas, estão intimamente ligados à decisão estratégica de criação da spin-off e que, eventualmente, elementos da decisão estratégica precisam estar mais explícitos para nortear o Plano de Negócios; sendo um tipo de conexão entre a decisão estratégica da empresa mãe e a implantação da spin-off.

Como o escopo desse trabalho não foi estudar as etapas anteriores à decisão da empresa mãe de criar uma spin-off, não é possível realizar grandes inferências no vasto conteúdo de possibilidades sobre essa decisão estratégica. De modo que, o ajuste realizado no modelo proposto, tem por objetivo provocar os responsáveis pela execução do novo negócio a buscar todas as informações e dados referentes à decisão estratégica tomada pela empresa mãe.

O ajuste consiste na alteração do sumário executivo, expandido a sua função para além de meramente sumarizar informações. No modelo adaptado, o mesmo foi chamado de “Alinhamento Estratégico". Nessa etapa, são apresentadas, além dos itens que já constavam no Sumário Executivo, uma série de perguntas para entender com maior profundidade a decisão de criação da spin-off. Os itens previstos para o Alinhamento Estratégico são:

(i) Motivação Estratégica: Porque o negócio está sendo criado? Alguns exemplos:

a. Novo produto para um mercado já existente?

b. Novo mercado para um produto já existente?

c. Terceirização de uma operação que acontecia apenas internamente?

d. Investimento em um negócio totalmente diferente do que a empresa faz hoje?

e. Exploração de uma parte de estrutura ociosa da empresa?

f. Oportunidade de novo negócio temporário? 
g. Combate a concorrência?

(ii) Ciclo de Vida: qual a perenidade prevista para a spin-off?

(iii) Há similaridade do negócio da empresa mãe com a spin-off?

(iv) O que se espera desse novo negócio em termos de resultado?

(v) Qual a relação que a spin-off terá com a empresa mãe? Alguns exemplos:

a. Compartilhamento de processos?

b. Compartilhamento da cadeia de fornecedores?

c. Compartilhamento de clientes?

d. Uso da marca?

e. Compartilhamento da estrutura administrativa?

f. Uso de patentes em comum?

(vi) Premissas e Restrições

(vii) Estrutura de Controle (sociedade)

Ajuste 2 - Análise de Mercado

O segundo ajuste promovido foi na Análise de Mercado, para incluir a necessidade de análise das competências conforme informado pelo especialista Prof ${ }^{\circ}$ Marcelo Pedroso. Essa etapa foi alterada para "Análise Competitiva", de modo a englobar tanto os aspectos internos como os externos à spin-off.

Ficou estruturado com os seguintes itens:

(i) Ambiente competitivo:

a. Descrição da indústria

b. Restrições legais

c. Barreiras de entrada e saída

(ii) Análise Externa

a. Clientes

b. Concorrentes, atuais e potenciais.

c. Fornecedores

(iii) Análise Interna (VBR)

a. Recursos chave à implantação e posterior operação da spin-off

Ajuste 3 - Planejamento Financeiro 
O ajuste no Planejamento Financeiro foi a inclusão de uma etapa final que é a "Avaliação de Riscos”. Tal avaliação deve levar em consideração informações de todas as etapas anteriores do Plano de Negócios, porém com inferências diretas da Avaliação Estratégica e da Análise Competitiva.

Esses ajustes, especialmente os dois primeiros, permitirão que questões estratégicas e cruciais ao bom planejamento da spin-off sejam efetivamente expostas e estruturadas, orientando todos os demais passos de forma mais consistente. De modo inclusive que a definição do modelo de negócios terá elementos para uma construção robusta.

Quanto à ferramenta para estruturação do modelo de negócios, optamos por manter o $B M G$ Canvas, porém recomendo que a ferramenta não seja utilizada de maneira isolada, ou mesmo de forma "estática". É preciso que a haja uma reflexão por parte dos responsáveis pela implantação do novo negócio para entender e endereçar as particularidades da spin-off a ser implantada.

Outro argumento que permite a manutenção do BMG Canvas, é o fato do mesmo dispor de informações que são cruciais ao funcionamento de qualquer negócio; de uma maneira visualmente simples. Como um dos objetivos com o Plano de Negócios proposto é contribuir com a prática empreendedora, entendemos que esse modelo pode ajudar à empresas, empresários e empreendedores corporativos que não tenham grande domínio do tema de administração de empresas.

De todo modo, a completa aplicabilidade do BMG Canvas e mesmo as melhores alternativas para construção de Modelos de Negócio para spin-offs corporativas serão melhor discutidos na seção "Sugestão para Pesquisas Futuras" adiante nessa conclusão.

Considerando os ajustes e comentários acima, apresentamos, nas Ilustrações a seguir, o modelo proposto atualizado com um guia simplificado de preenchimento. 


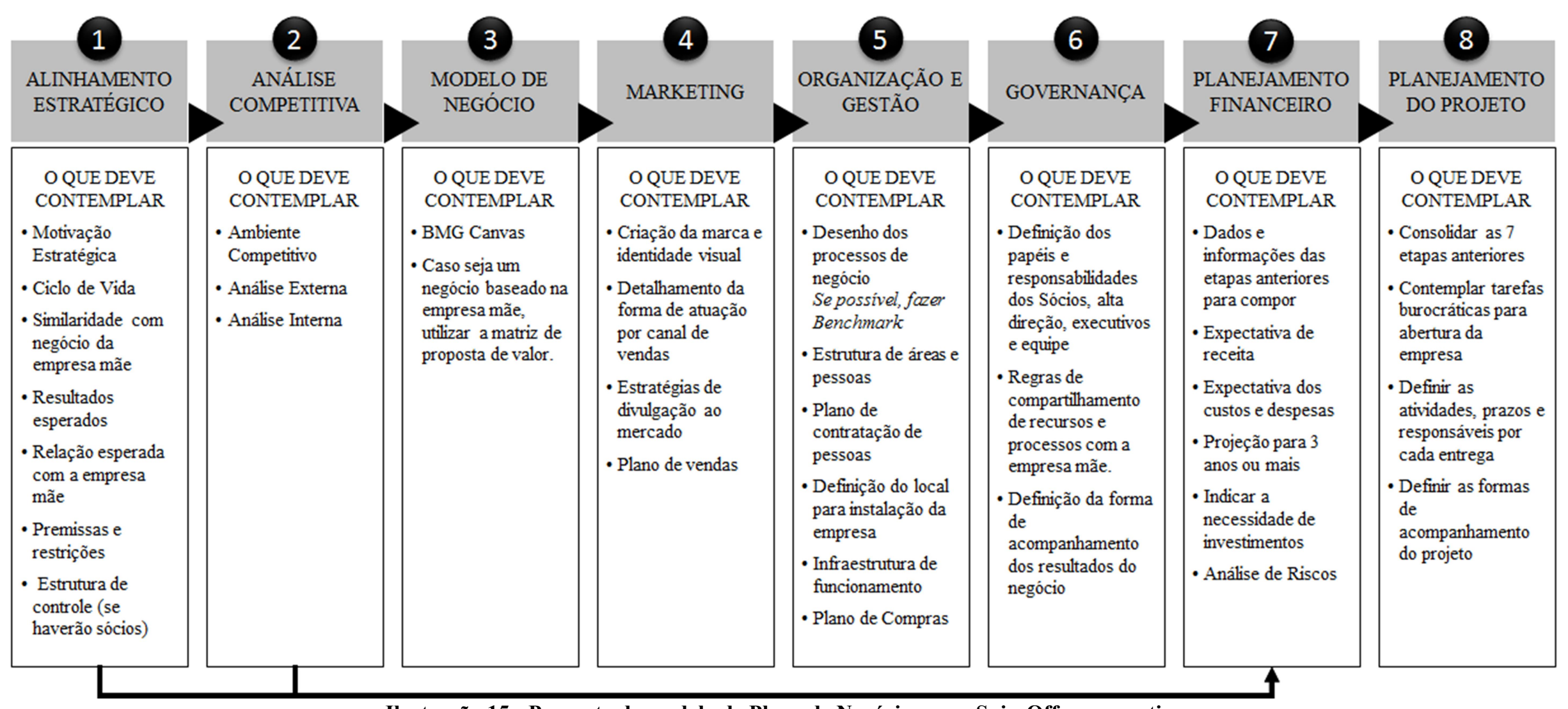

Ilustração 15 - Proposta de modelo de Plano de Negócios para Spin-Offs corporativas 


\section{Alinhamento Estratégico}

Motivação Estratégica: Porque esse negócio está sendo criado? Abaixo, alguns exemplos:

- Novo produto para um mercado já existente?

- Novo mercado para um produto já existente?

- Terceirização de uma operação que acontecia apenas internamente?

- Investimento em um negócio totalmente diferente do que a empresa faz hoje?

- Exploração de uma parte de estrutura ociosa da empresa?

- Oportunidade de novo negócio temporário?

- Combate a concorrência?

Ciclo de Vida: Qual o tempo de funcionamento para esse negócio?

- Temporário (por quanto tempo?)

- Perene?

Similaridade: Quais as semelhanças com a empresa mãe?

- Modelo de Negócio?

- Postura estratégica?

- Forma de trabalho?

- Nenhuma?
Resultado: O que se espera com esse novo negócio?

- Faturamento?

- Ganho de Mercado?

- Aumento de relevância junto a fornecedores?

- Atrair talentos?

Relação Esperada com a empresa mãe

- Compartilhamento de processos?

- Compartilhamento da cadeia de fornecedores?

- Compartilhamento de clientes?

- Uso da marca?

- Compartilhamento da estrutura administrativa?

- Uso de patentes em comum?

\section{Premissas e Restrições}

Devem ser descritas as principais regras do que deve ou não deve ser considerado no negócio, bem como as premissas estabelecidas para a sua concepção.

\section{Estrutura de Controle}

Indicar como será a estrutura societária da empresa. Se será apenas a empresa mãe ou terão outros sócios.

Ilustração 16 - Guia de preenchimento: Alinhamento Estratégico 


\section{Análise Competitiva}

\section{Ambiente Competitivo}

Descrição da indústria: Descrever a estrutura da cadeia; identificação dos participantes e a sua função. Além disso, a maturidade da indústria, sua taxa de crescimento, perspectiva de futuro e condições de entrada e saída.

Restrições Legais: Atenção a eventuais restrições legais para atuação no mercado. No caso de existir, estudar como atender e qual a influência disso em padrões, processos, recursos e investimentos.

Barreiras de Entrada: mapear outras barreiras de entrada, como capital inicial necessário, tecnologia e mesmo eventuais protecionismos governamentais.

\section{Análise Interna (VBR)}

Visão Baseada em Recursos: Identificar na estrutura interna da empresa mãe, os recursos críticos para implantação da spin-off e sua posterior operação. Em caso de não os possuir, indicar como serão desenvolvidos / adquiridos. É importante explicar porque tais recursos são estratégicos para a competitividade da empresa.

\begin{abstract}
Análise Externa
Análise dos Clientes: Identificação do mercado a ser explorado, seu tamanho e potencial de crescimento. Definição do público alvo e o perfíl dos clientes, bem como a sua representatividade de no mercado e quanto a empresa pretende atingir com o negócio.

Análise dos Concorrentes: Mapear os principais concorrentes, as suas fortalezas e fraquezas, diferenciais competitivos e como eles afetam a relação com os clientes. Identificação dos produtos e serviços oferecidos e os preços de mercado. Atenção à padrões exigidos na oferta, bem como eventuais barreiras de entrada. Mediante o entendimento da concorrência avaliar qual o espaço existente no mercado e como atingi-lo.

Análise dos Fornecedores: dentificar os principais fornecedores, a estrutura de relação deles com a indústria, mercado e competidores. Verificar os padrões de qualidade capacidade de fornecimento, bem como os insumos e serviços críticos.
\end{abstract}




\section{Modelo de Negócio (1 de 2)}

ATENÇÃO: É de suma importância que o responsável pela implantação da spin-off tenha executado de maneira detalhada os dois passos anteriores, de modo que tenha elementos consistentes para construção do modelo de negócio.

Apresentamos em caráter de sugestão duas ferramentas para elaboração do modelo de negócio; porém cabe ao responsável avaliar as particularidades do novo negócio, especialmente no tocante ao alinhamento estratégico, para decidir se as sugestões são aderentes à sua realidade.

Ferramentas BMG CANVAS e MATRIZ DE PROPOSTA DE VALOR (essa segunda no caso da spin-off se basear no modelo de negócios da empresa mãe).

Abaixo a Matriz de Proposta de Valor e na próxima página o $\underline{B M G \text { Canvas }}$

\section{Eliminar}

Que elementos da proposta de valor da empresa mãe precisam ser eliminados do negócio para que a proposta de valor da spin-off seja atrativa ao segmento de clientes almejado?

\section{Reduzir}

Que elementos da proposta de valor da empresa mãe precisam ser reduzidos ou minimizados para que a proposta de valor da spin-off seja atrativa ao segmento de clientes almejado?

\section{Elevar}

Que elementos da proposta de valor da empresa mãe precisam ser ampliados ou melhorados para que a proposta de valor da spin-off seja atrativa ao segmento de clientes almejado?

\section{Criar}

O que é necessário ser criado para que a proposta de valor da spin-off seja atrativa ao segmento de clientes almejado? 


\section{Marketing}

\section{Criação da marca e identidade visual}

Definição da marca, considerando a sua aderência ao mercado alvo, diferenciação da concorrência e demais aspectos relevantes. Verificação se a marca está disponível comercialmente, para uso na internet e em redes sociais; registrá-la em nome da empresa.

\section{Detalhamento da forma de atuação por canal de vendas}

Definir a utilização dos canais de vendas; precificação, mix de produtos, priorização e a participação esperada para canal. Considerar o custo de venda por canal e, caso envolva canal de venda físico, as questões relacionadas ao local, como acesso, segurança, layout de loja, etc.

\section{Estratégias de divulgação ao mercado}

Definir as campanhas de divulgação ao mercado, quais os meios, tipo de propaganda e custos envolvidos. Importante considerar estratégias específicas para as redes sociais, bem como internet.

\section{Plano de vendas}

Definição das metas de vendas considerando as informações acima, a expectativa de receita para o negócio, bem como a estrutura de remuneração dos canais de vendas.

Ilustração 20 - Guia de Preenchimento: Marketing 


\section{Organização e Gestão}

\section{Desenho dos processos do negócio}

Descrever o passo-a-passo das atividades mais relevantes para o negócio. Estabelecer os padrões de qualidade esperados e acordos de nível de serviço. Se possível, fazer benchmark das melhores práticas de mercado. Considerar a relação de compartilhamento com a empresa mãe.

\section{Estrutura de áreas e pessoas}

Definição do organograma da empresa. Considerar a relação de compartilhamento com a empresa mãe.

\section{Plano de Contratação de pessoas}

A partir do organograma indicar o perfil dos funcionários necessários, salários e benefícios envolvidos. Indicar a evolução do quadro ao longo do tempo e necessidade de capacitação.

\section{Local de Instalação da empresa}

Definir onde a empresa será instalada. Pontos de atenção: aluguel, condomínio, acesso para funcionários, clientes e fornecedores, aspectos tributários, licenças de funcionamento, infraestrutura da região e necessidade de segurança particular.

\section{Infraestrutura de funcionamento}

Definição de estrutura de telefonia, internet, preparação do imóvel para maquinas e equipamentos, contrato com prestadores de serviço públicos, eventuais intervenções no entorno do imóvel.

\section{Plano de Compras}

A partir da necessidade de infraestrutura planejar o prazo e valores com compras, investimentos e gastos para montagem da operação. 


\section{Governança}

\section{Papéis e Responsabilidades}

Descrever qual a atribuição e forma de atuação dos principais gestores e executivos da spin-off, bem como de pessoas chave na estrutura da empresa mãe que tenham relação direta com a operação da nova empresa. Devem ser considerados também a responsabilidade de eventuais sócios.

Mencionar níveis de alçada financeira e também de tomada de decisão. Essas regras devem ser estabelecidas em comum acordo com os principais envolvidos, ser documentada e compartilhada.

\section{Regras de compartilhamento com a empresa mãe}

Definição do organograma da empresa

\section{Acompanhamento do Negócio}

Definição dos principais indicadores de acompanhamento, relatórios, periodicidade de avaliação e métricas para suportar a tomada de decisão como negócio em operação. 


\section{Planejamento Financeiro (1 de 2)}

Com base nas informações dos 6 passos anteriores, criar um plano com projeção para no mínimo 36 meses (recomendado) que contemple: expectativas de receita, custos e despesas, e eventuais investimentos externos.

Abaixo uma lista de referência com exemplos de itens que podem constar no planejamento financeiro. É fundamental que o responsável pelo planejamento da spin-off se limite aos exemplos listados, sendo necessário avaliar quais outros pontos pertinentes à empresa precisam ser considerados. Como por exemplo as questões tributárias, que diferem muito entre cada tipo de negócio, a região de implantação e mesmo a região dos clientes pretendidos. É altamente recomendável a contratação de um especialista tributário para auxiliar nessa etapa.

RECEITA
Todas as variáveis relacionadas a vendas
e geração de caixa
Direta
Quantidade
Preço
Custo venda
Receita
Rentabilidade\%
Impostos sobre vendas
Receita Líquida
Indireta
Bônus por performance
Verbas de publicidade
Patrocínios

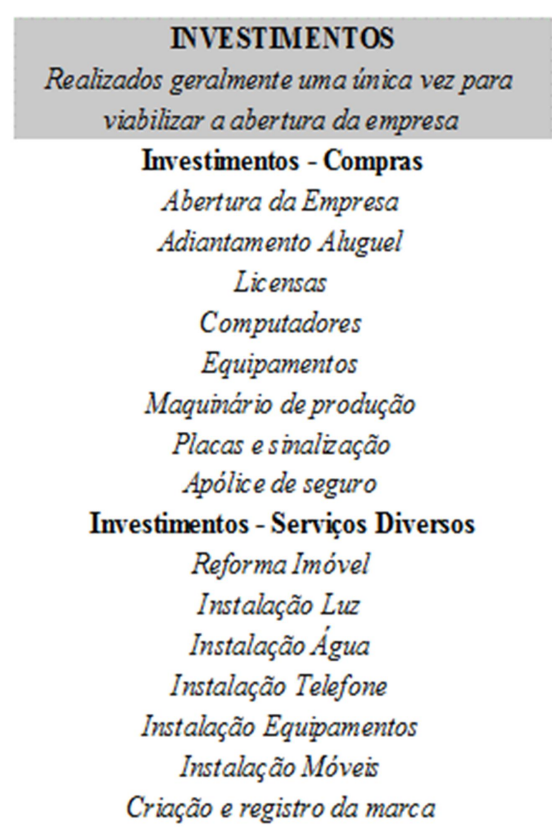
DESPESAS RECORENTES
Gastos necessários para manter a empresa funcionando Salários
Folha de Pagamentos Beneficios
Bônus e variáveis
Custo Variável
Custos de produção
Custo de matéria prima
Custos Financeiros (variáveis)
Taxas bancárias
Taxa Venda no Cartáo de Crédito
Antecipação Recebimento
Suporte e Consultoria
Jurídico
Contadabilidade
Marketing
Ações de Morketing
Despesas com representação

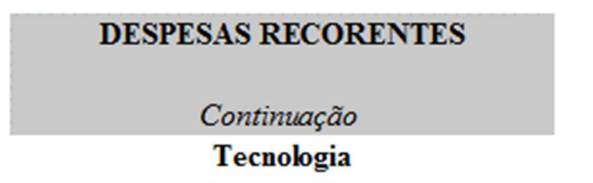

Desenvolvimento de sistemas Licenças

Manutenção de sistema

$$
\text { Help Desk }
$$

Despesas Recorrentes

Aluguel escritorio

Suporte administrativo Manutenção

Correios

Água

Luz

Materiais de Escritório

Ilustração 23 - Guia de preenchimento: Planejamento Financeiro (lâmina 1 de 2) 


\section{Planejamento Financeiro (2 de 2)}

\section{Análise de Riscos}

Após a definição do planejamento financeiro, onde ficará definido a necessidade de investimentos, deve-se realizar uma análise de riscos que considere além dos aspectos financeiros, as questões estratégicas e de competitividade.

A análise deve se considerar os riscos envolvidos na implantação do negócio, a capacidade de execução e de competir num nível condizente com as expectativas do negócio.

É portanto uma validação da decisão de investimento, pode ser que nessa etapa, após decorrido o aprofundamento no plano para criação da spin-off os executivos da empresa mãe, optem por descontinuar o projeto da Spin-off ou promover ajustes para adequar a relação risco x retorno.

Ilustração 24 - Guia de preenchimento: Planejamento Financeiro (lâmina 2 de 2) 


\section{Planejamento do Projeto (1 de 2)}

Essa etapa consolida todas as informações dos 7 passos anteriores e as organiza em formato de projeto, com tarefas e atividades a serem executadas, responsáveis e prazos. Pode ser utilizada qualquer técnica ou metodologia de projetos que o responsável pela implantação da spin-off ou a empresa mãe tenha domínio ou preferência.

Na próxima página, segue modelo de referência com a Estrutura Analítica de um projeto genérico para implantação de uma spin-off. Novamente, cabe ao responsável pela implantação avaliar a melhor estrutura do projeto que se adeque a sua realidade.

Ilustração 25 - Guia de Preenchimento: Planejamento do Projeto (lâmina 1 de 2) 


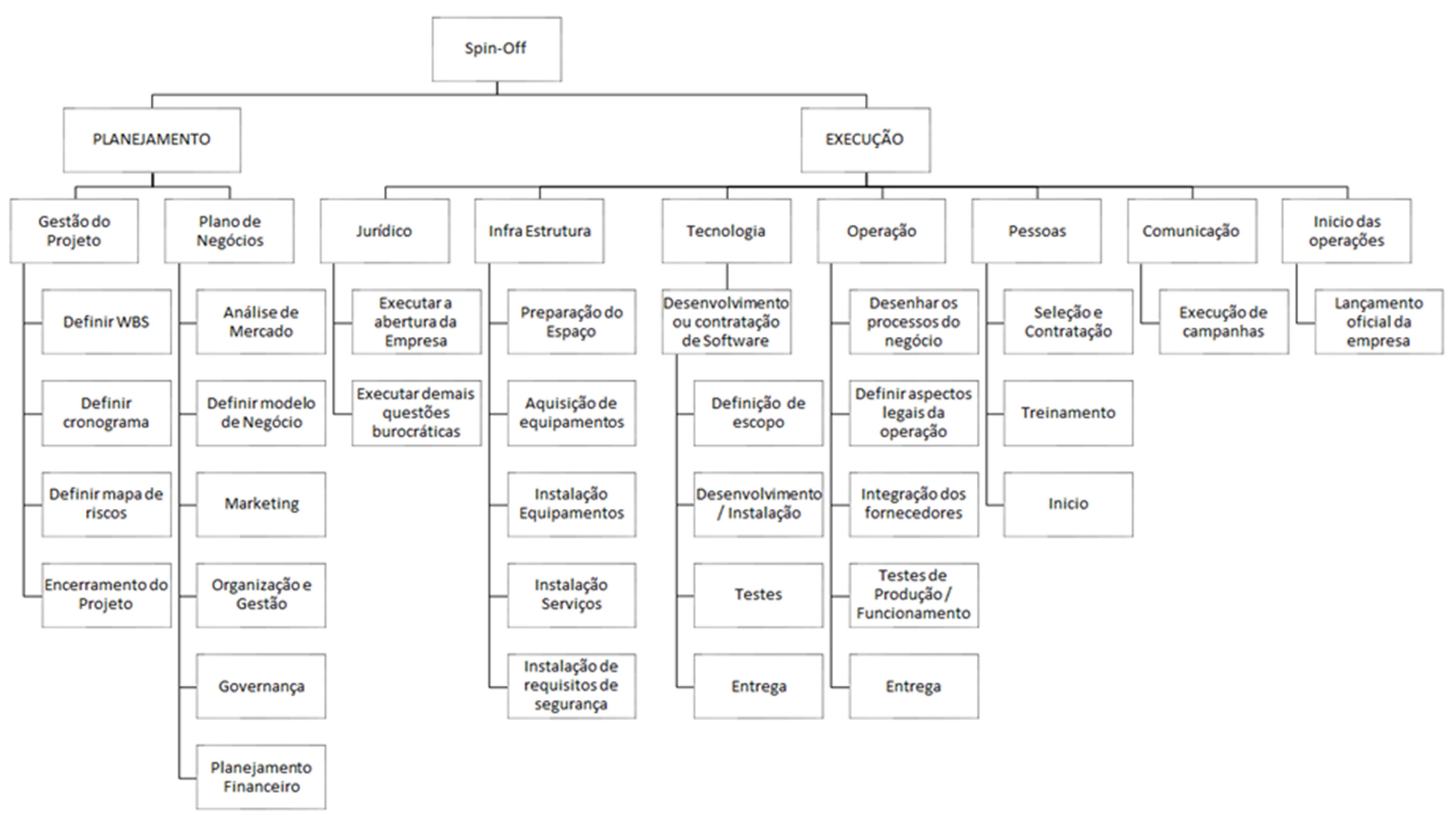

Ilustração 26 - Guia de Preenchimento: Planejamento do Projeto (lâmina 2 de 2) 


\subsection{O estudo de spin-offs corporativas}

Dentre as muitas formas de empreendedorismo corporativo, talvez a estruturação de uma spin-off seja o fenômeno que mais se aproxima do empreendedorismo de pessoa física, onde indivíduos corajosos e dispostos a correr riscos, empenham seus esforços na concepção de um novo negócio e a consequente estruturação de uma empresa para colocar a ideia na prática.

Estudos sobre spin-offs corporativas tem crescido, porém ainda não é um tema tão atrativo aos pesquisadores como por exemplo: modelos de inovação, startups ou mercado digital.

Eventualmente esse desinteresse parta das próprias empresas que investem nesse tipo de negócio sem buscarem ampliar seu conhecimento sobre o fenômeno. Por vezes tratando esse tipo de iniciativa como apenas mais um projeto dentro do seu portfólio. Entretanto, acredito que o amadurecimento do entendimento sobre o tema partirá de pequenas contribuições como a que esse trabalho entrega

Do ponto de vista teórico, posso afirmar que a teoria tem se expandido exatamente dessa forma, pouco a pouco novos trabalhos surgem agregando uma peça a mais de conhecimento em campos específicos do vasto tema que são as spin-offs corporativas.

É notável por exemplo, que a base de conhecimento sobre spin-offs acadêmicas é mais madura e plural; eventualmente, a necessidade de encontrar formas mais eficientes de transferir o conhecimento da academia para o mercado - sendo, portanto, as spin-offs uma forma para tal - impulsionem a produção nesse sentido.

Quando olhamos, porém, para o âmbito das spin-offs corporativas, o volume e amplitude das publicações é mais limitado. Uma das possíveis limitações é a dificuldade dos pesquisadores em obter acesso a informações sobre as iniciativas desse tipo de negócio pois são informações sensíveis e estratégicas para as empresas envolvidas, de modo que, por receio, não colaboram com as pesquisas. Mesmo em casos de spin-off de empresas com capital aberto as informações pertinentes aos pontos críticos - como por exemplo as regras de relacionamento com a empresa mãe - não são disponíveis ou de fácil acesso. 
Tal limitação foi experimentada na execução desse trabalho. Por duas vezes na tentativa de conseguir entrevistas com executivos que conduziram processos de spin-off corporativas, o autor não obteve êxito; sendo que em conversa informal com um deles, foi exposto que são detalhes estratégicos para o negócio, e, portanto, inviáveis de serem compartilhados.

Eventualmente com a expansão desse tipo de empreendimento e maior entendimento da necessidade de trata-lo de forma específica pode auxiliar nos futuros estudos sobre o tema.

\subsection{Aspectos críticos de Spin-Offs corporativas}

A experiência do autor mostrou que alguns aspectos de spin-offs corporativas são críticos para a sua implantação.

O principal ponto é a relação de compartilhamento com a empresa mãe. Principalmente se não há uma regra clara para arbitrar essa utilização, de modo que houve uma notável evolução sobre esse tema entre os dois casos estudados. Não só relacionado às regras de uso dos recursos, mas também de alçada e estrutura de poder entre a empresa mãe e a spin-off.

Infelizmente não tivemos a oportunidade de estudar outras empresas para verificar qual o comportamento dessa questão. Entretanto, o fato de um dos principais temas de produção sobre spin-off corporativas é justamente a relação com a empresa mãe; aponta um indício da importância e criticidade desse tema.

Outro aspecto crítico é uma eventual limitação dos dirigentes das empresas mãe, enquanto estruturam uma spin-off. Essa limitação pode se materializar de duas formas principais: (i) ao negligenciar um olhar estratégico apurado sobre questões de competitividade, mercado, concorrência, etc. Ou seja, "acreditar apenas no seu feeling” (ii) Ao tratar a criação da spin-off como um projeto comum, ou que não precisa de um tratamento e estrutura de execução específico. 
Novamente, pode ser uma limitação da amostra que abordou dois casos dentro da mesma empresa. Porém, o segundo caso contava com uma segunda companhia também no papel de empresa mãe, e mesmo os dirigentes dessa empresa apresentaram semelhante comportamento.

\subsection{Sugestões para pesquisas futuras}

Primeiramente é preciso reforçar que o modelo proposto não passou por uma etapa de uso prático. De modo que uma possível forma de dar continuidade ou aprofundar o conhecimento sobre o tema de Planos de Negócios para spin-offs corporativas pode ser o uso do Modelo sugerido, com acompanhamento dos resultados e propostas de alterações, melhorias e complementos ao que foi aqui colocado. Uma outra forma de dar continuidade a esse tema, é o entendimento do fenômeno com outras empresas dispostas a contribuir com a evolução do conhecimento.

Especificamente sobre os Modelos de Plano de Negócios estudados, fica latente a necessidade de as agências de fomento expandirem sua atuação para suportar ou auxiliar os empreendedores corporativos que desejam porventura seguirem com a estratégia de abertura de um novo negócio por meio de uma spin-off.

Ambos os modelos estudados, não trazem conteúdo específico para esse tipo de empreendimento. Por mais que negócios pequenos - que é justamente o público atendido por Sebrae e SBA - tenham menor propensão a expandir mediante a criação de uma nova empresa, as agências de fomento precisam estar preparadas para suportar esses empresários, por serem esses eventualmente os que mais precisem de conhecimento e suporte.

Por fim e não menos importante, outros temas que podem ser explorados inerentes à spin-offs corporativas são: (i) estudo de modelos de negócio, conforme mencionado pelo especialista Prof $f^{o}$ Marcelo Hashimoto, é preciso explorar o tema, para além do trivial BMG Canvas; (ii) Comparação do desempenho das spin-offs com empresas "normais" e (iii) Desempenho de empresas mãe que investiram em projetos de spin-off. 


\section{REFERÊNCIAS}

\section{BANKS, Alex. Número Recorde de Brasileiros Utiliza a Web para Planejar Viagens e}

Fazer Reservas. comScore MediaMetrix. Acesso em Setembro 2012.

BIG DATA, (2016). Big Data - O que é e por que é importante. SAS. Disponível em: $<$ http://www.sas.com/pt_br/insights/big-data/what-is-big-data.html $>$. Acesso em: 22/07/2016.

CAPES - Fundação Coordenação de Aperfeiçoamento de Pessoal de Nível Superior. Mestrado Profissional: O que é?, Brasília, 2014. Disponível em: $<$ http://www.capes.gov.br/avaliacao/sobre-a-avaliacao/mestrado-profissional-o-que-e >. Acesso em: 03/06/2016.

CLARYSSE, Bart; WRIGHT, Mike; LOCKETT, Andy; VAN DE VELDE, Els; VOHORA, Ajay. Spinning out new ventures: a typology of incubation strategies from European research institutions. Journal of Business Venturing, v. 20, n. 2, p. 183-216, 2005.

CLARYSSE, Bart; WRIGHT, Mike; VAN DE VELDE, Els. Entrepreneurial Origin, Technological Knowledge, and the Growth of Spin-Off Companies. Journal of Management Studies, v. 48, n. 6, p. 1420-1442, 2011.

COZZI, Afonso O.; FILION, Louis J.; DOLABELA, Fernando; BORGES, Candido; LIMA, Edmilson de O.; JUDICE, Valeria M. M.; MENDES, Daniel M.; DAPIEVE, Luana de A.. Projeto Spin-offs Corporativos (RP 0609 - Relatório de Pesquisa/2006), Centro Alfa, Núcleo de Empreendedorismo, Nova Lima: Fundação Don Cabral, 2006.

FERRAZ, Janaynna M.; TEIXEIRA, Rivanda M. A Criação de Spin-offs Corporativos: Analisando a Relação da Organização-mãe e Spin-off. In: VIII ENCONTRO DE ESTUDOS EM EMPREENDEDORISMO E GESTÃO DE PEQUENAS EMPRESAS - EGEPE, 2014, Goiânia. Anais... Goiânia, 2014.

GARVIN, David A. Spin-offs and the new firm formation process. California Management Review, v. 25, n. 2, p. 3-20, 1983.

GIL, Antônio C. Como elaborar projetos de pesquisa. 4. ed. São Paulo: Atlas, 2002.

GOLDENBERG, Mirian. A arte de pesquisar: Como fazer pesquisa qualitativa em Ciências Sociais. Rio de Janeiro: Record, 2011.

GOOGLE. Google AdWords. Como funciona, 2016a. Disponível em: $<$ https://www.google.com.br/adwords/>. Acesso em: 19/07/2016.

Google Analytics. Como funciona, 2016b. Disponível em:

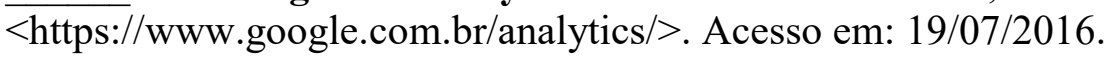


KIM, W. Chan; MAUBORGNE, Renee. Blue ocean strategy: How to Create Uncontested Market Space and Make the Competition Irrelevant. Boston: Harvard Business School Press, 2005 .

KLEPPER, Steven. Spinoffs: A review and synthesis. European Management Review, v. 6, n. 3, p. 159-171, 2009.

KRAKAUER, Patricia V. de C. Ensino de empreendedorismo: estudo exploratório sobre a aplicação da teoria experiencial. São Paulo, 2014. Tese (Doutorado em Administração) Programa de Pós-Graduação em Administração, Faculdade de Economia, Administração e Contabilidade da Universidade de São Paulo, São Paulo, 2014.

KRAKAUER, Patricia V. de C.; MARQUES, Jane A.; ALMEIDA, Martinho I. R. Mestrado Profissional em Administração: diretrizes na elaboração dos projetos. In: XXXIX Encontro da ANPAD - ENANPAD, 2015, Belo Horizonte. Anais... Belo Horizonte, 2015.

LUC, Danielle; FILION, Louis J.; FORTIN, Paul-Arthur. Spin-off de empresas: em direção a novas formas de práticas empresariais. (Guia). Montreal: École des Hautes Études Commerciales, 2002.

MARTINS, Gilberto. D. A.; THEÓFILO, Carlos. R. Metodologia da Investigação Científica para Ciências Sociais Aplicadas. São Paulo: Atlas, 2009.

MUSTAR, Philippe; RENAULT, Marie; COLOMBO, Massimo G.; PIVA Evila; FONTES, Margarida; LOCKETT, Andy; WRIGHT, Mike; CLARYSSE, Bart; MORAY Nathalie. Conceptualising the heterogeneity of research based spin-offs: a multi-dimensional taxonomy. Research Policy, v. 35, n. 2, p. 289-308, 2006.

OECD - ORGANISATION FOR ECONOMIC CO-OPERATION AND DEVELOPMENT. Promoting Entrepreneurship and innovative SMEs in a Global Economy: Towards a More Responsible and Inclusive Globalization. Istanbul, Turkey, 2004.

OSTERWALDER, Alexander; PIGNEUR, Yves. Business model generation: a handbook for visionaries, game changers, and challengers. New Jersey: John Wiley \& Sons, 2010.

PARHANKANGAS, Annaleena; ARENIUS, Pia. From a corporate venture to an independent company: a base for a taxonomy for corporate spin-off firms. Research Policy, v. 32, n. 3, p. 463-481, 2003.

PORTER, Michael. E. From competitive advantage to corporate strategy. In: GOOLDS, Michael; LUCHS, Khatleen S. (Eds.). Managing the multibusiness company: Strategic issues for diversified groups, p. 285-314, London and New York: Routledge, 1996.

ROBERTS, E. B.; BERRY, C. A. Entering new business: selecting strategies for success [Working Paper No $1492-83$ - 84]. Sloan School of Management, Cambridge, 1984. 
SBA - U. S. SMALL BUSINESS ADMINISTRATION. Starting \& Managing, 2016. Disponível em: <https://www.sba.gov/starting-business/write-your-businessplan?interiorpage2015>. Acesso em: 10/03/2016.

SEBRAE - SERVIÇO BRASILEIRO DE APOIO ÀS MICRO E PEQUENAS EMPRESAS. Como elaborar um plano de negócios. Brasília, 2013.

THORNBERRY, Neal E. Corporate entrepreneurship: Teaching managers to be entrepreneurs. Journal of Management Development, v. 22, n. 4, p. 329-344, 2003.

VAN DE VELDE, Els; CLARYSSE, Bart. A Model of Antecedents and Characteristics of Corporate Spin-offs [Working Paper No 2006 - 389]. Faculteit Economie em Bedrijfskunde, Amsterdam, 2006.

YIN, Robert K. Estudo de Caso: planejamento e métodos. 3. ed. Porto Alegre: Bookman, 2010 . 
ANEXO

ANEXO A - Resposta especialista: Prof ${ }^{\circ}$ Marcos Hashimoto 
ANEXO A - Resposta especialista: Prof ${ }^{\mathfrak{a}}$ Marcos Hashimoto

\section{Pesquisa MPE - Gabriel Paiva - Validação com Especialista}

$\begin{aligned} & \text { Marcos Hashimoto }< \\ & \text { To: Gabriel Paiva < } \\ & \text { Olá Gabriel, }\end{aligned}$
@gmail.com>

O seu modelo é interessante e me despertou várias reflexões com base em minha experiência em empreendedorismo corporativo.

Em primeiro lugar, preciso dizer que é um proposta inovadora e bem vinda para o meio acadêmico, mas principalmente para o meio corporativo.

Em segundo lugar, preciso dizer também, pelos mesmos motivos, que é uma proposta ousada para um mestrado profissional. A amplitude e ambição da proposição de um modelo como este poderia perfeitamente fazer parte de um projeto de doutorado. Espero que você considere sua titulação como apenas parte de um projeto maior no qual você poderá desenvolver todo o potencial deste modelo como uma tese de doutorado. De qualquer maneira, mantendo o escopo para um mestrado profissional, considere minhas contribuições pertinentes apenas no que você poderá fazer dentro do seu prazo.

Com relação à estrutura como um todo, de fato, não é muito inovador, pois é a estrutura típica de um plano de negócio. A novidade aqui é a inserção de alguns elementos que caracterizam o novo negócio como uma spin off de uma empresa mãe. Neste sentido, ressaltando os pontos que representam estes diferenciais, você está coberto de razão e considere o modelo validado.

Por outro lado, não considero que a spin off possa ser vista como um simples negócio que pode ser mapeado desta forma, vou explicar porque.

Para começar, o BMG Canvas. Eu tenho tentado evitar usar o modelo em cursos de Administração, pela sua superficialidade. O modelo é extremamente útil para qualquer pessoa que vai montar um negócio e que não tenha esta formação específica em Administração, justamente pela sua simplicidade de compreensão. No entanto, se estamos falando de um universo no qual se estimula a profundidade, me parece que a ferramenta não se encaixa, a não ser que a própria ferramenta seja o objeto de estudo, o que não é o seu caso.

Na verdade, no seu caso, a coisa até se complica um pouco mais, pois muito pouco ou eu diria praticamente nada no BMG Canvas caracteriza uma spin off corporativa. É como tentar encaixar um círculo dentro de um quadrado.

Para entender minha visão, procure compreender os diversos tipos de spin offs que podem existir, para citar alguns exemplos apenas:

- Pode ser um novo produto para um mercado já existente

- Pode ser um novo mercado para um produto já existente

- Pode ser uma terceirização de uma operação que acontecia apenas internamente

- Pode ser um investimento em um negócio totalmente diferente do que a empresa faz hoje (CVC)

- Pode ser uma forma de explorar uma parte de estrutura ociosa da empresa

- Pode ser uma oportunidade de novo negócio que se abre e pode se fechar a qualquer momento

- Pode ter sido apenas uma forma de combater a concorrência e fechar a qualquer momento

Para cada tipo de spin off, a ligação com a empresa mãe pode ser completamente diferente e nenhuma destas formas diferentes pode ser mapeada no BMG Canvas, a única forma de ver isso é por meio da primeira pergunta que você faz no sumário executivo, a motivação estratégica, mas responder este item está muito longe de demonstrar as particularidades de cada modelo de negócio diferente que pode surgir e os modelos que podem surgir daqui podem ser completamente diferentes dos que Osterwalder sugere em sua obra, pois representa variações diversas da resposta à outra pergunta do sumário executivo: Relação esperada com a empresa mãe.

Desta forma, um bom modelo de spin off deve quebrar este paradigma existente do canvas e buscar um formato que melhor caracterize a aderência entre a spin off e a empresa mãe, por exemplo, vai compartilhar apenas a infraestrutura logística? Vai compartilhar apenas a marca da empresa para alavancar o surgimento de outra marca de produto? Vai ser um negócio totalmente diferente compartilhando apenas a estrutura administrativa? As configurações são inúmeras. É como se o novo modelo fosse um BMG Canvas dobrado, mostrando o grau de aderência de cada elemento do canvas entre as duas partes, a spin off e a empresa mãe, ou algo parecido.

Bem, não tenho com detalhar muito esta ideia, mas obviamente não é algo que vale a pena detalhar em um projeto de mestrado, portanto, não é objetivo meu ir a fundo deste conceito, mas se você entendeu um pouco a diferença, é suficiente.

Se quiser falar mais a respeito, podemos marcar um call.

Abs

Marcos 